\title{
Data composites of airborne observations of tropospheric ozone and its precursors
}

\author{
Louisa K. Emmons, ${ }^{1}$ Didier A. Hauglustaine, ${ }^{2}$ Jean-François Müller, ${ }^{3}$ Mary \\ Anne Carroll, ${ }^{4}$ Guy P. Brasseur, ${ }^{1,5}$ Dominik Brunner, ${ }^{6}$ Johannes Staehelin, ${ }^{6}$ \\ Valerie Thouret, ${ }^{7}$ and Alain Marenco ${ }^{7}$
}

\begin{abstract}
Tropospheric data from a number of aircraft campaigns have been gridded onto global maps, forming "data composites" of chemical species important in ozone photochemistry. Although these are not climatologies in the sense of a long temporal average, these data summaries are useful for providing a picture of the global distributions of these species and are a start to creating observationsbased climatologies. Using aircraft measurements from a number of campaigns, we have averaged observations of $\mathrm{O}_{3}, \mathrm{CO}, \mathrm{NO}, \mathrm{NO}_{x}, \mathrm{HNO}_{3}, \mathrm{PAN}, \mathrm{H}_{2} \mathrm{O}_{2}, \mathrm{CH}_{3} \mathrm{OOH}$, $\mathrm{HCHO}, \mathrm{CH}_{3} \mathrm{COCH}_{3}, \mathrm{C}_{2} \mathrm{H}_{6}$, and $\mathrm{C}_{3} \mathrm{H}_{8}$ onto a $5^{\circ}$ latitude by $5^{\circ}$ longitude horizontal grid with a $1-\mathrm{km}$ vertical resolution. These maps provide information about the distributions at various altitudes, but also clearly show that direct observations of the global troposphere are still very limited. A set of regions with $10^{\circ}-20^{\circ}$ horizontal extent has also been chosen wherein there is sufficient data to study vertical profiles. These profiles are particularly valuable for comparison with model results, especially when a full suite of chemical species can be compared simultaneously. The $\mathrm{O}_{3}$ and $\mathrm{NO}$ climatologies generated from measurements obtained during commercial aircraft flights associated with the MOZAIC and NOXAR programs are incorporated with the data composites at $10-11 \mathrm{~km}$. As an example of the utility of these data composites, observations are compared to results from two global chemical transport models, MOZART and IMAGES, to help identify incorrect emission sources, incorrect strength of convection, and missing chemistry in the models. These comparisons suggest that in MOZART the $\mathrm{NO}_{x}$ biomass burning emissions may be too low and convection too weak and that the transport of ozone from the stratosphere in IMAGES is too great. The ozone profiles from the data composites are compared with ozonesonde climatologies and show that in some cases the aircraft data agree with the long-term averages, but in others, such as in the western Pacific during PEM-Tropics-A, agreement is lacking. Finally, the data composites provide temporal and spatial information, which can help identify the locations and seasons where new measurements would be most valuable. All of the data composites presented here are available via the Internet (http://aoss.engin.umich.edu/SASSarchive/).
\end{abstract}

\footnotetext{
${ }^{1}$ Atmospheric Chemistry Division, National Center for Atmospheric Research, Boulder Colorado.

2Service d'Aéronomie du CNRS, Paris, France.

${ }^{3}$ Belgian Institute for Space Aeronomy, Brussels, Belgium.

${ }^{4}$ Department of Atmospheric, Oceanic and Space Sciences and Department of Chemistry, University of Michigan, Ann Arbor.

${ }^{5}$ Max Planck Institute for Meteorology, Hamburg, Germany.

${ }^{6}$ Institute for Atmospheric Science, Eidgenossische Technische Hochschule, Zurich, Switzerland.

${ }^{7}$ Laboratoire d'Aérologie du CNRS, Toulouse, France.
}

Copyright 2000 by the American Geophysical Union.

Paper number 2000JD900232.

0148-0227/00/2000JD900232\$09.00

\section{Introduction}

Ozone in the troposphere affects atmospheric chemistry and climate in a number of important ways, including determining the oxidizing capacity of the atmosphere and radiative forcing. Ozone is transported from the stratosphere into the troposphere (at an uncertain rate) [e.g., Crutzen et al., 1999]. with the remainder of tropospheric ozone produced in situ. The concentrations of a number of chemical species, including $\mathrm{NO}_{x}$ $\left(=\mathrm{NO}+\mathrm{NO}_{2}\right)$, volatile organic compounds (VOCs). and $\mathrm{CO}$, determine the rate of ozone production and destruction, varying with region, altitude, and season.

In order to better understand the budget of tropospheric ozone, it is valuable to examine the observed 
seasonal and geographical variations in ozone and its precursors. Data composites constructed from airborne measurements can be used to assess our current knowledge of species distributions and to identify where additional observations are needed, to evaluate global chemical transport models (CTM), and to generate a priori profiles for satellite retrievals and for comparison with those measurements.

The present work is an extension of the $\mathrm{NO}, \mathrm{NO}_{x}$, and $\mathrm{NO}_{y}$ (total reactive nitrogen) "climatologies" of surface and airborne measurements presented by Emmons et al. [1997] and includes additional species with higher horizontal and vertical resolution. It also builds on compilations made previously for selected species primarily from the NASA Global Tropospheric Experiment (GTE) aircraft campaigns. These include a summary of $\mathrm{NO}_{x}$ measurements [Bradshaw et al., 2000], reactive nitrogen species and ozone [Thakur et al., 1999], and peroxides [O'Sullivan et al., 1999]. As a result of this work, we are able to provide in one archive a broader selection of species, from a greater number of campaigns, than have been previously available. While we have tried to compile an extensive data set, it is not yet comprehensive, and will be expanded as additional data becomes available.

In many cases it can be valuable to separate stratospheric and tropospheric air, so as to study these very different regimes independently [e.g., Logan, 1999]. However, for this study we have not filtered the data this way, choosing instead to look at the atmosphere as a whole, although concentrating on the troposphere. One of the parameters to evaluate in global models is the height of the tropopause, and not separating stratospheric and tropospheric air in these composites allows us to identify the tropopause. In addition, it is difficult to use a uniform criteria for distinguishing the two regions in these data sets, as there are different coincident measurements in the various campaigns.

The data that have been included in this collection have been released to the community on public archives and/or have been published in peer-reviewed journals. For the present work we have concentrated on data sets that have relatively large geographical coverage and include simultaneous measurements of a number of species, which are primarily made from aircraft. Additional measurements, including surface measurements, are available from the data archive. These observations and the associated measurement techniques and measurement campaigns are discussed in the next section. Following, the data composites are presented in two forms, as global maps and in vertical profiles for selected regions. The composites are then compared to climatologies from ozonesondes and two commercial aircraft programs, NOXAR and MOZAIC, to assess the representativeness of the composites. Finally, the results from two global CTMs, MOZART and IMAGES, are compared to the data composites as examples of their use for model evaluation.

\section{Observations}

The observations that are included in the data composites are discussed in this section. Following a brief discussion of the chemical species that are included, each of the measurement campaigns is briefly described. The techniques used for these measurements are discussed, and the data files used and created for the data composites are identified. These summaries are provided to assist the reader in interpreting the data composites presented in the following sections.

\subsection{Chemical Species}

The species from each measurement campaign that are included in the data composites presented here are listed in Table 1. Although many of the campaigns also included ground-, tower- or ship-based measurements, only aircraft measurements are discussed in this paper, with the exception of two sets of ozonesondes launched from ships.

A number of species related to ozone photochemistry are considered, including ozone $\left(\mathrm{O}_{3}\right)$, carbon monoxide $(\mathrm{CO})$, nonmethane hydrocarbons (NMHCs): ethane $\left(\mathrm{C}_{2} \mathrm{H}_{6}\right)$ and propane $\left(\mathrm{C}_{3} \mathrm{H}_{8}\right)$; reactive nitrogen species: nitric oxide (NO), $\mathrm{NO}_{x}\left(=\mathrm{NO}+\mathrm{NO}_{2}\right.$, nitrogen dioxide), peroxyacetyl nitrate ( $\left.\mathrm{PAN}, \mathrm{CH}_{3} \mathrm{CO}_{3} \mathrm{NO}_{2}\right)$, and nitric acid $\left(\mathrm{HNO}_{3}\right)$; and several $\mathrm{HO}_{x}$-related species: hydrogen peroxide $\left(\mathrm{H}_{2} \mathrm{O}_{2}\right)$, methyl hydroperoxide $\left(\mathrm{CH}_{3} \mathrm{OOH}\right)$, formaldehyde ( $\left.\mathrm{HCHO}\right)$, and acetone $\left(\mathrm{CH}_{3} \mathrm{COCH}_{3}\right)$. These species were either measured in situ, using direct (real-time) sampling techniques, or whole air sampling with subsequent laboratory analysis. Differential absorption lidar (DIAL) measurements of ozone were made on a number of these campaigns, providing high-resolution profiles of ozone concentration above and below the aircraft, and these results have also been included in this study. In addition, some ratios of chemical species have been calculated, including $\mathrm{PAN} / \mathrm{NO}_{x}, \mathrm{HNO}_{3} / \mathrm{NO}_{x}, \mathrm{H}_{2} \mathrm{O}_{2} / \mathrm{CH}_{3} \mathrm{OOH}$, and $\mathrm{C}_{3} \mathrm{H}_{8} / \mathrm{C}_{2} \mathrm{H}_{6}$.

NMHCs, $\mathrm{CO}$, and $\mathrm{NO}_{x}$ are source gases that can lead to $\mathrm{O}_{3}$ production. PAN and $\mathrm{HNO}_{3}$ are products of $\mathrm{NO}_{x}$ photochemistry with relatively long lifetimes (several weeks to a month in the upper troposphere) [Singh et al., 1990a]. Thus the ratios of PAN $/ \mathrm{NO}_{x}$ and $\mathrm{HNO}_{3} / \mathrm{NO}_{x}$ can be indicators of the photochemical processing that has occurred in an airmass [e.g., Ridley et al., 1990]. However, these relationships can be complicated by loss processes, such as the thermal decomposition of PAN, which may recycle $\mathrm{NO}_{x}$ and in this way provide a source of $\mathrm{NO}_{x}$ far away from primary emissions. As well, wet or dry deposition of $\mathrm{HNO}_{3}$ provides a sink for atmospheric $\mathrm{NO}_{x}$.

$\mathrm{H}_{2} \mathrm{O}_{2}$ and $\mathrm{CH}_{3} \mathrm{OOH}$ are products of methane and $\mathrm{CO}$ oxidation chemistry and are sinks for $\mathrm{HO}_{x}$ radicals. $\mathrm{As}_{2} \mathrm{O}_{2}$ is more soluble than $\mathrm{CH}_{3} \mathrm{OOH}$, the ratio $\mathrm{H}_{2} \mathrm{O}_{2} / \mathrm{CH}_{3} \mathrm{OOH}$ can provide an indication of convective activity [O'Sullivan et al., 1999]. Acetone has various 
Table 1. Campaigns and Chemical Species Included in Data Composites

\begin{tabular}{|c|c|c|c|}
\hline Campaign $^{a}$ & Dates & Platform & Species $^{b}$ \\
\hline CITE-1-Hawaii & Oct. 19 to Nov. 26,1983 & CV-990 & $\mathrm{O}_{3}, \mathrm{CO}, \mathrm{NO}$ \\
\hline CITE-1-Ames & April 20 to May 10,1984 & CV-990 & $\mathrm{O}_{3}, \mathrm{CO}, \mathrm{NO}$ \\
\hline STRATOZ-3 & June $4-26,1984$ & Caravelle 116 & $\mathrm{O}_{3}, \mathrm{CO}, \mathrm{NO}$ \\
\hline STRATOZ-3S & March $11-23,1985$ & Caravelle 116 & $\mathrm{O}_{3}, \mathrm{CO}$ \\
\hline ABLE-2A & July 12 to Aug. 13,1985 & Electra & $\mathrm{O}_{3}, \mathrm{CO}, \mathrm{NO}$ \\
\hline CITE-2 & Aug. 11 to Sept. 5, 1986 & Electra & $\mathrm{O}_{3}, \mathrm{CO}, \mathrm{NO}, \mathrm{NO}_{x}, \mathrm{PAN}, \mathrm{C}_{2} \mathrm{H}_{6}, \mathrm{C}_{3} \mathrm{H}_{8}$ \\
\hline ABLE-2B & April 1 to May 13,1987 & Electra & $\mathrm{O}_{3}, \mathrm{CO}, \mathrm{NO}, \mathrm{PAN}$ \\
\hline Shirase & Nov. 15 to Dec. $15,1987-1990$ & Ship/sondes & $\mathrm{O}_{3}$ \\
\hline TROPOZ-1 & Dec. $11-22,1987$ & Caravelle 116 & $\mathrm{O}_{3}, \mathrm{CO}, \mathrm{NO}$ \\
\hline ABLE-3A & July 7 to Aug. 17,1988 & Electra & $\mathrm{O}_{3}, \mathrm{DIAL}, \mathrm{CO}, \mathrm{NO}, \mathrm{NO}_{x}, \mathrm{PAN}, \mathrm{C}_{2} \mathrm{H}_{6}, \mathrm{C}_{3} \mathrm{H}_{8}$ \\
\hline AASE-1 & Jan. 2 to Feb. 15,1989 & DC-8 & $\mathrm{O}_{3}, \mathrm{NO}, \mathrm{NO}_{x}$ \\
\hline INSTAC-1 & March 5-10, 1989 & Merlin & $\mathrm{O}_{3}, \mathrm{NO}$ \\
\hline ELCHEM & July 27 to Aug. 22,1989 & Sabreliner & $\mathrm{O}_{3}, \mathrm{NO}, \mathrm{NO}_{x}$ \\
\hline CITE-3 & Aug. 22 to Sept. 29,1989 & Electra & $\mathrm{O}_{3}, \mathrm{CO}, \mathrm{NO}, \mathrm{NO}_{x}$ \\
\hline ABLE-3B & July 6 to Aug. 15,1990 & Electra & $\begin{array}{l}\mathrm{O}_{3}, \mathrm{DIAL}, \mathrm{CO}, \mathrm{NO}, \mathrm{NO}_{x}, \mathrm{PAN}, \mathrm{HNO}_{3}, \mathrm{C}_{2} \mathrm{H}_{6} \\
\mathrm{C}_{3} \mathrm{H}_{8}, \mathrm{CH}_{3} \mathrm{COCH}\end{array}$ \\
\hline TROPOZ-2 & Jan. 9 to Feb. 1, 1991 & Caravelle 116 & $\mathrm{O}_{3}, \mathrm{CO}, \mathrm{NO}, \mathrm{PAN}, \mathrm{C}_{2} \mathrm{H}_{6}, \mathrm{C}_{3} \mathrm{H}_{8}, \mathrm{H}_{2} \mathrm{O}_{2}, \mathrm{CH}_{2} \mathrm{O}$ \\
\hline PEM-West-A & Sept. 16 to Oct. 21,1991 & DC-8 & $\begin{array}{l}\mathrm{O}_{3}, \text { DIAL, CO, NO, NO }{ }^{*}, \mathrm{PAN}^{*} \mathrm{HNO}_{3}, \mathrm{C}_{2} \mathrm{H}_{6} \\
\mathrm{C}_{3} \mathrm{H}_{8}, \mathrm{H}_{2} \mathrm{O}_{2}, \mathrm{CH}_{3} \mathrm{OOH}, \mathrm{P}\left(\mathrm{O}_{3}\right)\end{array}$ \\
\hline AASE-2 & Jan. 14 to March 20, 1992 & DC-8 & $\mathrm{O}_{3}, \mathrm{CO}, \mathrm{NO}$ \\
\hline MLOPEX-2 & April 25 to May 11, 1992 & King Air & $\mathrm{O}_{3}, \mathrm{CO}, \mathrm{C}_{2} \mathrm{H}_{6}, \mathrm{C}_{3} \mathrm{H}_{8}, \mathrm{H}_{2} \mathrm{O}_{2}, \mathrm{CH}_{3} \mathrm{OOH}$ \\
\hline TRACE-A & Sept. 21 to Oct. 26,1992 & DC-8 & $\begin{array}{l}\mathrm{O}_{3}, \text { DIAL, CO, NO, NO }{ }_{x}^{*}, \mathrm{PAN}^{*} \mathrm{HNO}_{3}, \mathrm{C}_{2} \mathrm{H}_{6} \\
\mathrm{C}_{3} \mathrm{H}_{8}, \mathrm{CH}_{3} \mathrm{COCH}_{3}, \mathrm{CH}_{2} \mathrm{O}, \mathrm{H}_{2} \mathrm{O}_{2}, \mathrm{CH}_{3} \mathrm{OOH}, \mathrm{P}\left(\mathrm{O}_{3}\right)\end{array}$ \\
\hline OCTA-1 & March 23 to May 21, 1993 & $\mathrm{C}-130$ & $\mathrm{O}_{3}, \mathrm{CO}, \mathrm{NO}$ \\
\hline OCTA-2 & Aug. 19 to Sept. 1,1993 & C-130 & $\mathrm{O}_{3}, \mathrm{CO}, \mathrm{NO}$ \\
\hline OCTA-3 & Jan. $12-17,1994$ & $\mathrm{C}-130$ & $\mathrm{O}_{3}, \mathrm{CO}, \mathrm{NO}$ \\
\hline OCTA-4 & March 1 to April 26, 1994 & C-130 & $\mathrm{O}_{3}, \mathrm{CO}, \mathrm{NO}$ \\
\hline PEM-West-B & Feb. 7 to March 14,1994 & $\mathrm{DC}-8$ & $\begin{array}{l}\mathrm{O}_{3}, \mathrm{DIAL}, \mathrm{CO}, \mathrm{NO}, \mathrm{NO}_{x}{ }^{*}, \mathrm{PAN}, \mathrm{HNO}_{3}, \mathrm{C}_{2} \mathrm{H}_{6} \\
\mathrm{C}_{3} \mathrm{H}_{8}, \mathrm{CH}_{3} \mathrm{COCH}_{3}, \mathrm{H}_{2} \mathrm{O}_{2}, \mathrm{CH}_{3} \mathrm{OOH}, \mathrm{P}\left(\mathrm{O}_{3}\right)\end{array}$ \\
\hline $\mathrm{ACE}-1$ & Oct. 31 to Dec. 22,1995 & C-130 & $\mathrm{O}_{3}, \mathrm{CO}, \mathrm{NO}, \mathrm{C}_{2} \mathrm{H}_{6}, \mathrm{C}_{3} \mathrm{H}_{8}, \mathrm{H}_{2} \mathrm{O}_{2}, \mathrm{CH}_{3} \mathrm{OOH}$ \\
\hline TOTE & Dec. 6-22, 1995 & DC-8 & $\mathrm{O}_{3}, \mathrm{CO}, \mathrm{NO}$ \\
\hline VOTE & Jan. 20 to Feb. 19,1996 & DC-8 & $\mathrm{O}_{3}, \mathrm{CO}, \mathrm{NO}$ \\
\hline SUCCESS & April 15 to May 15,1996 & DC-8 & $\mathrm{O}_{3}, \mathrm{CO}, \mathrm{NO}$ \\
\hline PEM-Tropics-A & Aug. 15 to Oct. 5,1996 & P-3, DC-8 & $\begin{array}{l}\mathrm{O}_{3}, \text { DIAL, } \mathrm{CO}, \mathrm{NO}, \mathrm{NO}_{x}, \mathrm{PAN}, \mathrm{HNO}_{3}, \mathrm{C}_{2} \mathrm{H}_{6} \\
\mathrm{C}_{3} \mathrm{H}_{8}, \mathrm{H}_{2} \mathrm{O}_{2}, \mathrm{CH}_{3} \mathrm{OOH}, \mathrm{P}\left(\mathrm{O}_{3}\right)\end{array}$ \\
\hline
\end{tabular}

\footnotetext{
${ }^{a}$ Acronyms are defined in the text.

${ }^{b} \mathrm{NO}_{x}{ }^{*}$, from box model calculations; DIAL, differential absorption lidar measurements of $\mathrm{O}_{3}$ profiles; $\mathrm{P}\left(\mathrm{O}_{3}\right)$, ozone production and loss rates are available from box model calculations constrained by observations.
}

direct emission sources, and also is produced from the oxidation of hydrocarbons [Singh et al., 1995]. It is becoming apparent that acetone has a long lifetime $(\sim 100$ days) and is a significant source of $\mathrm{HO}_{x}$ in the upper troposphere [e.g., Singh et al., 1995; Wennberg et al., 1998; Müller and Brasseur, 1999]. HCHO, which is emitted by industrial sources, and is produced in the oxidation of methane and NMHCs, also contributes to the $\mathrm{HO}_{x}$ budget in the upper troposphere through photolysis.

As $\mathrm{C}_{3} \mathrm{H}_{8}$ has a lifetime of days, while that of $\mathrm{C}_{2} \mathrm{H}_{6}$ is weeks, their ratio $\left(\mathrm{C}_{3} \mathrm{H}_{8} / \mathrm{C}_{2} \mathrm{H}_{6}\right)$ can be used to estimate the length of time that an air mass has traveled from a source region [e.g., Gregory et al., 1996]. The analysis of Gregory et al. [1996] showed that, in general, when the ratio is greater than 0.3 the photochemical age of the air is less than approximately a day, whereas when the ratio is less than 0.1 it is well aged and more than 5 days from a source region. However, it is important to note that there are several factors which can affect this categorization. For example, in different regions the emission ratio of propane to ethane can differ, their lifetimes vary in different parts of the atmosphere, and the ratio can be affected by mixing and photochemistry [Gregory et al., 1996].

Ozone production and loss rates have been calculated for several of the aircraft campaigns, using photochemical box (0-D) models constrained by observations [e.g., Crawford et al., 1997; Schultz et al., 1999]. The results calculated by J. Crawford and D. Davis (GIT/NASA Langley) for the PEM-West, TRACE-A, and PEMTropics-A campaigns, and by M. Schultz and D. Jacob (Harvard) for PEM-Tropics-A have been made available to the community (GTE ftp site), and are included in these data composites. The 24-hour average (not instantaneous) production and loss rates have been used here. These calculations provide an overall view of the 
Table 2. Measurement Techniques and Uncertainties for Data Included in the Composites

\begin{tabular}{|c|c|c|c|c|c|c|}
\hline Campaign $^{a}$ & Species & Method $^{\mathrm{b}}$ & Uncertainty $^{c}$ & Investigator $^{\mathrm{d}}$ & Reference & Merge $^{e}$ \\
\hline CITE-1-Hawaii & $\begin{array}{l}\mathrm{O}_{3} \\
\mathrm{CO} \\
\mathrm{NO} \\
\mathrm{NO} \\
\mathrm{NO}\end{array}$ & $\begin{array}{l}\mathrm{C}_{2} \mathrm{H}_{4}-\mathrm{CL} \\
\mathrm{DACOM} \\
\mathrm{O}_{3}-\mathrm{CL} \\
\mathrm{O}_{3}-\mathrm{CL} \\
\mathrm{TP} / \mathrm{LIF}\end{array}$ & $\begin{array}{c}5 \% / 5 \mathrm{ppb} \\
3 \% \\
20 \%+13 \mathrm{ppt} \\
15 \%+9 \mathrm{ppt} \\
9 \%+12 \mathrm{ppt}\end{array}$ & $\begin{array}{l}\text { Gregory/LaRC } \\
\text { Sachse/LaRC } \\
\text { NOCAR } \\
\text { Torres/WFF } \\
\text { Davis/GIT }\end{array}$ & $\begin{array}{l}\text { Ridley et al. }[1987] \\
\text { Hoell et al. }[1987 \mathrm{~b}] \\
\text { Hoell et al. }[1987 \mathrm{a}] \\
\text { Hoell et al. }[1987 \mathrm{a}] \\
\text { Hoell et al. }[1987 \mathrm{a}]\end{array}$ & $\begin{array}{l}\text { G-at } \\
\text { G-at } \\
\text { G-at } \\
\text { G-at } \\
\text { G-at }\end{array}$ \\
\hline CITE-1-Ames & $\begin{array}{l}\mathrm{O}_{3} \\
\mathrm{CO} \\
\mathrm{NO} \\
\mathrm{NO}\end{array}$ & $\begin{array}{l}\mathrm{C}_{2} \mathrm{H}_{4}-\mathrm{CL} \\
\mathrm{DACOM} \\
\mathrm{O}_{3}-\mathrm{CL} \\
\mathrm{O}_{3}-\mathrm{CL}\end{array}$ & $\begin{array}{c}5 \% / 5 \mathrm{ppb} \\
3 \% \\
20 \%+13 \mathrm{ppt} \\
15 \%+9 \mathrm{ppt}\end{array}$ & $\begin{array}{l}\text { Gregory/LaRC } \\
\text { Sachse/LaRC } \\
\text { NOCAR } \\
\text { Torres/WFF }\end{array}$ & $\begin{array}{l}\text { Ridley et al. }[1987] \\
\text { Hoell et al. }[1987 \mathrm{~b}] \\
\text { Hoell et al. }[1987 \mathrm{a}] \\
\text { Hoell et al. }[1987 \mathrm{a}]\end{array}$ & $\begin{array}{l}\text { G-ncr } \\
\text { G-ncr } \\
\text { G-ncr } \\
\text { G-ncr }\end{array}$ \\
\hline STRATOZ-3 & $\begin{array}{l}\mathrm{O}_{3} \\
\mathrm{CO} \\
\mathrm{NO}\end{array}$ & $\begin{array}{l}\text { SAE } 1003 \\
\text { GC/FID } \\
\mathrm{O}_{3}-\mathrm{CL}\end{array}$ & $\begin{array}{c}2 \%+2 \mathrm{ppb} \\
4 \mathrm{ppb} \\
15 \%\end{array}$ & $\begin{array}{l}\text { Marenco/LA } \\
\text { Marenco/LA } \\
\text { Ehhalt/KFA }\end{array}$ & $\begin{array}{l}\text { Marenco and Said [1989] } \\
\text { Marenco et al. }[1989] \\
\text { Drummond et al. }[1988]\end{array}$ & \\
\hline STRATOZ-3S & $\begin{array}{l}\mathrm{O}_{3} \\
\mathrm{CO}\end{array}$ & $\begin{array}{l}\text { SAE } 1003 \\
\text { GC/FID }\end{array}$ & $\begin{array}{c}2 \%+2 \mathrm{ppb} \\
4 \mathrm{ppb}\end{array}$ & $\begin{array}{l}\text { Marenco/LA } \\
\text { Marenco/LA }\end{array}$ & $\begin{array}{l}\text { Marenco et al. }[1990] \\
\text { Marenco et al. }\end{array}$ & \\
\hline ABLE-2A & $\begin{array}{l}\mathrm{O}_{3} \\
\mathrm{CO} \\
\mathrm{NO}\end{array}$ & $\begin{array}{l}\mathrm{C}_{2} \mathrm{H}_{4}-\mathrm{CL} \\
\mathrm{DACOM} \\
\mathrm{O}_{3}-\mathrm{CL}\end{array}$ & $\begin{array}{c}5 \% / 5 \mathrm{ppb} \\
4.5 \% \\
15 \%+5 \mathrm{ppt}\end{array}$ & $\begin{array}{l}\text { Gregory/LaRC } \\
\text { Sachse/LaRC } \\
\text { Torres/WFF }\end{array}$ & $\begin{array}{l}\text { Gregory et al. }[1988] \\
\text { Sachse et al. }[1988] \\
\text { Torres and Buchan [1988] }\end{array}$ & $\begin{array}{l}\mathrm{L}-1 \mathrm{~min} \\
\mathrm{~L}-1 \mathrm{~min} \\
\mathrm{~L}-1 \mathrm{~min}\end{array}$ \\
\hline CITE-2 & $\begin{array}{l}\mathrm{O}_{3} \\
\mathrm{CO} \\
\mathrm{NO} \\
\mathrm{NO} \\
\mathrm{NO} \\
\mathrm{NO}_{2} \\
\mathrm{PAN} \\
\mathrm{PAN} \\
\mathrm{C}_{2} \mathrm{H}_{6}\end{array}$ & $\begin{array}{l}\mathrm{C}_{2} \mathrm{H}_{4}-\mathrm{CL} \\
\mathrm{Grab} / \mathrm{GC} \\
\mathrm{O}_{3}-\mathrm{CL} \\
\mathrm{O}_{3}-\mathrm{CL} \\
\mathrm{TP} / \mathrm{LIF} \\
\mathrm{Xe} \operatorname{lamp} \\
\mathrm{GC} / \mathrm{ECD} \\
\mathrm{GC} / \mathrm{ECD} \\
\mathrm{Grab} / \mathrm{GC}\end{array}$ & $\begin{array}{c}5 \% \\
10 \%+3 \mathrm{ppt} \\
15 \%+9 \mathrm{ppt} \\
18 \%+5 \mathrm{ppt} \\
30 \% \\
20-25 \% \\
30 \%\end{array}$ & $\begin{array}{l}\text { Gregory/LaRC } \\
\text { Condon/Ames } \\
\text { NOCAR } \\
\text { Torres/WFF } \\
\text { Bradshaw/GIT } \\
\text { NOCAR } \\
\text { Ridley/NCAR } \\
\text { Singh/Ames } \\
\text { Singh/Ames }\end{array}$ & $\begin{array}{l}\text { Gregory et al. }[1990 \mathrm{a}] \\
\text { Gregory et al. }[1990 \mathrm{a}] \\
\text { Gregory et al. }[1990 \mathrm{a}] \\
\text { Gregory et al. }[1990 \mathrm{~b}] \\
\text { Gregory et al. }[1990 \mathrm{c}] \\
\text { Gregory et al. }[1990 \mathrm{c}] \\
\text { Singh et al. }[1990 \mathrm{a}]\end{array}$ & $\begin{array}{l}\text { L-1min } \\
\text { L-1min } \\
\text { L-1min } \\
\text { L-1min } \\
\text { L-1min } \\
\text { L-1min } \\
\text { L-1 min } \\
\text { L-1 min } \\
\text { L-1min }\end{array}$ \\
\hline ABLE-2B & $\begin{array}{l}\mathrm{O}_{3} \\
\mathrm{CO} \\
\mathrm{NO} \\
\mathrm{PAN}\end{array}$ & $\begin{array}{l}\mathrm{C}_{2} \mathrm{H}_{4}-\mathrm{CL} \\
\mathrm{DACOM} \\
\mathrm{O}_{3}-\mathrm{CL} \\
\mathrm{GC} / \mathrm{ECD}\end{array}$ & $\begin{array}{c}5 \% / 5 \mathrm{ppb} \\
6 \% \\
15 \%+5 \mathrm{ppt} \\
35 \%\end{array}$ & $\begin{array}{l}\text { Gregory/LaRC } \\
\text { Sachse/LaRC } \\
\text { Torres/WFF } \\
\text { Singh/Ames }\end{array}$ & $\begin{array}{l}\text { Gregory et al. }[1990 \mathrm{e}] \\
\text { Harriss et al. }[1990 \mathrm{~b}] \\
\text { Torres and Buchan }[1988] \\
\text { Singh et al. }[1990 \mathrm{~b}]\end{array}$ & $\begin{array}{l}\text { G-1min } \\
\text { G-1min } \\
\text { G-1min } \\
\text { G-1min }\end{array}$ \\
\hline Shirase & $\mathrm{O}_{3}$ & ECC sondes & & Takao/JMA & Matsubara et al. [1991] & \\
\hline TROPOZ-1 & $\begin{array}{l}\mathrm{O}_{3} \\
\mathrm{CO} \\
\mathrm{NO}\end{array}$ & $\begin{array}{l}\text { SAE } 1003 \\
\text { GC/FID } \\
\mathrm{O}_{3}-\mathrm{CL}\end{array}$ & $\begin{array}{c}2 \%+2 \mathrm{ppb} \\
4 \mathrm{ppb} \\
10 \mathrm{ppt}\end{array}$ & $\begin{array}{l}\text { Marenco/LA } \\
\text { Marenco/LA } \\
\text { Rohrer/KFA }\end{array}$ & $\begin{array}{l}\text { Marenco et al. }[1990] \\
\text { Marenco et al. }[1990] \\
\text { Jonqu乞ères et al. }[1998]\end{array}$ & \\
\hline ABLE-3A & $\begin{array}{l}\mathrm{O}_{3} \\
\mathrm{O}_{3} \text { prof. } \\
\mathrm{CO} \\
\mathrm{NO} \\
\mathrm{NO}_{2} \\
\mathrm{PAN} \\
\mathrm{C}_{2} \mathrm{H}_{6}\end{array}$ & $\begin{array}{l}\mathrm{C}_{2} \mathrm{H}_{4}-\mathrm{CL} \\
\text { DIAL } \\
\text { DACOM } \\
\text { TP/LIF } \\
\text { XeF laser } \\
\text { GC/ECD } \\
\text { Grab/GC }\end{array}$ & $\begin{array}{c}5 \% / 5 \mathrm{ppb} \\
10 \% / 3 \mathrm{ppb} \\
3 \% \\
16 \% \\
18 \% \\
35 \% \\
8 \%\end{array}$ & $\begin{array}{l}\text { Gregory/LaRC } \\
\text { Browell/LaRC } \\
\text { Sachse/LaRC } \\
\text { Bradshaw/GIT } \\
\text { Bradshaw/GIT } \\
\text { Singh/Ames } \\
\text { Rowland/UCI }\end{array}$ & $\begin{array}{l}\text { Gregory et al. }[1992] \\
\text { Browell et al. }[1992] \\
\text { Harriss et al. }[1992 \mathrm{~b}] \\
\text { Sandholm et al. }[1992] \\
\text { Sandholm et al. }[1992] \\
\text { Singh et al. }[1992] \\
\text { Blake et al. }[1992]\end{array}$ & $\begin{array}{l}\text { L-1min } \\
\text { L-1min } \\
\text { L-1min } \\
\text { L-1min } \\
\text { L-1min } \\
\text { L-1min } \\
\text { L-1min }\end{array}$ \\
\hline AASE-1 & $\begin{array}{l}\mathrm{O}_{3} \\
\mathrm{NO} \\
\mathrm{NO}_{2}\end{array}$ & $\begin{array}{l}\mathrm{C}_{2} \mathrm{H}_{4}-\mathrm{CL} \\
\mathrm{O}_{3}-\mathrm{CL} \\
\text { Xe lamp }\end{array}$ & $\begin{array}{c}5 \% \\
20 \%\end{array}$ & $\begin{array}{l}\text { Gregory/LaRC } \\
\text { Carroll/NOAA } \\
\text { Carroll/NOAA }\end{array}$ & & $\begin{array}{l}\mathrm{L}-1 \mathrm{~min} \\
\mathrm{~L}-1 \mathrm{~min} \\
\mathrm{~L}-1 \mathrm{~min}\end{array}$ \\
\hline
\end{tabular}

budget of ozone in several regions of the troposphere, and provide an additional comparison in the evaluation of global models. Box model calculations of $\mathrm{NO}_{x}$ from Crawford and Davis for PEM-West-A, -B, and TRACE$A$ have also been used here, instead of the measured $\mathrm{NO}_{x}$.

\subsection{Campaign Descriptions}

Brief summaries of the campaigns are provided below to assist the reader in interpreting the data composites. The particular focus and characteristics of the campaign, with references to journal special sections and 
Table 2. (continued)

\begin{tabular}{|c|c|c|c|c|c|c|}
\hline Campaign $^{a}$ & Species & Method $^{\mathbf{b}}$ & Uncertainty $^{\mathrm{c}}$ & Investigator $^{d}$ & Reference & Merge $^{e}$ \\
\hline INSTAC-1 & $\begin{array}{l}\mathrm{O}_{3} \\
\mathrm{NO}\end{array}$ & $\begin{array}{l}\mathrm{ECC} \\
\mathrm{O}_{3}-\mathrm{CL}\end{array}$ & $\begin{array}{c}10 \% / 2 \mathrm{ppb} \\
5 \mathrm{ppt}\end{array}$ & $\begin{array}{l}\text { Kondo/Nagoya } \\
\text { Kondo/Nagoya }\end{array}$ & $\begin{array}{l}\text { Kondo et al. }[1993] \\
\text { Kondo et al. }[1993]\end{array}$ & $\begin{array}{l}\mathrm{L}-1 \mathrm{~min} \\
\mathrm{~L}-1 \mathrm{~min}\end{array}$ \\
\hline ELCHEM & $\begin{array}{l}\mathrm{NO} \\
\mathrm{NO}_{2} \\
\mathrm{O}_{3}\end{array}$ & $\begin{array}{l}\mathrm{O}_{3}-\mathrm{CL} \\
\mathrm{Xe} \text { lamp } \\
\mathrm{NO}-\mathrm{CL}\end{array}$ & $\begin{array}{c}15-27 \% \\
16-27 \% \\
4 \%+2 \mathrm{ppb}\end{array}$ & $\begin{array}{l}\text { Ridley/NCAR } \\
\text { Ridley/NCAR } \\
\text { Ridley/NCAR }\end{array}$ & $\begin{array}{l}\text { Ridley et al. [1994] } \\
\text { Rudley et al. [1994] } \\
\text { Rudley et al. }[1994]\end{array}$ & $\begin{array}{l}\mathrm{L}-1 \mathrm{~min} \\
\mathrm{~L}-1 \mathrm{~min} \\
\mathrm{~L}-1 \mathrm{~min}\end{array}$ \\
\hline CITE-3 & $\begin{array}{l}\mathrm{O}_{3} \\
\mathrm{CO} \\
\mathrm{NO} \\
\mathrm{NO}_{2}\end{array}$ & $\begin{array}{l}\mathrm{C}_{2} \mathrm{H}_{4}-\mathrm{CL} \\
\mathrm{DACOM} \\
\mathrm{TP} / \mathrm{LIF} \\
\text { Xe lamp }\end{array}$ & $\begin{array}{c}5 \% / 5 \mathrm{ppb} \\
3 \% \\
41 \% \\
53 \%\end{array}$ & $\begin{array}{l}\text { Gregory/LaRC } \\
\text { Sachse/LaRC } \\
\text { Bradshaw/GIT } \\
\text { Bradshaw/GIT }\end{array}$ & $\begin{array}{l}\text { Anderson et al. }[1993 \mathrm{a}] \\
\text { Anderson et al. }[1993 \mathrm{a}] \\
\text { Davis et al. }[1993] \\
\text { Davis et al. }[1993]\end{array}$ & $\begin{array}{l}\text { G-3min } \\
\text { G-3min } \\
\text { G-3min } \\
\text { G-3min }\end{array}$ \\
\hline ABLE-3B & $\begin{array}{l}\mathrm{O}_{3} \\
\mathrm{O}_{3} \text { prof. } \\
\mathrm{CO} \\
\mathrm{NO} \\
\mathrm{NO}_{2} \\
\mathrm{PAN} \\
\mathrm{HNO}_{3} \\
\mathrm{C}_{2} \mathrm{H}_{6} \\
\mathrm{CH}_{3} \mathrm{COCH}_{3}\end{array}$ & $\begin{array}{l}\mathrm{C}_{2} \mathrm{H}_{4}-\mathrm{CL} \\
\text { DIAL } \\
\text { DACOM } \\
\text { TP/LIF } \\
\text { Xe lamp } \\
\text { GC/ECD } \\
\text { Mist/IC } \\
\text { Grab/GC } \\
\text { GC/RGD }\end{array}$ & $\begin{array}{c}5 \% / 5 \mathrm{ppb} \\
10 \% / 3 \mathrm{ppb} \\
3 \% \\
41 \% \\
53 \% \\
35 \% \\
20-30 \% \\
7 \% \\
25 \%\end{array}$ & $\begin{array}{l}\text { Gregory/LaRC } \\
\text { Browell/LaRC } \\
\text { Sachse/LaRC } \\
\text { Bradshaw/GIT } \\
\text { Bradshaw/GIT } \\
\text { Singh/Ames } \\
\text { Talbot/UNH } \\
\text { Rowland/UCI } \\
\text { Singh/Ames }\end{array}$ & $\begin{array}{l}\text { Anderson et al. }[1994] \\
\text { Browell et al. }[1994] \\
\text { Harrıss et al. }[1994] \\
\text { Sandholm et al. }[1994] \\
\text { Sandholm et al. }[1994] \\
\text { Singh et al. }[1994 \mathrm{a}] \\
\text { Talbot et al. }[1994] \\
\text { Blake et al. }[1994] \\
\text { Singh et al. }[1994 \mathrm{~b}]\end{array}$ & $\begin{array}{l}\text { L-1min } \\
\text { L-1min } \\
\text { L-1min } \\
\text { L-1min } \\
\text { L-1min } \\
\text { L-1min } \\
\text { L-1min } \\
\text { L-1min } \\
\text { L-1min }\end{array}$ \\
\hline TROPOZ-2 & $\begin{array}{l}\mathrm{O}_{3} \\
\mathrm{CO} \\
\mathrm{NO} \\
\mathrm{PAN} \\
\mathrm{C}_{2} \mathrm{H}_{6} \\
\mathrm{H}_{2} \mathrm{O}_{2} \\
\mathrm{CH}_{2} \mathrm{O}\end{array}$ & $\begin{array}{l}\text { TEI 49-103 } \\
\text { GC/Hg det } \\
\mathrm{O}_{3}-\mathrm{CL} \\
\text { GC/ECD } \\
\text { grab/GC } \\
\text { Enz. Fluor. } \\
\text { grab/HPLC }\end{array}$ & $\begin{array}{c}2 \%+2 \mathrm{ppb} \\
2 \mathrm{ppb} \\
15 \%+25 \mathrm{ppt} \\
35 \% \\
5-10 \% \\
10 \% \\
15-40 \%\end{array}$ & $\begin{array}{l}\text { Marenco/LA } \\
\text { Marenco/LA } \\
\text { Ehhalt/KFA } \\
\text { Perros/U. Paris } \\
\text { Boissard/CNRS } \\
\text { Perros/U. Paris } \\
\text { Arlander/KFA }\end{array}$ & $\begin{array}{l}\text { Marenco et al. }[1995] \\
\text { Gouget et al. }[1996] \\
\text { Rohrer et al. }[1997] \\
\text { Perros [1994] } \\
\text { Boissard et al. [1996] } \\
\text { Perros [1993] } \\
\text { Arlander et al. }[1995]\end{array}$ & \\
\hline PEM-West-A & $\begin{array}{l}\mathrm{O}_{3} \\
\mathrm{O}_{3} \text { prof. } \\
\mathrm{CO} \\
\mathrm{NO} \\
\mathrm{NO} \\
\mathrm{NO}_{x} \\
\mathrm{PAN} \\
\mathrm{HNO}_{3} \\
\mathrm{C}_{2} \mathrm{H}_{6} \\
\mathrm{H}_{2} \mathrm{O}_{2} \\
\mathrm{CH}_{3} \mathrm{OOH} \\
\mathrm{P}\left(\mathrm{O}_{3}\right)\end{array}$ & $\begin{array}{l}\mathrm{C}_{2} \mathrm{H}_{4}-\mathrm{CL} \\
\text { DIAL } \\
\text { DACOM } \\
\text { TP/LIF } \\
\mathrm{O}_{3}-\mathrm{CL} \\
\text { Box model } \\
\text { GC/ECD } \\
\text { Mist/IC } \\
\text { Grab/GC } \\
\text { Grab/HPLC } \\
\text { Grab/HPLC } \\
\text { Box model }\end{array}$ & $\begin{array}{c}8 \% / 3 \mathrm{ppb} \\
15 \% / 3 \mathrm{ppb} \\
2 \% / 1 \mathrm{ppb} \\
28 \% \\
6 \%+6 \mathrm{ppt} \\
\\
30 \% \\
37 \% \\
8 \% \\
10 \%+15 \mathrm{ppt} \\
15 \%+20 \mathrm{ppt}\end{array}$ & $\begin{array}{l}\text { Gregory/LaRC } \\
\text { Browell/LaRC } \\
\text { Sachse/LaRC } \\
\text { Bradshaw/GIT } \\
\text { Kondo/Nagoya } \\
\text { Crawford/LaRC } \\
\text { Singh/Ames } \\
\text { Talbot/UNH } \\
\text { Rowland/UCI } \\
\text { Heikes/URI } \\
\text { Heikes/URI } \\
\text { Crawford/LaRC }\end{array}$ & $\begin{array}{l}\text { Hoell et al. }[1996] \\
\text { Hoell et al. }[1996] \\
\text { Hoell et al. }[1996] \\
\text { Hoell et al. }[1996] \\
\text { Hoell et al. }[1996] \\
\text { Crawford et al. }[1996] \\
\text { Hoell et al. }[1996] \\
\text { Hoell et al. }[1996] \\
\text { Hoell et al. }[1996] \\
\text { Hoell et al. }[1996] \\
\text { Hoell et al. }[1996] \\
\text { Crawford et al. }[1996]\end{array}$ & $\begin{array}{l}\text { L-1min } \\
\text { L-1min } \\
\text { L-1min } \\
\text { L-1min } \\
\text { L-1min } \\
\\
\text { L-1min } \\
\text { L-1min } \\
\text { L-1min } \\
\text { L-1min } \\
\text { L-1min }\end{array}$ \\
\hline MLOPEX-2 & $\begin{array}{l}\mathrm{O}_{3} \\
\mathrm{CO} \\
\mathrm{C}_{2} \mathrm{H}_{6} \\
\mathrm{H}_{2} \mathrm{O}_{2} \\
\mathrm{CH}_{3} \mathrm{OOH}\end{array}$ & $\begin{array}{l}\text { NO-CL } \\
\text { TEI } 48 \\
\text { Grab/GC } \\
\text { Enz. Fluor. } \\
\text { Enz. Fluor. }\end{array}$ & $\begin{array}{c}5 \% \\
18 \mathrm{ppb} \\
5-10 \% \\
15 \% \\
15 \%\end{array}$ & $\begin{array}{l}\text { Ridley/NCAR } \\
\text { Kok/NCAR } \\
\text { Greenberg/NCAR } \\
\text { Kok/NCAR } \\
\text { Kok/NCAR }\end{array}$ & $\begin{array}{l}\text { Ridley et al. }[1997] \\
\text { Rudley et al. }[1997] \\
\text { Greenberg et al. }[1996] \\
\text { Staffelbach et al. }[1996] \\
\text { Staffelbach et al. }[1996]\end{array}$ & $\begin{array}{l}\text { L-1min } \\
\text { L-1min } \\
\text { L-1min } \\
\text { L-1min } \\
\text { L-1min }\end{array}$ \\
\hline AASE-2 & $\begin{array}{l}\mathrm{O}_{3} \\
\mathrm{CO} \\
\mathrm{NO}\end{array}$ & $\begin{array}{l}\text { NO-CL } \\
\text { DACOM } \\
\mathrm{O}_{3}-\mathrm{CL}\end{array}$ & $\begin{array}{l}5 \% \\
2 \%\end{array}$ & $\begin{array}{l}\text { Ridley/NCAR } \\
\text { Sachse/LaRC } \\
\text { Ridley/NCAR }\end{array}$ & $\begin{array}{l}\text { Wernhermer et al. }[1993] \\
\text { Anderson et al. }[1993 c]\end{array}$ & $\begin{array}{l}\mathrm{L}-1 \mathrm{~min} \\
\mathrm{~L}-1 \mathrm{~min} \\
\mathrm{~L}-1 \mathrm{~min}\end{array}$ \\
\hline
\end{tabular}

other publications of the data, are given. The dates and observing platforms used for the campaigns are listed chronologically in Table 1 , with the specifics of the observations given in Table 2 along with additional references. Results from the NASA Global Tropospheric Experiment (GTE) campaigns have been published in special issues of the Journal of Geophysical Research and are referenced in the discussion below. Most of the other observations have also been published, and the reader is directed to all of these references for further details regarding the measurements.

The GTE Chemical Instrumentation Test and Evaluations (CITE) were a series of intercomparisons of different measurement techniques. CITE-1 provided intercomparisons of $\mathrm{CO}, \mathrm{NO}$, and $\mathrm{OH}$ measurements during two aircraft campaigns (see Beck et al. [1987], and ac- 
Table 2. (continued)

\begin{tabular}{|c|c|c|c|c|c|c|}
\hline Campaign $^{a}$ & Species & Method $^{\mathrm{b}}$ & Uncertainty $^{c}$ & Investigator $^{\mathrm{d}}$ & Reference & Merge $e^{e}$ \\
\hline TRACE-A & $\begin{array}{l}\mathrm{O}_{3} \\
\mathrm{O}_{3} \text { prof. } \\
\mathrm{CO} \\
\mathrm{NO} \\
\mathrm{NO}_{x} \\
\mathrm{PAN} \\
\mathrm{HNO}_{3} \\
\mathrm{C}_{2} \mathrm{H}_{6} \\
\mathrm{H}_{2} \mathrm{O}_{2} \\
\mathrm{CH}_{3} \mathrm{OOH} \\
\mathrm{CH}_{3} \mathrm{COCH} \\
\mathrm{CH}_{2} \mathrm{O} \\
\mathrm{P}\left(\mathrm{O}_{3}\right)\end{array}$ & $\begin{array}{l}\mathrm{C}_{2} \mathrm{H}_{4}-\mathrm{CL} \\
\text { DIAL } \\
\text { DACOM } \\
\text { TP/LIF } \\
\text { Box model } \\
\text { GC/ECD } \\
\text { Mist/IC } \\
\text { Grab/GC } \\
\text { Grab/HPLC } \\
\text { Grab/HPLC } \\
\text { GC/RGD } \\
\text { Grab/HPLC } \\
\text { Box model }\end{array}$ & $\begin{array}{c}3 \% \\
10 \% / 2 \mathrm{ppb} \\
5 \% \\
15 \% \\
20 \% \\
15-20 \% \\
5 \% \\
2 \%+4 \mathrm{ppt} \\
7 \%+10 \mathrm{ppt} \\
5 \%+30 \mathrm{ppt}\end{array}$ & $\begin{array}{l}\text { Gregory/LaRC } \\
\text { Browell/LaRC } \\
\text { Sachse/LaRC } \\
\text { Bradshaw/GIT } \\
\text { Crawford/LaRC } \\
\text { Singh/Ames } \\
\text { Talbot/UNH } \\
\text { Blake/UCI } \\
\text { Heikes/URI } \\
\text { Heikes/URI } \\
\text { Singh/Ames } \\
\text { Heikes/URI } \\
\text { Crawford/LaRC }\end{array}$ & & $\begin{array}{l}\text { L-1min } \\
\text { L-1min } \\
\text { L-1min } \\
\text { L-1min } \\
\text { L-1min } \\
\text { L-1min } \\
\text { L-1min } \\
\text { L-1min } \\
\text { L-1min } \\
\text { L-1min } \\
\text { L-1min } \\
\text { L-1min }\end{array}$ \\
\hline OCTA & $\begin{array}{l}\mathrm{O}_{3} \\
\mathrm{CO} \\
\mathrm{NO}\end{array}$ & $\begin{array}{l}\text { Bendix } \\
\text { Res. Fluor. } \\
\mathrm{O}_{3}-\mathrm{CL}\end{array}$ & $\begin{array}{c}10 \% \\
10 \%+10 \text { ppt }\end{array}$ & $\begin{array}{l}\text { Gerbig/KFA } \\
\text { Gerbig/KFA }\end{array}$ & & $\begin{array}{l}\mathrm{L}-1 \mathrm{~min} \\
\mathrm{~L}-1 \mathrm{~min} \\
\mathrm{~L}-1 \mathrm{~min}\end{array}$ \\
\hline PEM-West-B & $\begin{array}{l}\mathrm{O}_{3} \\
\mathrm{O}_{3} \text { prof. } \\
\mathrm{CO} \\
\mathrm{NO} \\
\mathrm{NO} \\
\mathrm{NO}_{x} \\
\mathrm{PAN} \\
\mathrm{HNO}_{3} \\
\mathrm{C}_{2} \mathrm{H}_{6} \\
\mathrm{H}_{2} \mathrm{O}_{2} \\
\mathrm{CH}_{3} \mathrm{OOH} \\
\mathrm{CH}_{3} \mathrm{COCH} \\
\mathrm{P}_{3}\left(\mathrm{O}_{3}\right)\end{array}$ & $\begin{array}{l}\mathrm{C}_{2} \mathrm{H}_{4}-\mathrm{CL} \\
\text { DIAL } \\
\text { DACOM } \\
\text { TP/LIF } \\
\mathrm{O}_{3}-\mathrm{CL} \\
\text { Box model } \\
\text { GC/ECD } \\
\text { Mist/IC } \\
\text { Grab/GC } \\
\text { Grab/HPLC } \\
\text { Grab/HPLC } \\
\text { GC/RGD } \\
\text { Box model }\end{array}$ & $\begin{array}{c}5 \% / 3 \mathrm{ppb} \\
15 \% / 3 \mathrm{ppb} \\
2 \% \\
40 \% \\
12 \%+7 \mathrm{ppt} \\
30 \% \\
60 \% \\
6 \% \\
10 \%+15 \mathrm{ppt} \\
15 \%+20 \mathrm{ppt} \\
30 \%\end{array}$ & $\begin{array}{l}\text { Gregory/LaRC } \\
\text { Browell/LaRc } \\
\text { Sachse/LaRC } \\
\text { Bradshaw/GIT } \\
\text { Kondo/Nagoya } \\
\text { Crawford/LaRC } \\
\text { Singh/Ames } \\
\text { Talbot/UNH } \\
\text { Blake/UCI } \\
\text { Heikes/URI } \\
\text { Heikes/URI } \\
\text { Singh/Ames } \\
\text { Crawford/LaRC }\end{array}$ & $\begin{array}{l}\text { Hoell et al. [1997] } \\
\text { Hoell et al. [1997] } \\
\text { Hoell et al. [1997] } \\
\text { Hoell et al. [1997] } \\
\text { Hoell et al. [1997] } \\
\text { Crawford et al. [1997] } \\
\text { Hoell et al. }[1997] \\
\text { Hoell et al. [1997] } \\
\text { Hoell et al. [1997] } \\
\text { Hoell et al. [1997] } \\
\text { Hoell et al. [1997] } \\
\text { Hoell et al. [1997] } \\
\text { Crawford et al. }[1997]\end{array}$ & $\begin{array}{l}\text { L-1min } \\
\text { L-1min } \\
\text { L-1min } \\
\text { L-1min } \\
\text { L-1min } \\
\text { L-1min } \\
\text { L-1min } \\
\text { L-1min } \\
\text { L-1min } \\
\text { L-1min } \\
\text { L-1min } \\
\text { L-1min }\end{array}$ \\
\hline $\mathrm{ACE}-1$ & $\begin{array}{l}\mathrm{O}_{3} \\
\mathrm{CO} \\
\mathrm{NO} \\
\mathrm{C}_{2} \mathrm{H}_{6} \\
\mathrm{H}_{2} \mathrm{O}_{2} \\
\mathrm{CH}_{3} \mathrm{OOH} \\
\mathrm{O}_{3}\end{array}$ & $\begin{array}{l}\text { NO-CL } \\
\text { TEI } 48 \\
\mathrm{O}_{3}-\mathrm{CL} \\
\text { Grab/GC } \\
\text { Enz. Fluor. } \\
\text { Enz. Fluor. } \\
\text { ECC sondes }\end{array}$ & $15 \%$ & $\begin{array}{l}\text { Kok/NCAR } \\
\text { Kok/NCAR } \\
\text { Bradshaw/GIT } \\
\text { Blake/UCI } \\
\text { Kok/NCAR } \\
\text { Kok/NCAR } \\
\text { Johnson/PMEL }\end{array}$ & Kok et al. [1998] & $\begin{array}{l}\text { L-1min } \\
\text { L-1min } \\
\text { L-1min } \\
\text { L-1min } \\
\text { L-1min } \\
\text { L-1min }\end{array}$ \\
\hline TOTE/VOTE & $\begin{array}{l}\mathrm{O}_{3} \\
\mathrm{CO} \\
\mathrm{NO}\end{array}$ & $\begin{array}{l}\mathrm{NO}-\mathrm{CL} \\
\mathrm{DACOM} \\
\mathrm{O}_{3}-\mathrm{CL}\end{array}$ & $1 \%$ & $\begin{array}{l}\text { Ridley/NCAR } \\
\text { Sachse/LaRC } \\
\text { Ridley/NCAR }\end{array}$ & & $\begin{array}{l}\mathrm{L}-1 \min \\
\mathrm{L}-1 \min \\
\mathrm{L}-1 \min \end{array}$ \\
\hline SUCCESS & $\begin{array}{l}\mathrm{O}_{3} \\
\mathrm{CO} \\
\mathrm{NO}\end{array}$ & $\begin{array}{l}\mathrm{NO}-\mathrm{CL} \\
\mathrm{DACOM} \\
\mathrm{O}_{3}-\mathrm{CL}\end{array}$ & $\begin{array}{c}1 \% \\
4-6 \%\end{array}$ & $\begin{array}{l}\text { Ridley/NCAR } \\
\text { Sachse/LaRC } \\
\text { Ridley/NCAR }\end{array}$ & Campos et al. [1998] & $\begin{array}{l}\mathrm{L}-1 \min \\
\mathrm{L}-1 \min \\
\mathrm{L}-1 \min \end{array}$ \\
\hline PEM-Tropics-A DC8 & $\begin{array}{l}\mathrm{O}_{3} \\
\mathrm{O}_{3} \text { prof. } \\
\mathrm{CO}\end{array}$ & $\begin{array}{l}\mathrm{C}_{2} \mathrm{H}_{4}-\mathrm{CL} \\
\text { DIAL } \\
\text { DACOM }\end{array}$ & $\begin{array}{c}5 \% / 3 \mathrm{ppb} \\
15 \% / 3 \mathrm{ppb} \\
2 \%\end{array}$ & $\begin{array}{l}\text { Gregory/LaRC } \\
\text { Browell/LaRc } \\
\text { Sachse/LaRC }\end{array}$ & $\begin{array}{l}\text { Hoell et al. }[1999] \\
\text { Hoell et al. }[1999] \\
\text { Hoell et al. }[1999]\end{array}$ & $\begin{array}{l}\mathrm{H}-1 \mathrm{~min} \\
\mathrm{H}-1 \mathrm{~min}\end{array}$ \\
\hline
\end{tabular}

companying papers). The first set of flights were in November 1983 with five flights based in California and five in Hawaii. The second campaign was conducted in April-May 1984 from California. Measurements of NO were made by the NOAA/NCAR (NOCAR) and the NASA/Wallops (WFF) groups using chemiluminescence and by the Georgia Tech (GIT) group with a twophoton laser-induced fluorescence (TP/LIF) technique
[Hoell et al., 1987a]. Since these measurements agreed well, an average of these data have been used in the composites. $\mathrm{CO}$ was sampled using the Differential $\mathrm{Ab}-$ sorption CO Measurements (DACOM) instrument, as well as by grab samples analyzed by gas chromatography (GC) [Hoell et al., 1987b]. The DACOM instrument provided continuous measurements, agreed reasonably well with the grab samples, and has proven to 
Table 2. (continued)

\begin{tabular}{|c|c|c|c|c|c|c|}
\hline Campaign $^{a}$ & Species & Method $^{\mathrm{b}}$ & Uncertainty $^{c}$ & Investigator $^{d}$ & Reference & Merge $^{e}$ \\
\hline & $\begin{array}{l}\mathrm{NO} \\
\mathrm{NO}_{2} \\
\mathrm{PAN} \\
\mathrm{HNO}_{3} \\
\mathrm{C}_{2} \mathrm{H}_{6} \\
\mathrm{H}_{2} \mathrm{O}_{2} \\
\mathrm{CH}_{3} \mathrm{OOH} \\
\left.\mathrm{P}_{3} \mathrm{O}_{3}\right) \\
\mathrm{P}\left(\mathrm{O}_{3}\right)\end{array}$ & $\begin{array}{l}\text { TP/LIF } \\
\text { PF-TP/LIF } \\
\text { GC/ECD } \\
\text { Mist/IC } \\
\text { Grab/GC } \\
\text { Grab/HPLC } \\
\text { Grab/HPLC } \\
\text { Box model } \\
\text { Box model }\end{array}$ & $\begin{array}{c}69 \pm 68.5 \mathrm{ppt} \\
14.6 \pm 18.2 \mathrm{ppt} \\
10 \% \\
60-70 \% \\
6 \% \\
30 \%+10 \mathrm{ppt} \\
30 \%+15 \mathrm{ppt}\end{array}$ & $\begin{array}{l}\text { Bradshaw/GIT } \\
\text { Bradshaw/GIT } \\
\text { Singh/Ames } \\
\text { Talbot/UNH } \\
\text { Blake/UCI } \\
\text { Heikes/URI } \\
\text { Heikes/URI } \\
\text { Crawford/LaRC } \\
\text { Jacob/Harvard }\end{array}$ & $\begin{array}{l}\text { Hoell et al. }[1999] \\
\text { Hoell et al. [1999] } \\
\text { Hoell et al. }[1999] \\
\text { Hoell et al. [1999] } \\
\text { Hoell et al. [1999] } \\
\text { Hoell et al. [1999] } \\
\text { Hoell et al. [1999] }\end{array}$ & $\begin{array}{c}\text { H-1min } \\
\text { H-1min } \\
\text { H-PAN } \\
\text { H-HNO } \\
\text { H-HC } \\
\text { H-PER } \\
\text { H-PER } \\
\\
\text { H-1min }\end{array}$ \\
\hline PEM-Tropics-A P3 & $\begin{array}{l}\mathrm{O}_{3} \\
\mathrm{CO} \\
\mathrm{NO} \\
\mathrm{C}_{2} \mathrm{H}_{6} \\
\mathrm{H}_{2} \mathrm{O}_{2} \\
\mathrm{CH}_{3} \mathrm{OOH}\end{array}$ & $\begin{array}{l}\text { NO-CL } \\
\text { DACOM } \\
\mathrm{O}_{3}-\mathrm{CL} \\
\text { Grab/GC } \\
\text { Grab/HPLC } \\
\text { Grab/HPLC }\end{array}$ & $\begin{array}{c}15 \% \\
3 \% \\
27 \% \\
6 \% \\
30 \%+10 \mathrm{ppt} \\
30 \%+15 \mathrm{ppt}\end{array}$ & $\begin{array}{l}\text { Carroll/UMich } \\
\text { Sachse/LaRC } \\
\text { Carroll/UMich } \\
\text { Blake/UCI } \\
\text { Heikes/URI } \\
\text { Heikes/URI }\end{array}$ & $\begin{array}{l}\text { Hoell et al. [1999] } \\
\text { Hoell et al. [1999] } \\
\text { Hoell et al. [1999] } \\
\text { Hoell et al. [1999] } \\
\text { Hoell et al. [1999] } \\
\text { Hoell et al. [1999] }\end{array}$ & $\begin{array}{c}\text { H-1min } \\
\text { H-1min } \\
\text { H-1min } \\
\text { H-HC } \\
\text { H-PER } \\
\text { H-PER }\end{array}$ \\
\hline
\end{tabular}

a Acronyms are defined in the text.

${ }^{b}$ Bendix, Chemiluminescence (commercial); CL, Chemiluminescence (with $\mathrm{C}_{2} \mathrm{H}_{4}, \mathrm{O}_{3}$ or NO); DACOM, Differential Absorption CO Measurement; DIAL, DIfferential Absorption LIDAR; ECC, Electro-chemical concentration cell; Enz. Fluor., Enzymatic Fluorimetry; GC/ECD, Gas chromatography/electron capture detector; GC/FID, Gas chromatography/flame ionization detector, GC/RGD, Gas chromatography/HgO reduction gas detector; Grab/GC, Canister grab samples/Gas chromatography; Grab/HPLC, Grab samples/High performance liquid chromatography; IR abs, Infrared absorption; Mist/IC, Mist chamber (aqueous scrubber)/ion chromatography; PF-TP/LIF, Photofragmentation (for NO 2 ); Res. Fluor., Resonance Fluorescence; SAE 1003, SA Environment model 1003AH (UV absorption); TEI 48, Thermo Environmental Instruments model 48 (IR absorption); TEI 49, Thermo Environmental Instruments model 49 (UV absorption); TP/LIF, Two-photon laser-induced fluorescence; UV abs, Ultraviolet absorption; Xe lamp, Photolytic conversion with xenon arc lamp; XeF laser, Photofragmentation of $\mathrm{NO}_{2}$.

${ }^{c}$ Overall uncertainty, estimated as the sum of the precision and systematic errors (calibration accuracy) when not stated in the literature.

dAmes, NASA Ames Research Center, CA; GIT, Georgia Institute of Technology; Harvard, Harvard University, MA; KFA, Jülich; LA, Laboratoire d'Aérologie de Toulouse, France; LaRC, NASA Langley Research Center, VA; MPI, Max Planck Institute; Nagoya, Nagoya University, Japan; NCAR, National Center for Atmospheric Research, CO; NOAA, National Oceanic and Atmospheric Administration; NOCAR, Carroll/NOAA and Ridley/NCAR ; PMEL, (NOAA) WA; UCI, University of California at Irvine; UMich, University of Michigan; UNH, University of New Hampshire; URI, University of Rhode Island; WFF, NASA Wallops Flight Facility, VA.

${ }^{\mathrm{e}} \mathrm{G}$ : GIT; L: L. Emmons; H: Harvard.

be a reliable technique over the past 15 years, therefore only the DACOM results have been included here. Ozone was measured by chemiluminescence.

The Stratospheric Ozone (STRATOZ) and Tropospheric Ozone (TROPOZ) campaigns were a collaboration of several French and German research groups. The two meridional experiments had similar tracks, circling the North Atlantic Ocean and South America, with STRATOZ-3 in June, 1984, including measurements of $\mathrm{O}_{3}, \mathrm{CO}$, and NO, and TROPOZ-2 in January, 1991, including measurements of $\mathrm{O}_{3}, \mathrm{CO}, \mathrm{NO}, \mathrm{PAN}, \mathrm{C}_{2} \mathrm{H}_{6}$, $\mathrm{H}_{2} \mathrm{O}_{2}$, and HCHO. [Ehhalt et al., 1992; Rohrer et al., 1997; Marenco and Said, 1989; Marenco et al., 1989; Marenco et al., 1995; Jonquières and Marenco, 1998]. In addition, regional experiments were performed between Europe and West Africa, with STRATOZ-3S during March, 1985 and TROPOZ-1 in December, 1987, and included measurements of $\mathrm{O}_{3}$ and $\mathrm{CO}$, with NO in addition during TROPOZ-1 [Marenco et al., 1990; Jonquières et al., 1998].
The GTE Amazon Boundary Layer Experiment (ABLE-2) included measurements over central Brazil of $\mathrm{O}_{3}, \mathrm{CO}$, and $\mathrm{NO}$ during the dry season (phase A) [Harriss et al., 1988] and of $\mathrm{O}_{3}, \mathrm{CO}, \mathrm{NO}$, and PAN during the wet season (phase B) [Harriss et al., 1990a]. Significant differences in the concentrations of observed species were seen during these two seasons due to biomass burning in the dry season and stronger biogenic emissions during the wet season. During the dry season (A) haze layers were observed which indicated long distance transport of biomass burning emissions from the savannah regions into the Amazon, adding to the local burning emissions. Transport of pollution from the Northern Hemisphere also influenced measurements during the wet season [Harriss et al, , 1990a].

CITE-2 included comparisons of $\mathrm{NO}, \mathrm{NO}_{2}, \mathrm{PAN}$, and $\mathrm{HNO}_{3}$ measurement techniques on flights over the western United States and eastern Pacific (see Hoell et al. [1990], and accompanying papers). Measurements of $\mathrm{NO}$ and $\mathrm{NO}_{2}$ were made by the NOCAR, WFF, and 
GIT groups. Observations of NO were made with the same instruments that were used in CITE-1, and all three groups again agreed well [Gregory et al., 1990a], so an average of these results were used in the current data composites. Observations of $\mathrm{NO}_{2}$ were made by the same three groups using three different techniques to dissociate $\mathrm{NO}_{2}$ to NO: photolysis with a broadband Xe arc lamp (NOCAR); chemical conversion with $\mathrm{FeSO}_{4}$ (WFF); and photofragmentation with a XeF excimer laser (GIT) [Gregory et al., 1990b]. The NOCAR and GIT observations correlated well, however the $\mathrm{FeSO}_{4}$ technique (WFF) had significant interference from additional species (e.g., PAN) [Gregory et al., 1990b], so an average of NOCAR and GIT data has been used. PAN measurements were made by groups from Ames and NCAR both using gas chromatography with electroncapture detection (GC/ECD) [Gregory et al., 1990c]. These results also agreed fairly well, so the average of the two was used in the data composites. Three methods were compared for the measurement of $\mathrm{HNO}_{3}$, including a denuder technique, nylon filter grab sampling, and a tunable diode laser system (TDLAS) [Gregory et $a l ., 1990 \mathrm{~d}]$. The lack of agreement between these techniques has prevented use of them in the composites.

A series of ozonesondes were launched from the ice-breaker supply ship, R/V Shirase, for 4 years (1987-1990) between Japan and Syowa station, Antarctica. Each year the ship left Japan about November 15 and arrived about December 15 , with sondes launched roughly every other day [Matsubara et al., 1991; Japan Meteorological Agency, 1995]. Each year shows high levels of $\mathrm{O}_{3}$ in the eastern Indian Ocean, which analysis with a global 3-D chemical transport model (MOZART) suggests is produced over Africa from lightning-generated $\mathrm{NO}_{x}$ [Emmons et al., 1998; D.A. Hauglustaine et al., On the role of lightning $\mathrm{NO}_{x}$ in the formation of tropospheric ozone plumes in the tropics, submitted to Journal of Atmospheric Chemistry, 2000].

The GTE Arctic Boundary Layer Expeditions (ABLE-3A and -3B) were both conducted in the summer, with phase A in Alaska [Harriss et al., 1992a] and phase $\mathrm{B}$ over Labrador and Ontario [Harriss et al., 1994a]. Measurements of $\mathrm{O}_{3}, \mathrm{CO}, \mathrm{NO}, \mathrm{NO}_{2}, \mathrm{PAN}$, NMHCs, and lidar $\mathrm{O}_{3}$ profiles during ABLE-3A and the same species, plus acetone, during ABLE-3B have been included in these data composites. The meteorological conditions during ABLE-3A were warmer and dryer than normal resulting in a greater frequency of fires, and the sampled air masses were frequently from Siberia and the North Pacific [Shipham et al., 1992]. During ABLE$3 \mathrm{~B}$ the weather was warmer and wetter than normal, and air masses had a combination of sources, including the stratosphere, smoke from fires in Alaska and Canada, midlatitude Pacific (with low $\mathrm{O}_{3}$ ), and pollution from the United States and Asia [Shipham et al., 1994].
NASA's Airborne Arctic Stratospheric Expeditions (AASE-1 and 2) used the ER-2 and DC-8 aircraft to study the winter-spring arctic stratospheric ozone depletion in 1989 and 1992. Measurements from the DC-8 of $\mathrm{O}_{3}, \mathrm{NO}$, and $\mathrm{NO}_{x}$ during AASE- 1 and of $\mathrm{O}_{3}, \mathrm{CO}$, and NO during AASE-2 have been included in the current data composites (stratospheric and tropospheric data have not been separated, as explained above). The flights during AASE-1 were concentrated between Norway and Greenland, and poleward, mainly above $10 \mathrm{~km}$ altitude [Turco et al., 1990]. During AASE-2, however, flights were made to Puerto Rico and Tahiti, in addition to arctic measurements from bases in Alaska, Maine, and Norway [Anderson and Toon, 1993; Wofsy et al., 1994].

International Stratospheric Air Chemistry (INSTAC) consisted of a series of flights between Japan and Indonesia in March 1989 [Kondo et al., 1993]. Measurements of $\mathrm{O}_{3}$ and NO were made, showing a latitudinal gradient with very low values near the equator increasing at midlatitudes where outflow from Asia influenced the sampled air masses [Kondo et al., 1993].

Electrified Cloud Chemistry (ELCHEM) was a study of the production of $\mathrm{NO}_{x}$ in thunderstorms over New Mexico during July and August, 1989 [Ridley et al., 1994]. Measurements of $\mathrm{NO}, \mathrm{NO}_{2}$, and $\mathrm{O}_{3}$ were made from the NCAR Sabreliner jet aircraft around and within deep convective cloud systems, some of which were electrically active, as well as in fair, high-pressure conditions. This sampling strategy provided observations covering the wide range of values expected during this season. Very high values of NO (2 ppbv) were observed in the anvils of convective systems in the upper troposphere, accompanied by high ozone levels, whereas during fair weather very low mixing ratios of $\mathrm{O}_{3}, \mathrm{NO}$, and $\mathrm{NO}_{x}$ were observed throughout the troposphere [Ridley et al., 1994].

GTE/CITE-3 consisted of two series of flights, the first over the western North Atlantic near Virginia in August, and the second near Brazil in September, 1989 [Hoell et al., 1993]. Although the focus of the intercomparison was on several sulfur compounds, $\mathrm{O}_{3}, \mathrm{CO}$, $\mathrm{NO}$, and $\mathrm{NO}_{2}$ were also observed, and these observations have been included in the data composites. The observations over the North Atlantic were influenced by anthropogenic pollutants from the eastern United States [Anderson et al., 1993a], while the data near South America showed emissions from biomass burning in the region [Anderson et al., 1993b].

The GTE Pacific Exploratory Mission-West (PEM-West) included two phases, PEM-West-A in September-October, 1991 [Hoell et al., 1996] and PEM-West-B during February-March, 1994 [Hoell et al., 1997], both of which took place over the western North Pacific. Measurements of $\mathrm{O}_{3}, \mathrm{CO}$, NO, PAN, $\mathrm{HNO}_{3}, \mathrm{NMHCs}, \mathrm{H}_{2} \mathrm{O}_{2}, \mathrm{CH}_{3} \mathrm{OOH}$, and $\mathrm{O}_{3}$ profiles by lidar were made during both phases. During PEM- 


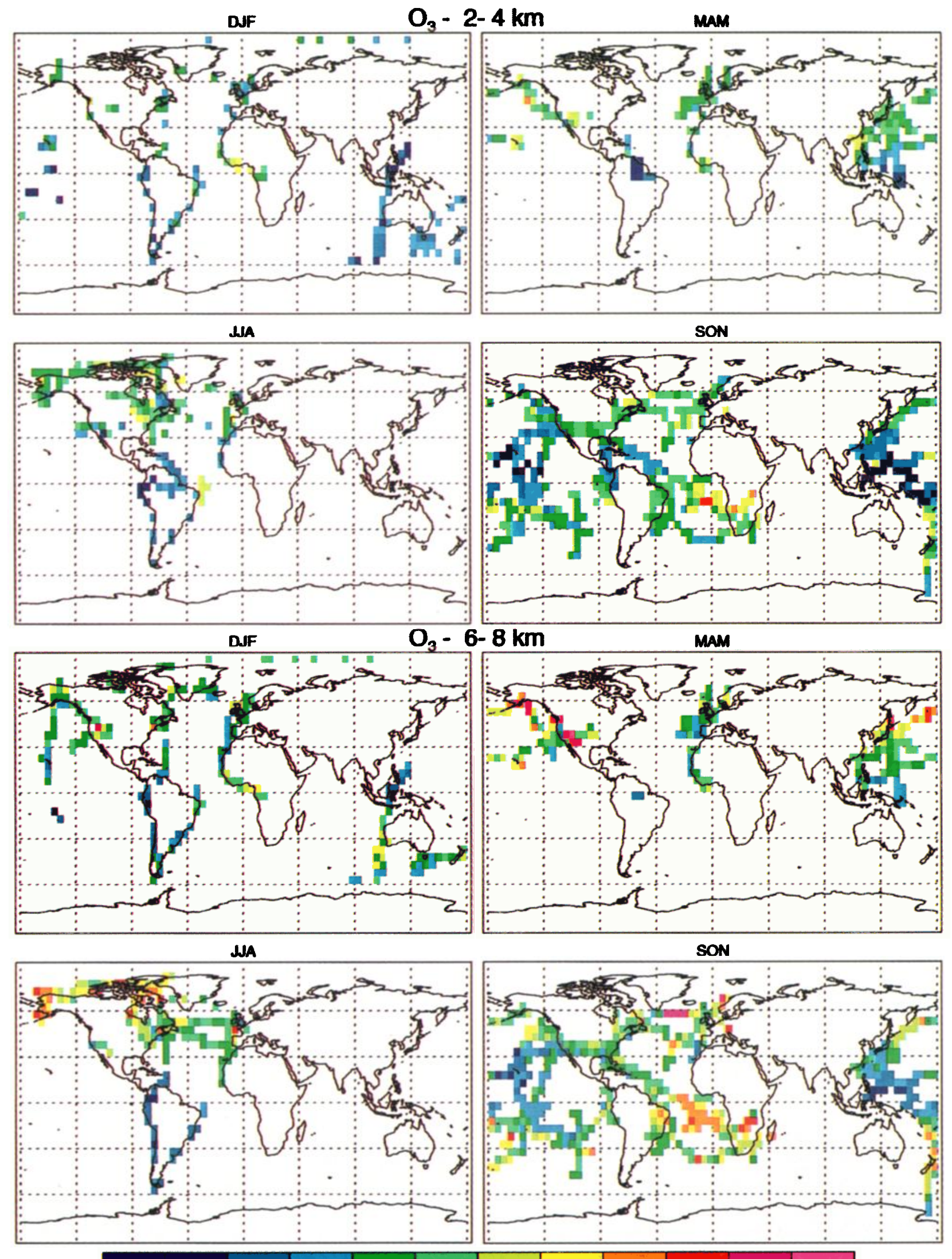

0. 10. 20. 30. 40. 50. 60. 70. 80. 90. 100. $150 . \quad$ ppbv

Plate 1. $\mathrm{O}_{3}$ data composites for 2-4 km (top four panels) and 6-8 km (bottom four panels). The observations are sorted into four seasons. 

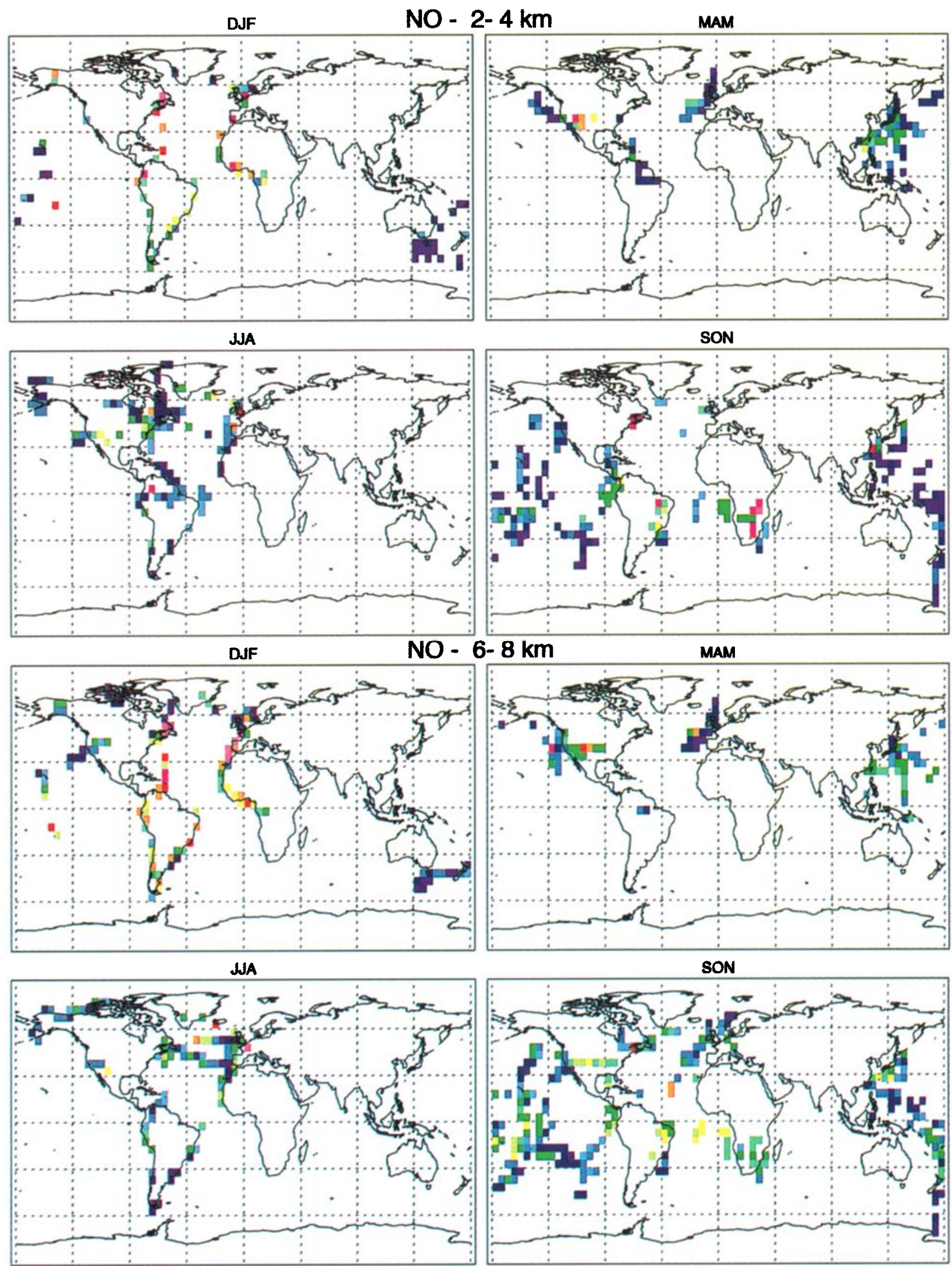

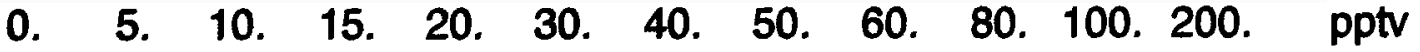

Plate 2. NO composites for 2-4 and 6-8 km. These observations are associated with solar zenith angles less than $90^{\circ}$. 


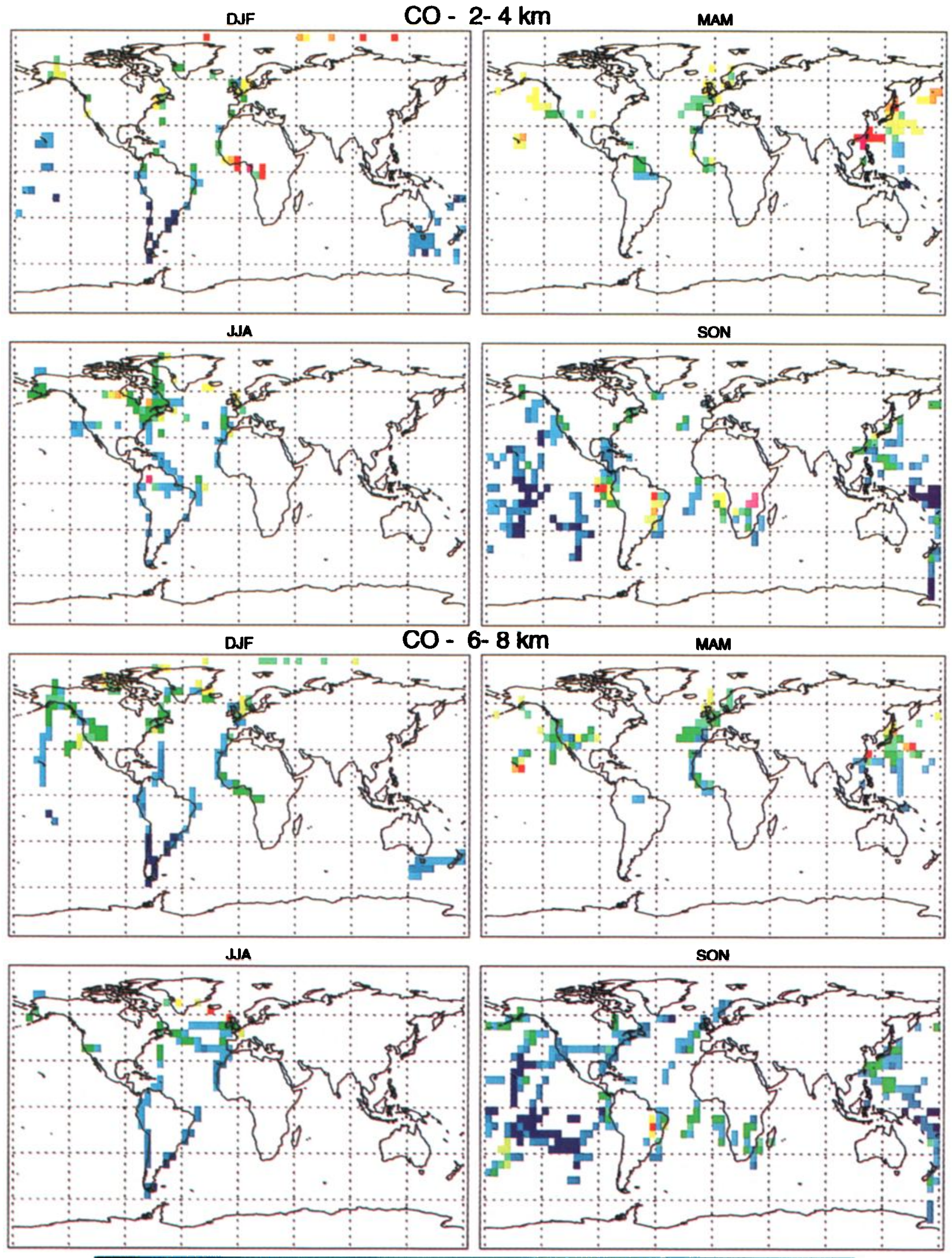

0. 40. 60.80 .100 .120 .140 .160 .180 .200 .250 .300 . $14 p b v$

Plate 3. CO composites for $2-4$ and $6-8 \mathrm{~km}$. 

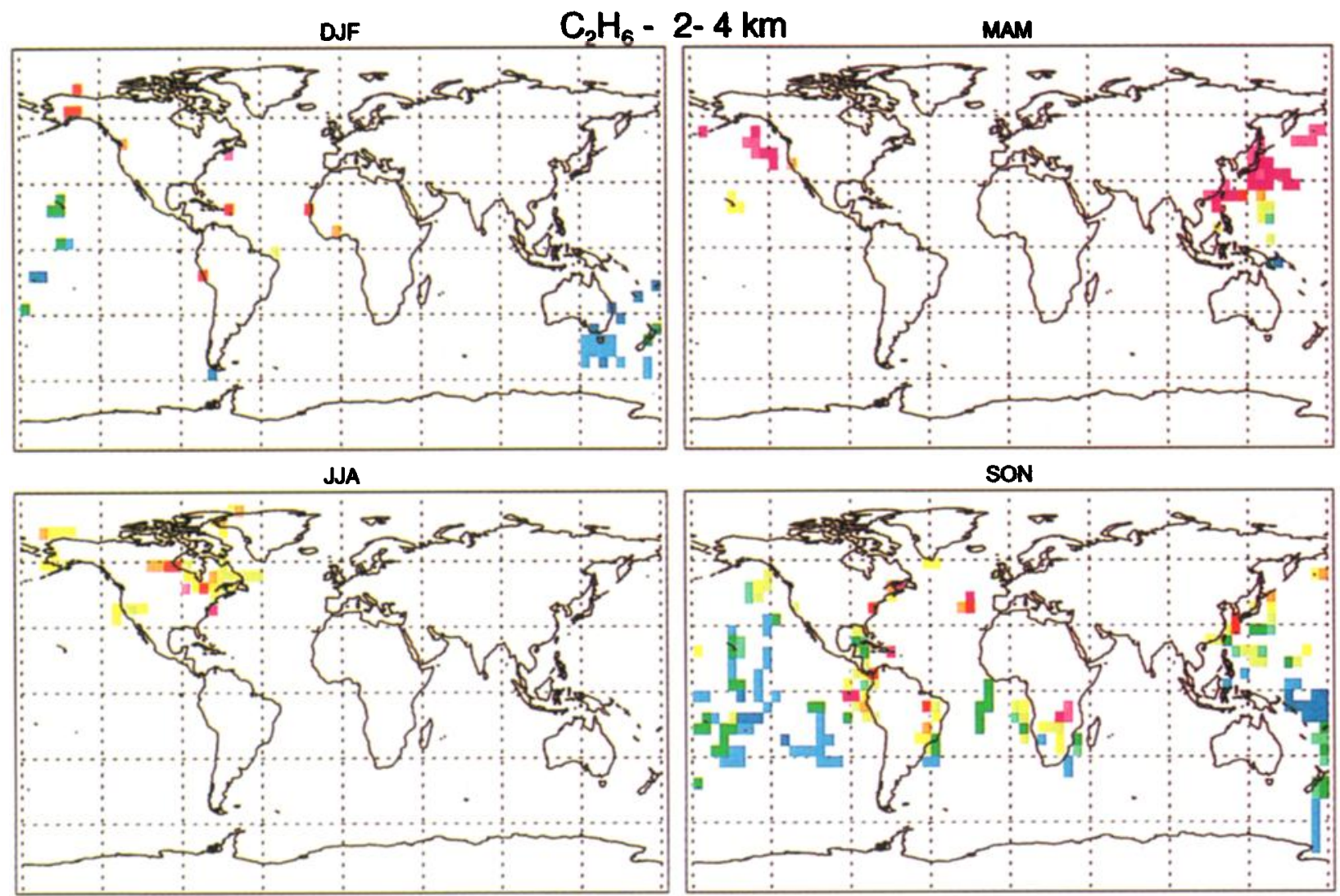

DJF

\section{$\mathrm{C}_{2} \mathrm{H}_{6}-6-8 \mathrm{~km}$}

MAM
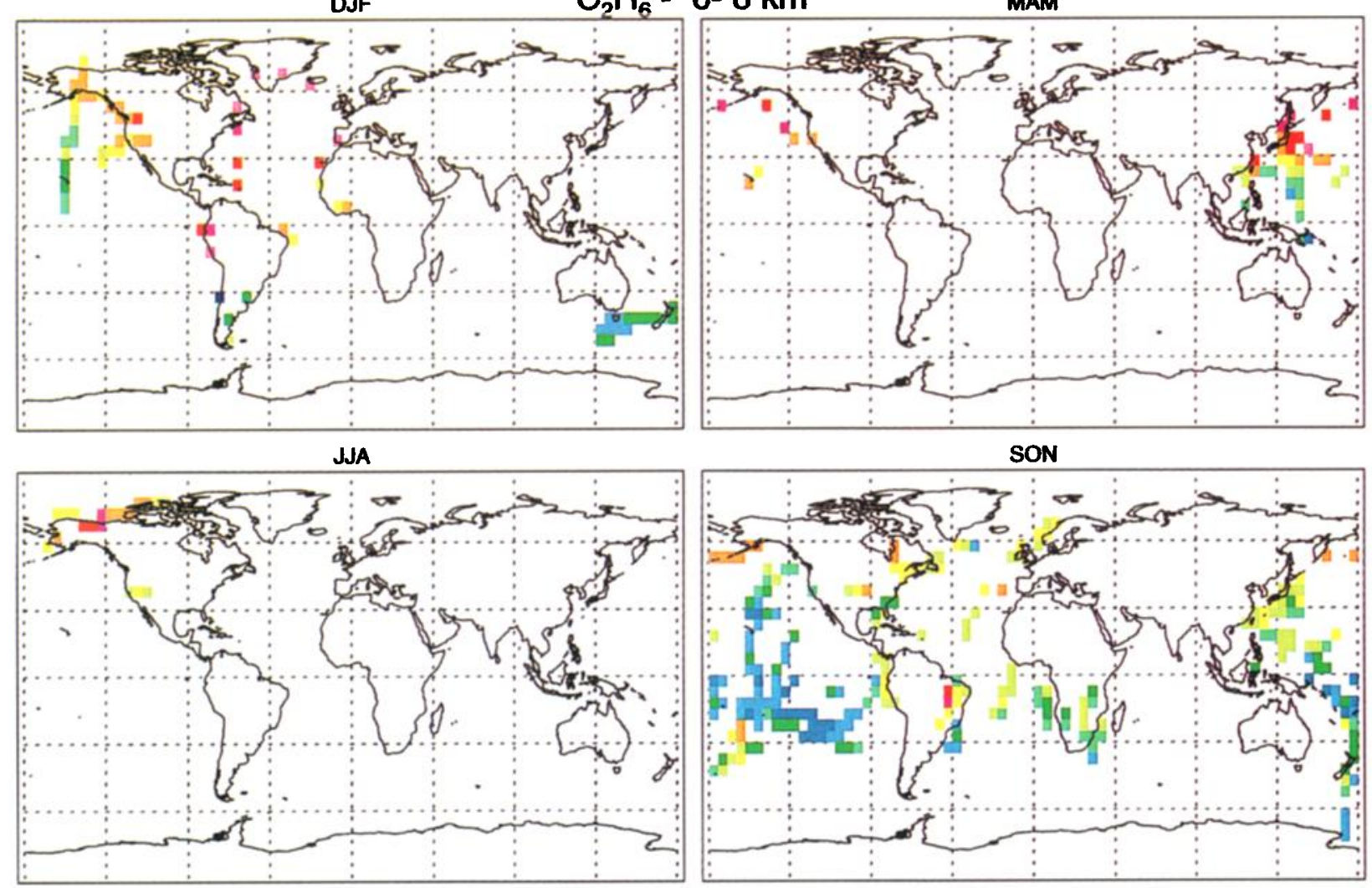

0. 100. 200. 300. 400. 500. 600. 800.1000.1200.1500.2000. pptv

Plate 4. $\mathrm{C}_{2} \mathrm{H}_{6}$ composites for $2-4$ and $6-8 \mathrm{~km}$. 
West-B, measurements of acetone were also made. NO was measured with two techniques (chemiluminescence and TP/LIF) during both phases, which agreed well so an average of the two observations has been used in the composites. Box model calculations, constrained by observations, were made of 24 -hour average ozone production and loss rates [Crawford et al., 1996]. The observed $\mathrm{NO}_{2}$ mixing ratios greatly differed from the values produced by the box model, suggesting the measurements were affected by an interferent [Crawford et al., 1996], therefore the calculated $\mathrm{NO}_{x}$ values have been used here. The two different seasons allowed a comparison of differing flow regimes, with phase A during flow predominantly from the ocean onto Asia, and phase B during strong outflow conditions. September-October 1991 had near-average tropical cyclone activity with 6 cyclones forming during the measurement campaign, including one tropical storm, three typhoons, and two supertyphoons [Bachmeier et al., 1996]. Although widespread influence of cyclones is a characteristic of this period in the western Pacific, the chemical measurements may not be climatologically representative, as the precise locations of storms affected continental outflow or transport of clean tropical air to the sampled region. The circulation patterns during PEM-West-B were near normal. A cold phase El Niño-Southern Oscillation (ENSO) began to form during the winter 1993-1994 with rainfall below normal over interior China and above normal in Indonesia [Merrill et al., 1997].

The Mauna Loa Observatory Photochemistry Experiment (MLOPEX-2) included aircraft flights around Hawaii, in addition to extensive surface measurements near the top of Mauna Loa [Atlas and Ridley, 1996]. Measurements of $\mathrm{O}_{3}, \mathrm{CO}$, NMHCs, $\mathrm{H}_{2} \mathrm{O}_{2}$, and $\mathrm{CH}_{3} \mathrm{OOH}$ were made from the University of Wyoming King Air [Ridley et al., 1997]. Back trajectories indicate much of the air sampled had passed over Asia, and was transported at high altitudes before descent over Hawaii $[R i$ dley et al., 1997].

The GTE Transport and Atmospheric Chemistry near the Equator-Atlantic (TRACE-A) campaign took place over South America, the South Atlantic Ocean and southern Africa during the Southern Hemisphere dry season and included measurements of $\mathrm{O}_{3}, \mathrm{CO}, \mathrm{NO}$, PAN, $\mathrm{HNO}_{3}$, NMHCs, $\mathrm{H}_{2} \mathrm{O}_{2}, \mathrm{CH}_{3} \mathrm{OOH}, \mathrm{CH}_{3} \mathrm{COCH}_{3}$, and HCHO [Fishman et al., 1996]. Box model calculations of 24-hour average ozone production and loss rates and $\mathrm{NO}_{x}$ mixing ratios have also been included in the data composites (J. Crawford, personal communication, 1998; GTE ftp site). The meteorological conditions during the campaign were much warmer than average due to a particularly long ENSO event, with severe drought in southern Africa, warm, dry conditions over northeastern Brazil and cool, wet conditions in central South America. Nonetheless, the large-scale tropospheric flow was similar to the climatological average [Bachmeier and Fuelberg, 1996]. Although the campaign was after the peak in biomass burning in Brazil, the aircraft sampled convective transport of burning emissions on one flight over eastern Brazil [Fishman et al., 1996]. In Africa, burning was also reduced due to the drought, but large numbers of fires were seen in the region between $10^{\circ}$ and $20^{\circ} \mathrm{S}$, and clearly influenced the observations both over Africa and the South Atlantic [Fishman et al., 1996].

Oxidizing Capacity of the Tropospheric Atmosphere (OCTA), a European research project, included flights of a C-130 over the northern Atlantic and England during four periods. The summer 1993 campaign was part of the International Global Atmospheric Chemistry (IGAC) North Atlantic Regional Experiment (NARE 1993) [Gerbig et al., 1996]. $\mathrm{O}_{3}, \mathrm{CO}$, and NO were measured during each campaign. The observations showed layers of high levels of pollutants both near North America and Europe, with evidence of long-range transport over the central Atlantic in less distinct layers [Gerbig et al., 1996].

The first Aerosol Characterization Experiment (ACE-1), a component of IGAC, used the NCAR C-130 for observations on the transit across the Pacific from North America to Tasmania where the main portion of the campaign was conducted [Bates et al., 1998]. The data composites include measurements of $\mathrm{O}_{3}, \mathrm{CO}, \mathrm{NO}$, NMHCs, $\mathrm{H}_{2} \mathrm{O}_{2}$, and $\mathrm{CH}_{3} \mathrm{OOH}$, as well as ozonesondes launched from the research vessel Discoverer as part of this campaign.

The Tropical and Vortex Ozone Transport Experiments (TOTE and VOTE) were a pair of NASA campaigns using the NASA DC-8 to study small scale features in ozone and methane and the transport of ozone from the tropics and polar regions to midlatitudes. Flights were mainly over the eastern Pacific from the equator to the north pole, in December 1995 to February 1996, and included measurements of $\mathrm{O}_{3}, \mathrm{CO}$, and NO.

The Subsonic Aircraft: Contrail and Cloud Effects Special Study (SUCCESS), sponsored by NASA/Subsonic Assessment program (SASS), used several aircraft to study the effects of aircraft exhaust and clouds over the central US [Toon and Miake-Lye, 1998]. Measurements of $\mathrm{O}_{3}, \mathrm{CO}$, and $\mathrm{NO}$ made from the DC-8 have been included in this work. Correlations between observed species (e.g., $\mathrm{CO}$ and $\mathrm{NO}_{y}$ ) indicated aircraft plumes, lightning emissions, and convected boundary layer emissions were observed [Jaeglé et al., 1998].

The GTE Pacific Exploratory Mission in the Tropics (PEM-Tropics-A) included observations from two aircraft over the tropical Pacific during August-October, 1996 [Hoell et al., 1999]. Observations from both the P-3 and DC-8 included $\mathrm{O}_{3}, \mathrm{CO}$, NO, NMHCs, $\mathrm{H}_{2} \mathrm{O}_{2}$, and $\mathrm{CH}_{3} \mathrm{OOH}$, and in addition from the DC-8 included $\mathrm{NO}_{x}, \mathrm{PAN}, \mathrm{HNO}_{3}$, and $\mathrm{O}_{3}$ profiles. Two different box 
model calculations were run for the DC-8 observations, and the two results for ozone production and loss rates are included in the data composites [Schultz et al., 1999; J. Crawford, personal communication, 1999]. From comparison to an 11-year average of sea surface temperature, sea level pressure, and winds, it appears that this period was in a neutral or a weak La Niña phase, but the airflow patterns were generally climatological [Fuelberg et al., 1999].

\subsection{Measurement Techniques}

A summary of the measurement techniques used in each campaign, along with the estimated uncertainties, are given in Table 2. Details of each technique used will not be given here and readers are directed to the references given above and in Table 2 for specific campaigns. Following are some general comments about the data and techniques used that should be kept in mind when using the data composites.

The relatively large concentrations of ozone found in the troposphere (10-100 ppbv) have allowed for quite reliable and precise in situ measurements to be made, with a variety of instrument types (UV absorption, electrochemical cell, and ethylene or nitric oxide chemiluminescence) appropriate for different platforms (ground, balloon, and aircraft). The Differential Absorption Lidar (DIAL) has allowed measurement of ozone profiles above and below the aircraft, greatly increasing the number of $\mathrm{O}_{3}$ observations for a given flight. The DIAL measurements have been verified to agree with coincident in situ observations [e.g., Browell et al., 1992, 1994].

$\mathrm{CO}$, with mixing ratios in the tens to hundreds of ppbv, has also been measured precisely from aircraft. The DACOM instrument, a tunable diode laser system used for many of the $\mathrm{CO}$ measurements presented here, has agreed well with grab samples analyzed by GC in formal and informal intercomparisons [Hoell et al., 1987b; Harriss et al., 1992b].

Most of the other species discussed here have levels in the pptv range in the free troposphere, and their measurement is therefore far more difficult. An added difficulty is that aircraft measurements require a fast response time in order to provide meaningful results. From both formal (CITE-1, -2) and informal (PEM-West) intercomparisons, the chemiluminescence and two-photon/laser-induced fluorescence measurements of NO seem to be generally reliable [e.g., Hoell et al., 1990, 1997]. However, there are concerns of interferents and inlet line losses with the measurements of $\mathrm{NO}_{2}$, and disagreements between observations and box model calculations are not fully understood [e.g., Ridley et al., 1988; Crawford et al., 1996]. $\mathrm{NO}_{2}$ measurements during PEM-Tropics-A with a new photofragmentation method, however, agree well with box model calculations [Bradshaw et al., 1999].

PAN has been measured using gas chromatography and electron capture detection for a number of years by various groups, without major discrepancies [e.g., Hoell et al., 1990; Singh et al., 1998]. However, this is the only technique used in the composites here, which limits the ability of intercomparisons to uncover errors [Crosley, 1994]. The intercomparison of $\mathrm{HNO}_{3}$ techniques during CITE-2 showed large disagreements between three techniques (as mentioned above) [Gregory et al., 1990d], but there have not been subsequent aircraft comparisons to determine the most accurate techniques. Thus, the data composites currently only include measurements with the mist chamber/ion chromatography technique [e.g., Talbot et al., 1994]. $\mathrm{HNO}_{3}$ is an extremely "sticky" molecule, and great care must be taken to reduce and account for losses in inlets [Crosley, 1994, 1996; Bradshaw et al., 1998].

It has been found that care must be taken in the use of canister samples for hydrocarbons, and in particular to prevent erroneous measurements of alkenes [e.g., Blake et al., 1992]. Although recent measurements of all reported NMHCs are expected to be reliable with careful canister handling [e.g., Blake et al., 1994], only observations of $\mathrm{C}_{2} \mathrm{H}_{6}$ and $\mathrm{C}_{3} \mathrm{H}_{8}$ are included in this analysis.

Peroxides $\left(\mathrm{H}_{2} \mathrm{O}_{2}\right.$ and $\left.\mathrm{CH}_{3} \mathrm{OOH}\right)$ have been measured by a number of groups using a high performance liquid chromatographic (HPLC) fluorimetric method on grab samples [e.g., O'Sullivan et al., 1999]. Comparison of four techniques to measure $\mathrm{H}_{2} \mathrm{O}_{2}$ were made on the ground during MLOPEX-2. Three used enzyme catalyzed dimerization of p-hydroxyphenylacetic acid with fluorescence detection, while one used a tunable diode laser system (TDLAS). Good agreement (20\%) among all the techniques was seen for extended periods; however, periods of persistent disagreement were also observed, without an explanation found [Staffelbach et al., 1996].

Formaldehyde (HCHO) has a very short lifetime in summer ( $\sim 5$ hours) making it difficult to measure in the free troposphere away from sources. Analysis using HPLC was used by two different groups (Jülich and URI) for the small amount of HCHO data presented here [Arlander et al., 1995; Heikes et al., 1996]. An informal intercomparison of five methods was made on Mauna Loa during MLOPEX-2, where discrepancies in blanks and calibrations were identified as the main source of differences between the URI measurements and similar techniques [Heikes et al., 1996]. Comparisons of observations with box model calculations show an overestimation of the models by a factor of 2-3, indicating the chemistry of $\mathrm{HCHO}$ in the remote troposphere is not completely understood [Jacob et al., 1996; Hauglustaine et al., 1999].

Acetone $\left(\mathrm{CH}_{3} \mathrm{COCH}_{3}\right)$ is also difficult to measure at the levels present in the free troposphere, so there are few measurements to include in these composites. Measurements were made with the NASA Ames PAN/Aldehyde/Ketone (PANAK) GC instrument during three campaigns (ABLE-3B, TRACE-A, PEMWest-B) [Singh et al., 1994b]. 


\subsection{Data Files}

Complete data files of the observations and box model calculations from the NASA GTE campaigns are available on the NASA Langley Data Archive which can be accessed from the GTE web site (http://www-gte.larc.nasa.gov/). Data from the AASE, SUCCESS, MLOPEX, and OCTA campaigns have been released on CD. The ACE-1 observations are available from the UCAR/CODIAC data server (http://www.joss. ucar.edu/codiac/). Additional data (e.g., INSTAC), as well as merged files, are available from the UMSASS Data Archive, which can be accessed through the data composites web site (http://aoss.engin.umich.edu/SASSarchive/).

In order to calculate the averages and statistics for each $5^{\circ}$ by $5^{\circ}$ grid box and profile region, "merged" data files were used, where the measured parameters are averaged to a common time base. The merged data files from Georgia Tech and Harvard (available from the GTE web site), with various averaging times, were used in a number of cases (as specified in Table 2). In these merges, lower frequency data are repeated in the file for the duration of the sampling time, and using these data for this sort of analysis can lead to erroneous averaging and counting of observations in a region or grid cell. Therefore different merges were used for different species. In many cases, new 1-min average merged files were created, where data measured more frequently $\left(\mathrm{O}_{3}, \mathrm{CO}, \mathrm{NO}\right)$ were averaged to $1 \mathrm{~min}$ and slower frequency data (PAN: $150 \mathrm{~s}, \mathrm{HNO}_{3}: 5-25 \mathrm{~min}, \mathrm{H}_{2} \mathrm{O}_{2}$ and $\mathrm{CH}_{3} \mathrm{OOH}: 5 \mathrm{~min}, \mathrm{HCHO}: 60 \mathrm{~s}, \mathrm{CH}_{3} \mathrm{COCH}_{3}: 130 \mathrm{~s}$, NuIHCs: $5 \mathrm{~min}$ ) were recorded only at the midpoint of the measurement with the length of the averaging time also recorded. Observations reported beiow the specified detection limit were set to half of the detection limit. For the computed ratios. PAN/NO $x$ was calculated if the midpoints were within $1 \mathrm{~min}$ of each other, and for $\mathrm{HNO}_{3} / \mathrm{NO}_{x}, \mathrm{NO}_{x}$ was averaged over the period of the $\mathrm{HNO}_{3}$ sample. $\mathrm{H}_{2} \mathrm{O}_{2}$ and $\mathrm{CH}_{3} \mathrm{OOH}$ were always sampled simultaneously, so the ratio $\mathrm{H}_{2} \mathrm{O}_{2} / \mathrm{CH}_{3} \mathrm{OOH}$ was calculated whenever there were valid measurements of both species. $\mathrm{C}_{3} \mathrm{H}_{8}$ and $\mathrm{C}_{2} \mathrm{H}_{6}$ were also measured simultaneously. The ratios were calculated for each observation, and the the statistics of each region or grid box were computed. The ratios of the model results are treated similarly.

\section{Data Composites}

The data sets discussed above have been grouped in two different ways. In the first case, all of the observations for each campaign were grouped into $5^{\circ}$ latitude by $5^{\circ}$ longitude by $1 \mathrm{~km}$ altitude grid boxes and the statistics of the data (minimum, maximum, median, mean and standard deviation, quartiles, and number of observations) were determined. The $5^{\circ}$ grid was chosen so as to resolve relatively small scale variations while having a sufficient number of observations for reasonable statistics. The gridded data for individual campaigns can be examined, or data can be combined for each season and averaged over arbitrary altitudes to form "data composites." The second set of data groupings provides vertical profiles for selected regions of individual campaigns, where the statistics for a $10^{\circ}-$ $20^{\circ}$ box are determined at each kilometer in altitude. These "data composites" are available on the Internet at http://aoss.engin.umich.edu/SASSarchive/ in a variety of forms, including plots of gridded maps and the data files for individual campaigns. The availability of each campaign separately allows for them to be used for evaluation of models run for specific years. Links to the original data sets and additional information about the measurements and the campaigns, as well as figures that could not be included in this paper, are also available on the web site.

When using these data composites, it is important to keep in mind that each grid box generally only represents a single campaign. and actually only from a short time period. Because of the scarcity of the data, many grid boxes contain only a few observations and the statistics are poor. Each of the campaigns were also focused on particular regions and processes (e.g., convective outflow, biomass burning emissions), which may bias the observations from the average concentrations at that location. Our goal is to compile all of the observations, without filtering for "plumes" or what might be considered abnormal events. Use of the median of each grid box (discussed below) reduces the effect of wide excursions in the data, as well.

\subsection{Global Maps}

Several examples of global maps of gridded data are shown in Plates 1-4, with campaigns sorted by season. In these plots, each grid cell is the average, weighted by the number of observations, of the median values of the $5^{\circ} \times 5^{\circ}$ grid cell for each campaign at that location and season over the specified altitude range. These maps show the observations for $2-4 \mathrm{~km}$ and $6-8 \mathrm{~km}$, which in this discussion are referred to as lower and middle troposphere, respectively. Observations from the upper troposphere $(10-11 \mathrm{~km})$ are shown in a later section.

The distributions of ozone at 2-4 and 6-8 km, including both in situ and DIAL measurements, are shown in Plate 1. Although the measurements are generally sparse, and the coverage varies with altitude and season, some seasonal and vertical trends can be seen. At high latitudes, the ozone mixing ratios are higher at $6-8 \mathrm{~km}$ than $2-4 \mathrm{~km}$, partially due to the influence of stratospheric air, strongest in winter when the tropopause is lowest there (e.g., measurements from AASE). In other locations in the middle troposphere, the effect of convection of precursors on $\mathrm{O}_{3}$ production from the surface and lightning-produced $\mathrm{NO}_{x}$ can be seen in the high levels of $\mathrm{O}_{3}$ (e.g., over the South At- 
lantic in SON during TRACE-A [Smyth et al., 1996]). As well, $40-80$ ppbv $\mathrm{O}_{3}$ is seen along the west coast of Australia in DJF in the upper troposphere (from the Shirase measurements), likely due to lightning production of $\mathrm{NO}_{x}$ and biomass burning over Africa [Emmons et al., 1998; D.A. Hauglustaine et al., On the role of lightning $\mathrm{NO}_{x}$ in the formation of tropospheric ozone plumes in the tropics, submitted to Journal of Atmospheric Chemistry, 2000]. During June-August, high ozone levels are evident over North America in both the lower and middle troposphere, over the far northern regions where stratospheric and biomass burning influences were strong (ABLE-3A) [Shipham et al., 1992], as well as over the United States where anthropogenic sources and lightning play a dominant role in ozone formation (CITE-2, -3, ABLE-3A, -3B) [e.g., Shipham et $a l .$, 1994]. There have been three major GTE campaigns during September and October (PEM-West-A, TRACE-A, PEM-Tropics-A) that have provided a significant amount of data for the South Atlantic and $\mathrm{Pa}$ cific basins. In the $\mathrm{SON}$ panel, $40-80 \mathrm{ppbv}$ of $\mathrm{O}_{3}$ appears in the Southern Hemisphere at both 2-4 and 6$8 \mathrm{~km}$, largely due to biomass burning in Africa and South America (TRACE-A, PEM-Tropics-A) [Hoell et al., 1999, and references therein]. The maximum over the South Atlantic has also been observed in TOMS tropospheric column retrievals [Fishman and Brackett, 1997; Ziemke et al., 1998; Hudson and Thompson, 1998]. In the northern tropics, $\mathrm{O}_{3}$ levels are $10-30 \mathrm{ppbv}$ where transport from source regions is slow and there is little or no photochemical production (PEM-TropicsA, PEM-West-A). Near North America and Asia some higher levels are seen, transported from regions of anthropogenic influence (OCTA, PEM-West-B).

There are significantly fewer observations of NO (Plate 2) than of $\mathrm{O}_{3}$, a reflection of the greater difficulty of measuring $\mathrm{NO}$, as well as the greater coverage provided by the DIAL $\mathrm{O}_{3}$ measurements. Ambient levels of NO are highly variable and the observations cover a wide range of values. This is largely due to the fact that NO is emitted directly from sources and has a very short lifetime, though NO is generally in steady state with $\mathrm{NO}_{2}$ within a few minutes after being emitted. It also has a strong diurnal cycle, being completely converted to $\mathrm{NO}_{2}$ at night. However, the measurements of $\mathrm{NO}$ are less prone to interferences than $\mathrm{NO}_{2}$ [e.g., Crawford et al., 1996], and are often measured without simultaneous $\mathrm{NO}_{2}$ observations or other coincident measurements to allow box model calculations of $\mathrm{NO}_{2}$ to be made. We have chosen to present in Plate 2 the distributions of NO (from measurements made when SZA $<90^{\circ}$ ). The $\mathrm{NO}_{2}$ photolysis rate, and therefore $\mathrm{NO} / \mathrm{NO}_{2}$, is not very sensitive to SZA $\left(<80^{\circ}\right)$ [e.g., Hauglustaine et al., 1999; Ruggaber et al., 1994], therefore the measurements presented here should be minimally affected by SZA.

The high variability in NO observations is seen during all seasons in both the lower and middle troposphere. In the lower troposphere, higher mixing ra- tios are seen over and downwind of continents, showing the influence of anthropogenic emissions from North America and Asia (SUCCESS and PEM-West-B during MAM, CITE-2 and ABLE-3A, -3B during JJA), and of biomass burning in Africa and South America during September-November (TRACE-A). Over the oceans, however, NO levels are frequently below $10 \mathrm{pptv}$, such as in SON during PEM-Tropics-A. In the middle troposphere some of the same patterns are apparent, except that higher values are seen over the oceans, particularly the South Pacific and South Atlantic during September-November. These higher mixing ratios are from biomass burning emissions that have been convected as $\mathrm{NO}_{x}$ or reservoirs, or from lightning-produced $\mathrm{NO}$, and then have been transported from the continents (PEM-Tropics-A and TRACE-A) [e.g., Smyth et al., 1996].

Plates 3 and 4 show the observations of $\mathrm{CO}$ and $\mathrm{C}_{2} \mathrm{H}_{6}$ for the same altitudes. There are fewer $\mathrm{C}_{2} \mathrm{H}_{6}$ data than $\mathrm{CO}$ because of the coarser sampling required for the measurements of $\mathrm{C}_{2} \mathrm{H}_{6}$. Carbon monoxide and ethane have similar emission patterns as the surface emissions of NO, having industrial and biomass burning sources [e.g., Müller, 1992], and consequently show similar distributions in the lower troposphere. However, since $\mathrm{CO}$ and $\mathrm{C}_{2} \mathrm{H}_{6}$ have longer lifetimes (1-2 months and less than 1 month, respectively, in summer), the distributions differ away from sources. The highest values of both species are seen at 2-4 km over North America in summer (ABLE-3), downwind of Asia in early spring (PEM-West-B), and over southern Africa and South America during September-November (TRACEA). Low values are observed over the central Pacific at both altitudes (PEM-West-A, PEM-Tropics-A). In most locations lower values of $\mathrm{CO}$ and $\mathrm{C}_{2} \mathrm{H}_{6}$ are seen in the middle troposphere than close to the ground, except in regions far from the sources where the emissions have been transported (such as over the South Pacific during PEM-Tropics-A). Relatively high values are seen in the western South Pacific at 6-8 km in SON, which back trajectories indicate come from biomass burning in Africa and Australia [Fuelberg et al., 1999]. High levels of $\mathrm{CO}$ are seen in the northern polar regions, associated with the winter-spring maximum in ozone and its precursors [Penkett and Brice, 1986; Yienger et al., 1999].

\subsection{Vertical Profiles}

The $5^{\circ} \times 5^{\circ}$ global maps can be compared with similar maps of global model output; however, it can be difficult to quantify their differences, due to the paucity of data and sharp gradients between grid boxes in the data composites. Therefore we have selected several regions from individual campaigns to examine vertical profiles, as used by Hauglustaine et al. [1998], and similar to other studies [cf. Wang et al., 1998; Thakur et al., 1999]. The selection of these regions was based primarily on the availability of data at all altitudes, though 
the spatial variation in ambient levels and meteorological conditions were also considered. Although these profiles represent only a small fraction of the data in the composites, they provide a different perspective on the distribution of species from the gridded maps and are valuable for comparison with model results. The resolution of the models does not allow simulation of small-scale features, but average distributions, as represented by profiles in these regions, should be reproduced if the models have the general meteorology of the time of the observations. The regions wherein profiles were examined are shown in Figure 1, and identified in Table 3. As examples, measurements for three regions are presented, which show the effects of biomass burning (Africa), industrial pollution (Asia coast), and remote regions (central Pacific).

Profiles for the "Africa_S" region from TRACE-A are shown in Figure 2. The data within each kilometer altitude in the region are represented by box and whisker plots, with the number of observations at each altitude listed (solid and dashed lines are model results, which are discussed in section 5). Although there is great variability in the data within this region, due to observations made near and away from fires [Fishman et al., 1996; J. Logan, personal communication, 1999], for the comparison with models it is useful to pick larger regions that represent the range of values observed. The influence of biomass burning in this region can clearly be seen in the high mixing ratios of $\mathrm{NO}, \mathrm{NO}_{x}, \mathrm{CO}$, and NMHCs in the planetary boundary layer. The values of NO drop rapidly with altitude as it is converted to PAN and $\mathrm{HNO}_{3}$, as indicated by the in- creases in the PAN/NO $\mathrm{NO}_{x}$ and $\mathrm{HNO}_{3} / \mathrm{NO}_{x}$ ratios. The ratio $\mathrm{C}_{3} \mathrm{H}_{8} / \mathrm{C}_{2} \mathrm{H}_{6}$ is higher in the lower troposphere, also indicating fresh emissions. The levels of PAN and $\mathrm{CO}$ in the upper troposphere are comparable to those in the lower troposphere, indicating strong convection was present in this region carrying these long-lived compounds to the upper troposphere. The mixing ratios of $\mathrm{O}_{3}$ (both in situ and DIAL) are high (50-100 ppbv) throughout the troposphere, with the DIAL measurements showing a smooth increase with altitude. The profiles of NO and $\mathrm{NO}_{x}$ increase in the upper troposphere, due to lightning production and the transport of surface emissions in the convective systems, as well as having longer lifetimes in the upper troposphere [Smyth et al, 1996]. There are very high net ozone production rates near the surface, dropping to near zero in the midtroposphere, and increasing slightly in the upper troposphere where $\mathrm{NO}_{x}$ is larger and the rate of $\mathrm{O}_{3}$ loss is slower.

The profiles for the PEM-West-B "Japan_CoastEE" region, shown in Figure 3, have rather different distributions. This campaign took place during February and March, which is typically a period of strong outflow from Asia to the North Pacific [Hoell et al., 1997]. Ozone mixing ratios are quite constant throughout the troposphere (40-50 ppbv), but increase above $10 \mathrm{~km}$, or the approximate tropopause, due to stratospheric influence. High values of $\mathrm{NO}, \mathrm{NO}_{x}, \mathrm{PAN}, \mathrm{CO}$, and NMHCs are clearly seen near the surface, coming from various continental anthropogenic sources [Hoell et al., 1997]. The propane/ethane ratio $(>0.3)$ indicates that below $2 \mathrm{~km}$ the air was less than 1 day from sources (see sec-

Data-Model Comparison Regions

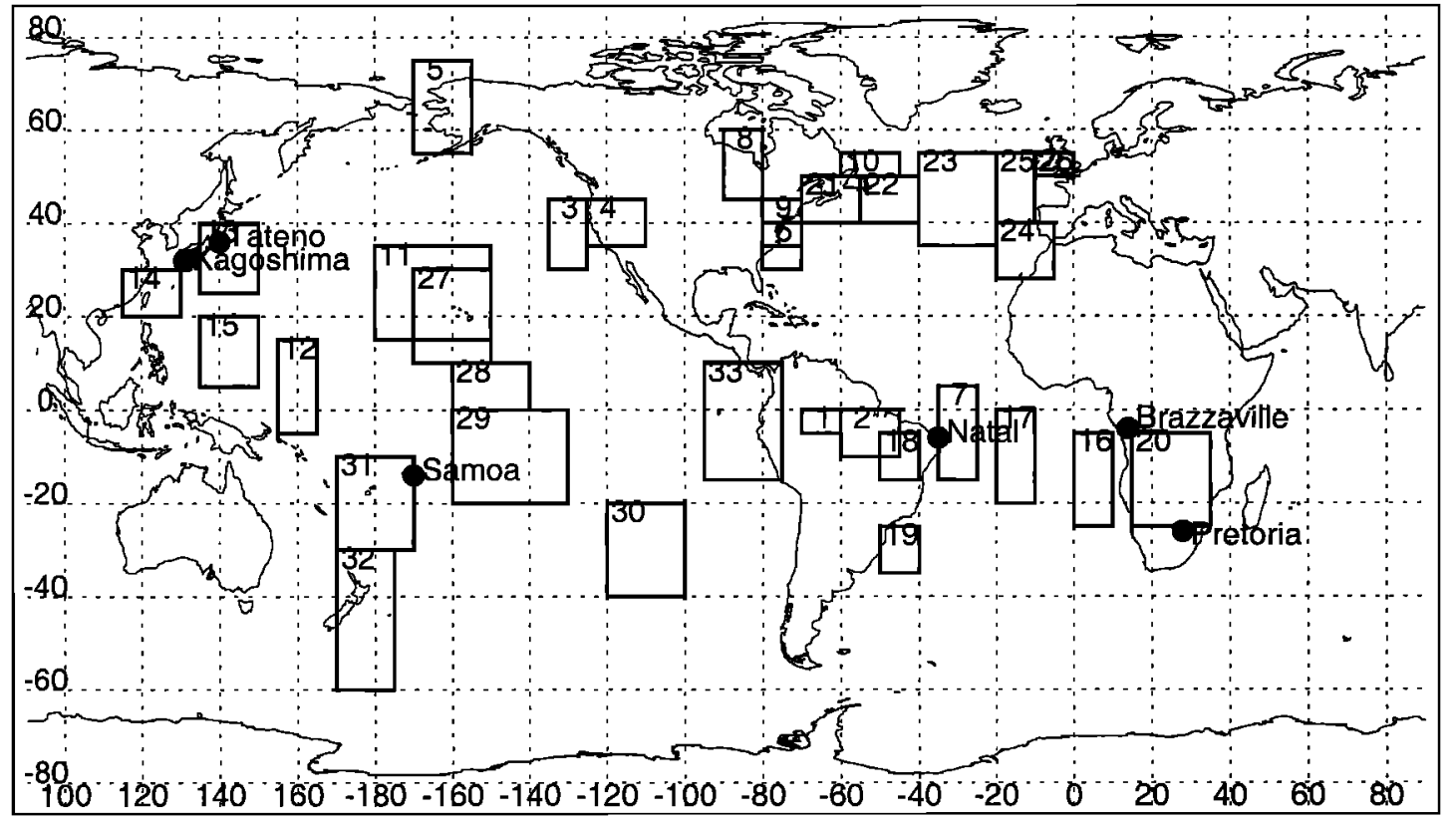

Figure 1. Map showing regions for which vertical profiles were compared. Regions are identified in Table 3. Circles show locations of ozonesondes (discussed in section 4.1). 
Table 3. Regions for Vertical Profile Data-Model Comparisons

\begin{tabular}{|c|c|c|c|c|c|c|}
\hline \multirow{2}{*}{$\begin{array}{l}\text { Campaign }^{\mathrm{a}} \\
\text { ABLE-2A }\end{array}$} & \multirow{2}{*}{$\begin{array}{c}\text { Region } \\
1\end{array}$} & \multirow{2}{*}{$\begin{array}{l}\text { Region Name } \\
\text { Brazil_W }\end{array}$} & \multicolumn{2}{|c|}{ Latitude } & \multicolumn{2}{|c|}{ Longitude } \\
\hline & & & -5 & 0 & 290 & 300 \\
\hline & 2 & Brazil_E & -10 & 0 & 300 & 315 \\
\hline \multirow[t]{2}{*}{ CITE-2 } & 3 & Pacific & 30 & 45 & 225 & 235 \\
\hline & 4 & Calif & 35 & 45 & 235 & 250 \\
\hline ABLE-2B & 2 & Brazil_E & -10 & 0 & 300 & 315 \\
\hline ABLE-3A & 5 & Alaska & 55 & 75 & 190 & 205 \\
\hline \multirow[t]{2}{*}{ CITE-3 } & 6 & Wallops & 30 & 40 & 280 & 290 \\
\hline & 7 & Natal & -15 & 5 & 325 & 335 \\
\hline \multirow[t]{3}{*}{ ABLE-3B } & 8 & Ontario & 45 & 60 & 270 & 280 \\
\hline & 9 & US_Coast_E & 35 & 45 & 280 & 290 \\
\hline & 10 & Labrador & 50 & 55 & 300 & 315 \\
\hline \multirow[t]{5}{*}{ PEM-West-A } & 11 & Pacific_N & 15 & 35 & 180 & 210 \\
\hline & 12 & Pacific_Tropics_W & -5 & 15 & 155 & 165 \\
\hline & 13 & Japan_Coast_E & 25 & 40 & 135 & 150 \\
\hline & 14 & China_Coast_E & 20 & 30 & 115 & 130 \\
\hline & 15 & Philippine_Sea & 5 & 20 & 135 & 150 \\
\hline \multirow[t]{5}{*}{ TRACE-A } & 16 & Africa_Coast_W & -25 & -5 & 0 & 10 \\
\hline & 17 & Atlantic_S & -20 & 0 & 340 & 350 \\
\hline & 18 & Brazil_E & -15 & -5 & 310 & 320 \\
\hline & 19 & Brazil_Coast_E & -35 & -25 & 310 & 320 \\
\hline & 20 & Africa_S & -25 & -5 & 15 & 35 \\
\hline \multirow[t]{6}{*}{ OCTA-2 } & 21 & NovaScotia & 40 & 50 & 290 & 305 \\
\hline & 22 & WAtlantic & 40 & 50 & 305 & 320 \\
\hline & 23 & CAtlantic & 35 & 55 & 320 & 340 \\
\hline & 24 & SEAtlantic & 28 & 40 & 340 & 355 \\
\hline & 25 & NEAtlantic & 40 & 55 & 340 & 350 \\
\hline & 26 & England & 50 & 55 & 350 & 360 \\
\hline \multirow[t]{3}{*}{ PEM-West-B } & 13 & Japan_Coast_E & 25 & 40 & 135 & 150 \\
\hline & 14 & China_Coast_E & 20 & 30 & 115 & 130 \\
\hline & 15 & Philippine_Sea & 5 & 20 & 135 & 150 \\
\hline \multirow[t]{7}{*}{ PEM-Tropics-A } & 27 & Hawaii & 10 & 30 & 190 & 210 \\
\hline & 28 & Christmas_I & 0 & 10 & 200 & 220 \\
\hline & 29 & Tahiti & -20 & 0 & 200 & 230 \\
\hline & 30 & Easter_Island & -40 & -20 & 240 & 260 \\
\hline & 31 & Fiji & -30 & -10 & 170 & 190 \\
\hline & 32 & New_Zealand & -60 & -30 & 170 & 185 \\
\hline & 33 & Guayaquil & -15 & 10 & 265 & 285 \\
\hline
\end{tabular}

acronyms are defined in the text. See Table 1 for campaign dates.

tion 2.1). The $\mathrm{PAN} / \mathrm{NO}_{x}$ and $\mathrm{HNO}_{3} / \mathrm{NO}_{x}$ ratios above $2 \mathrm{~km}$, however, are quite high, suggesting significant photochemical processing had occurred. The calculated net ozone production is an average of $1-2 \mathrm{ppbv} /$ day at $1-2 \mathrm{~km}$, moderately low due to low sun angles in winter.

Figure 4 shows the profiles from the "Tahiti" region of PEM-Tropics-A, with observations from both the P-3 and DC-8 aircraft, where available. High ozone mixing ratios (60-80 ppbv) are seen in the middle troposphere (3-6 km). $\mathrm{NO}_{x}, \mathrm{CO}, \mathrm{NMHCs}, \mathrm{PAN}$, and $\mathrm{HNO}_{3}$ are much lower than the Japan and Africa regions (Figures 2 and 3), particularly near the surface, as there are very few source emissions in the vicinity. $\mathrm{C}_{3} \mathrm{H}_{8} / \mathrm{C}_{2} \mathrm{H}_{6}$ is much less than 0.1 , indicating that the air parcels measured were highly aged. PAN is essentially zero in the warm lower troposphere, since any that is formed is rapidly thermally decomposed. $\mathrm{HNO}_{3} / \mathrm{NO}_{x}$ is roughly 5 and greater, indicative of chemically processed air. $\mathrm{H}_{2} \mathrm{O}_{2}$ is similar to the other regions, but $\mathrm{CH}_{3} \mathrm{OOH}$ is much greater, and consequently the ratio $\mathrm{H}_{2} \mathrm{O}_{2} / \mathrm{CH}_{3} \mathrm{OOH}$ is smaller (close to 1 ). Net $\mathrm{O}_{3}$ production is negative throughout the lower troposphere, and less than $1 \mathrm{ppbv} / \mathrm{d}$ above $8 \mathrm{~km}$.

These three regions provide examples of the wide variability in atmospheric composition around the globe. However, the Africa and Japan profiles show a great deal of similarity due to both regions being influenced by surface emissions despite the different sources (biomass burning versus industrial sources). For example, $\mathrm{NO}_{x}$ shows a "c"-shaped profile for both regions, due to the sources at the surface, and lightning (particularly over Africa) and aircraft emissions (more likely over places like Japan) in the upper troposphere, whereas in the Tahiti region $\mathrm{NO}_{x}$ increases monotonically with 
TRACE-A - Africa_S
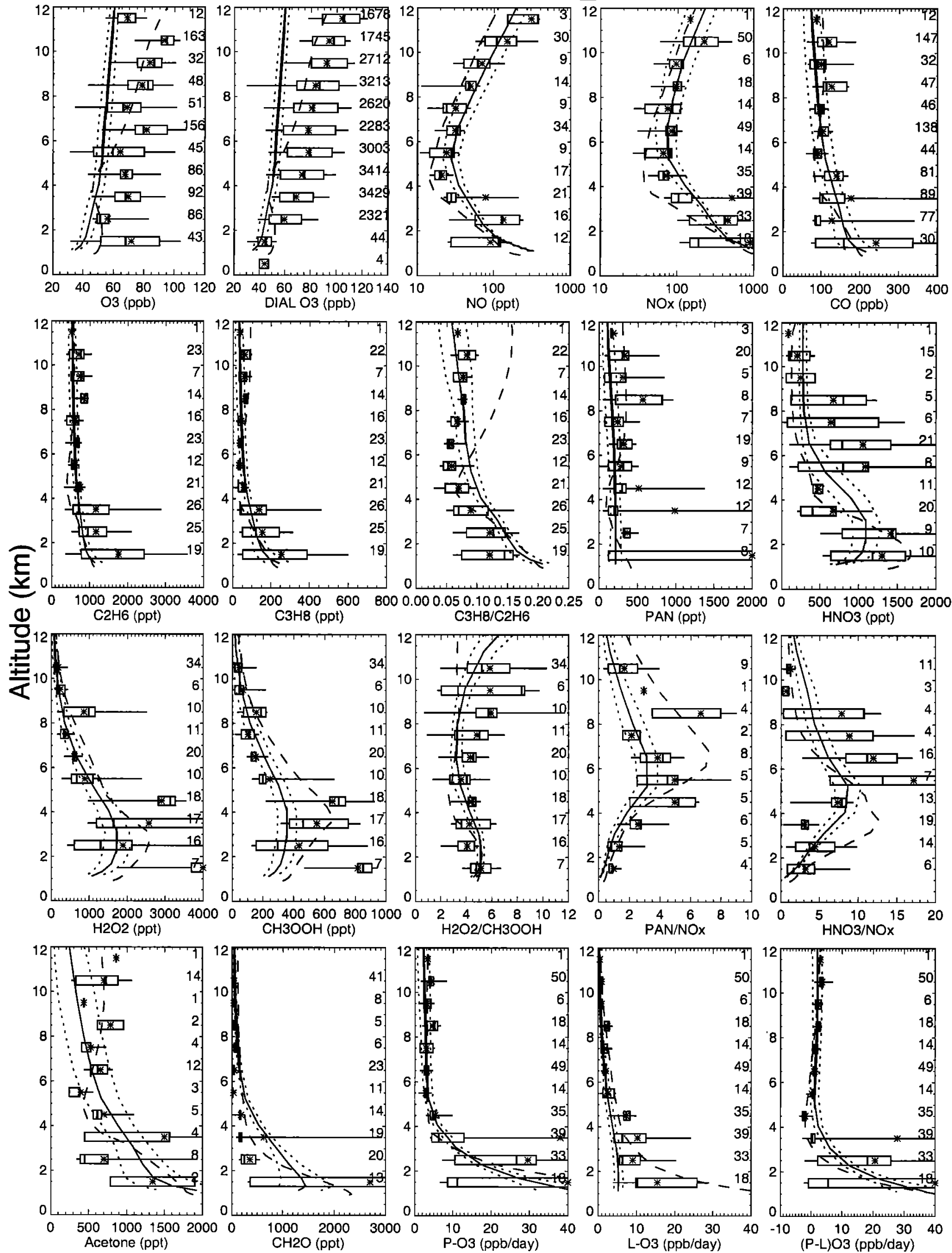

Figure 2. Vertical profiles of observations and IMAGES and MOZART model results for the "Africa_S" region from TRACE-A, plotted as a function of pressure altitude (i.e., elevation above sea level). Boxes and whiskers indicate the central $50 \%$ and $90 \%$ of the observations, with a vertical bar at the median, and a star at the mean. The number of observations at each altitude is given at the right of each panel. Box model results are shown for ozone production, loss, and net production profiles, as well as for $\mathrm{NO}_{x}$. MOZART results, mean and standard deviation in time, are shown by the solid and dotted lines. IMAGES results are the long dashed line. 
PEM-West-B - Japan_Coast_E
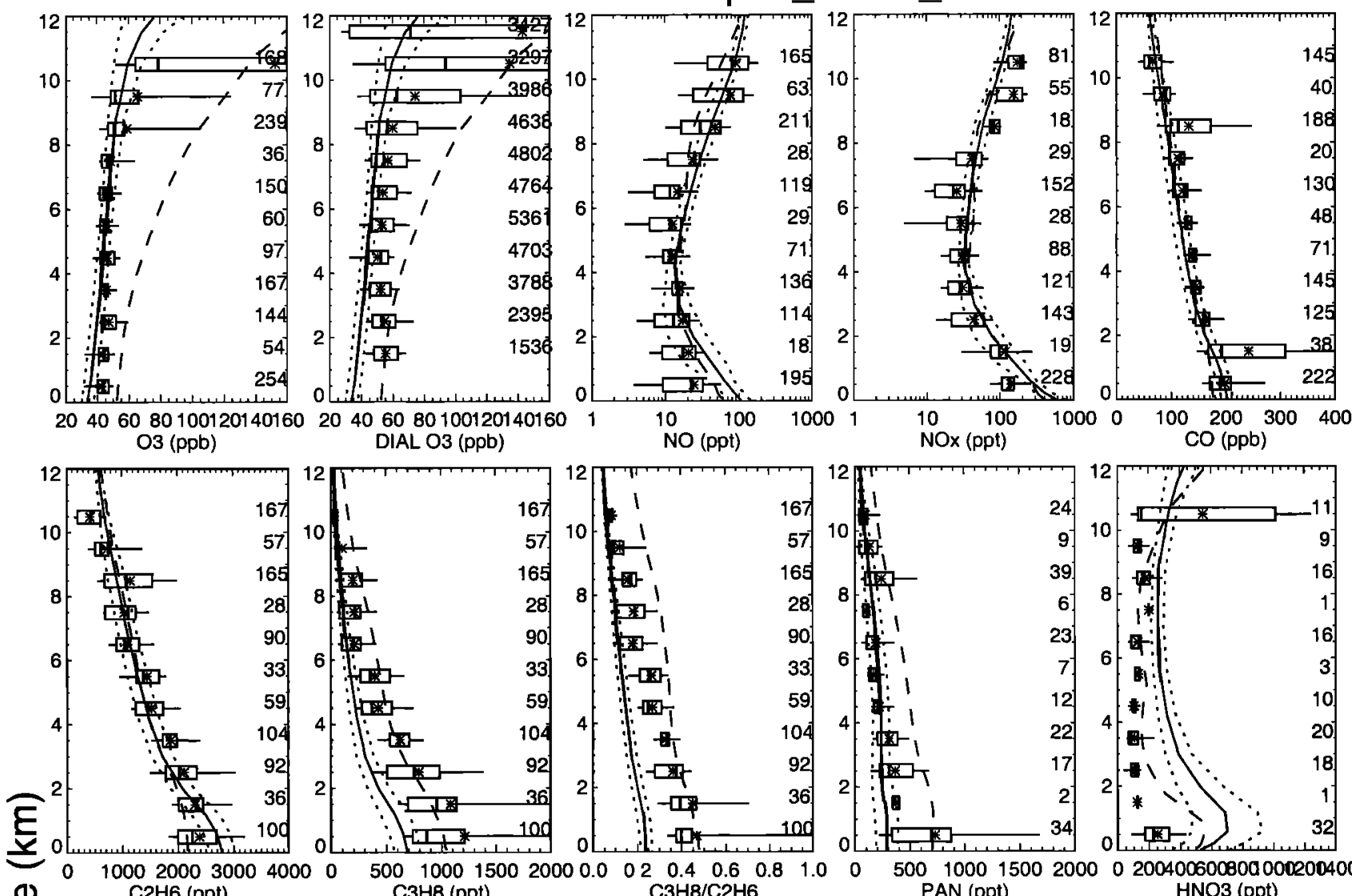

DIAL O3 (ppb)

NO (ppt)

NOx (ppt)
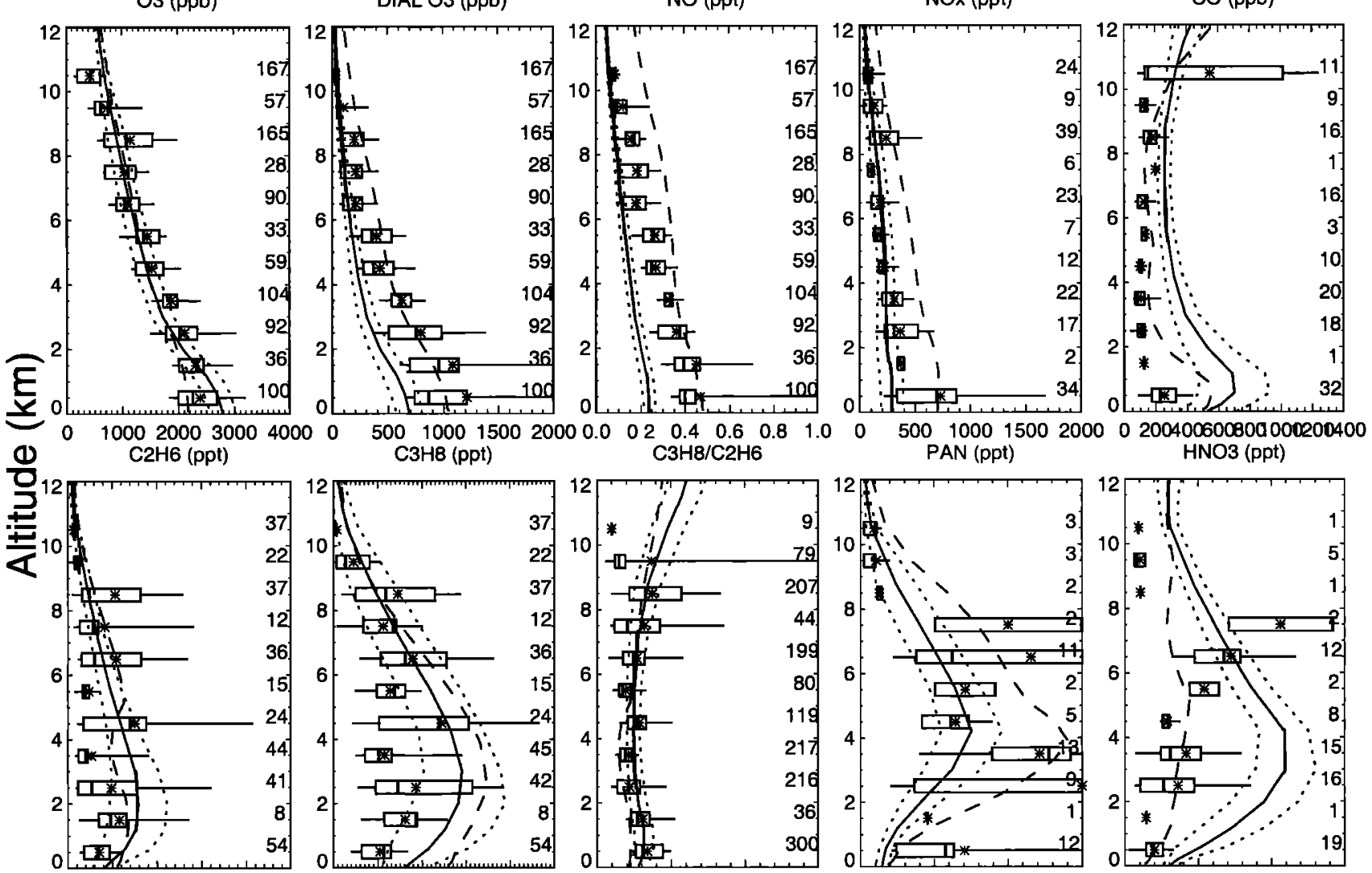
$\mathrm{C} 3 \mathrm{HB}(\mathrm{ppt})$
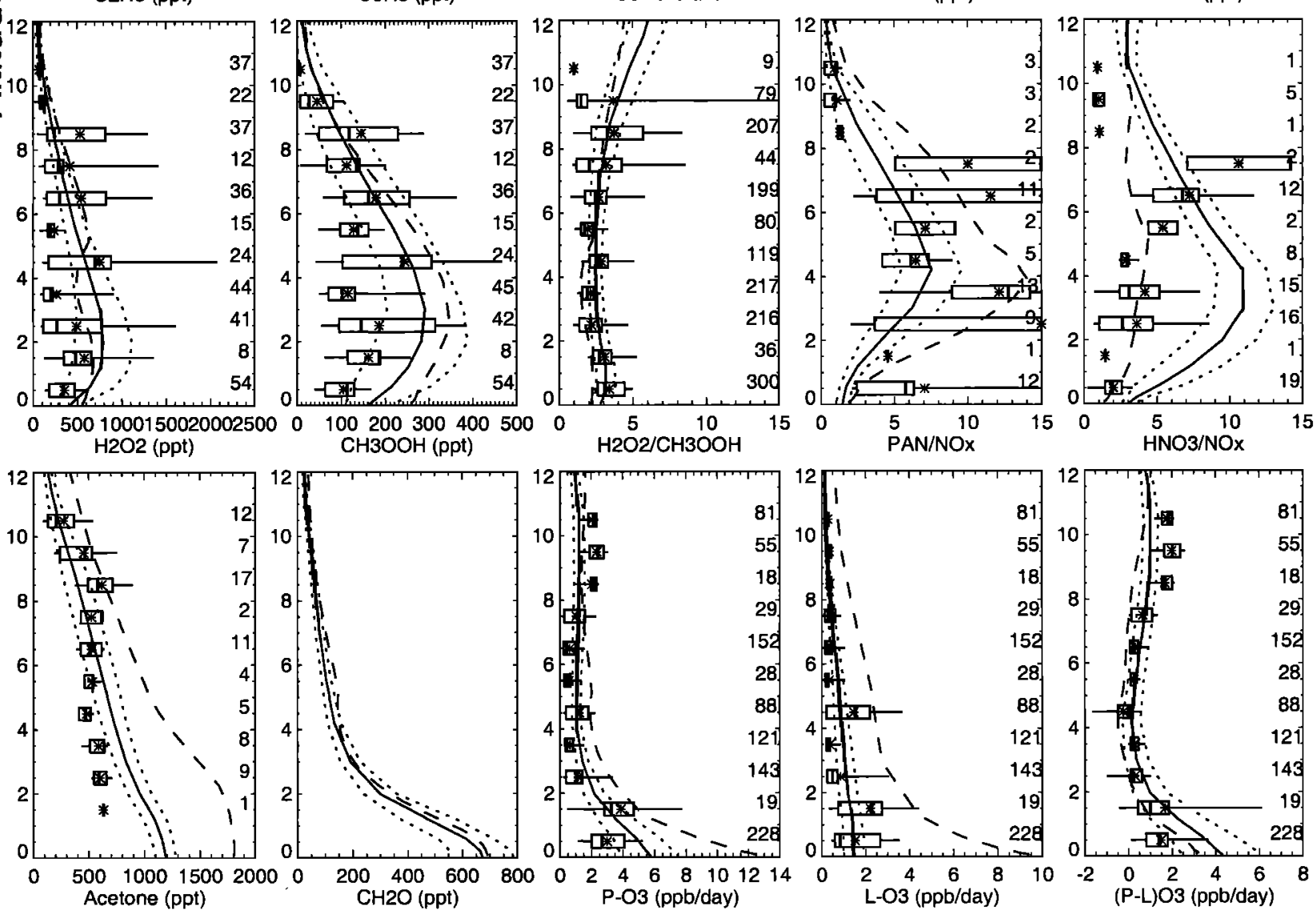

Figure 3. Vertical profiles for the "Japan_Coast_E" region of PEM-West-B, as in Figure 2. 
PEM-Tropics - Tahiti
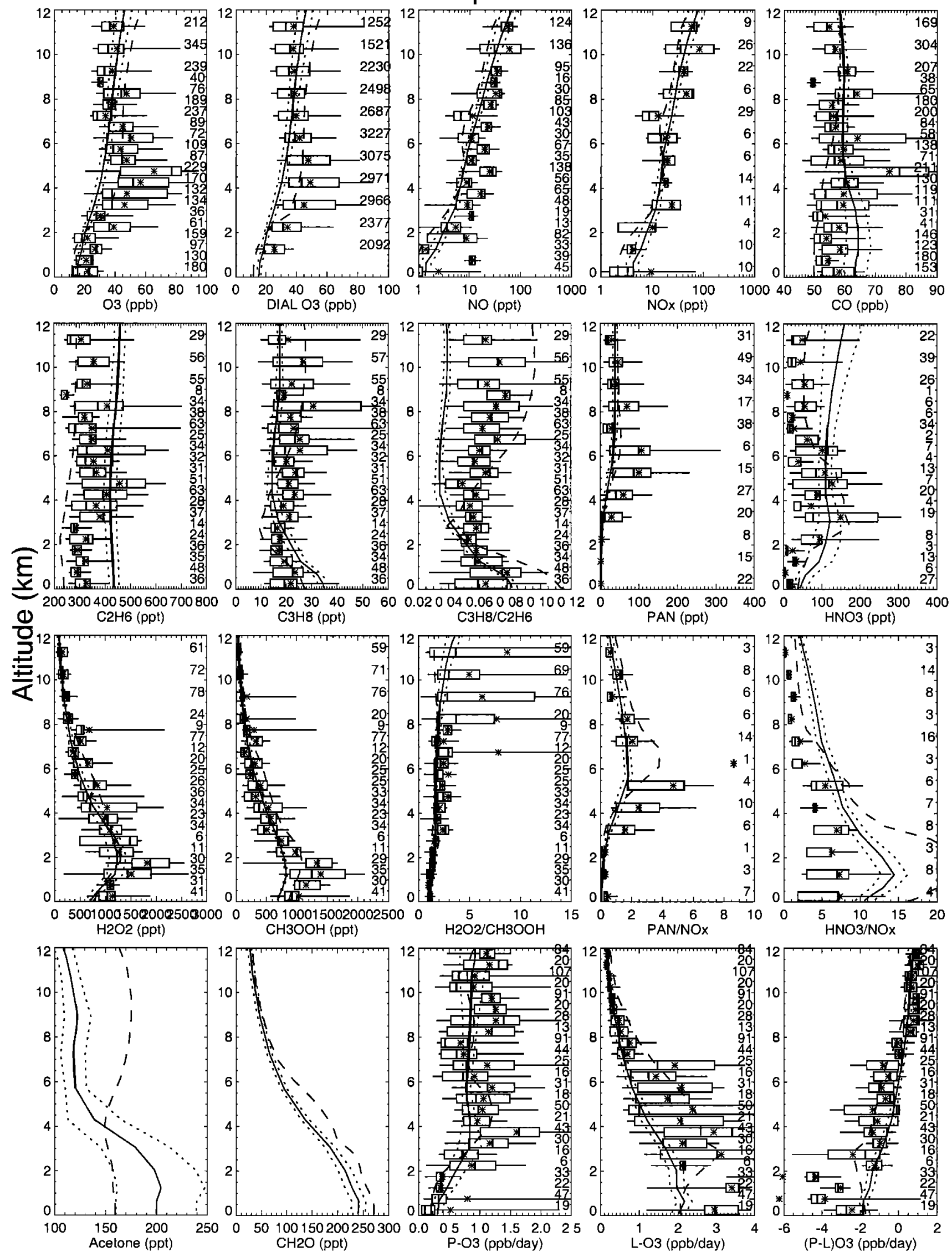

Figure 4. Vertical profiles for the "Tahiti" region of PEM-Tropics, as in Figure 2. Observations taken from the DC-8 are shown in the bottom half of each kilometer and the P-3 in the top half. The $\mathrm{O}_{3}$ production and loss rates from M. Schultz on the bottom and from J. Crawford on top of each kilometer in the last three panels. 
altitude from very low values at the surface. $\mathrm{CO}$ and NMHCs are also high near the surface, and decrease with altitude in Africa and Japan contrasting with low values in Tahiti. Net $\mathrm{O}_{3}$ production, $(\mathrm{P}-\mathrm{L})$ is quite large in the lower troposphere due to surface sources (10-30 ppbv/d over Africa), whereas over Tahiti there is net destruction $(-2$ to $-5 \mathrm{ppbv} / \mathrm{d})$.

\section{Comparison of Data Composites to Other Climatologies}

The data composites presented can be compared with other data sets and models, and several examples are shown in this section. Since the aircraft measurements are essentially "snapshots" and there is seldom more than one campaign at any given location and season, it is valuable to compare the composites with true climatologies where possible, as a check of the representativeness of the composites. One suitable climatology is that developed from ozonesondes by Logan [1999]. The measurements of $\mathrm{O}_{3}$ and $\mathrm{NO}_{x}$ made from commercial aircraft in the MOZAIC and NOXAR projects also approach climatologies, and these results are compared with the composites.

\subsection{Ozonesondes}

The aircraft measurements are compared to the ozonesonde climatologies presented by Logan [1999] in Figure 5. Although there are only a few locations where the ozonesondes are in proximity to the aircraft regions (see Figure 1), this comparison can help identify instances where the aircraft observations differ from long-term averages. The ozonesonde climatology is available as monthly averages and standard deviations at a standard set of pressure levels for about 35 sites. Sonde data from the month of the campaigns have been used. Also shown with the region data are the median values from the $5^{\circ} \times 5^{\circ}$ grids for the nine grid cells surrounding the ozonesonde site.

The aircraft data from the "Fiji" region of PEMTropics-A (Figure 5a) are significantly higher (20-40 ppbv) than the ozonesonde climatology for Samoa $\left(14^{\circ} \mathrm{S}\right.$, $170^{\circ} \mathrm{W}$ ) in September, particularly in the middle troposphere, implying that those observations do not represent average conditions. The meteorological analysis indicated climatological airflow during the campaign (see section 2.1), and the ozonesondes at Samoa during PEM-Tropics-A agreed with previous years [Hoell et al., 1999; J. Logan, personal communication, 1999]. The flights during PEM-Tropics- $\mathrm{A}$ in that region encountered rapid transport from Africa (particularly south of Fiji) and had been strongly influenced by biomass burning [Fuelberg et al., 1999], thus increasing the average values observed in that region. Samoa is in the northeast corner of that region and the relatively small standard deviation in the sonde profiles (Figure 5a) indicates it is infrequently influenced by biomass burning.
The observations obtained during two different campaigns in eastern Brazil, the "Natal" region from CITE3 and "Brazil E" from TRACE-A are compared to the ozonesonde data from Natal $\left(6^{\circ} \mathrm{S}, 35^{\circ} \mathrm{W}\right)$ in September (Figures $5 \mathrm{~b}$ and $5 \mathrm{c}$ ). The CITE-3 measurements are generally higher than the sondes, but the TRACEA agreement is good. Comparison of the TRACE-A "Africa_S" region to sonde climatologies for Brazzaville $\left(4^{\circ} \mathrm{S}, 14^{\circ} \mathrm{E}\right)$ and Pretoria $\left(26^{\circ} \mathrm{S}, 28^{\circ} \mathrm{E}\right)$ during September (Figures $5 \mathrm{~d}$ and $5 \mathrm{e}$ ) shows much greater variability in the aircraft data than indicated by the sondes, though on average there is agreement between the two. The sonde profile at Pretoria is slightly lower than at Brazzaville, probably indicating fewer fires in the southern area. A greater number of aircraft observations were made near Pretoria (as indicated by the circles).

In Figures $5 \mathrm{f}$ and $5 \mathrm{~g}$, the "Japan_Coast_E" region sampled during PEM-West-A is shown with the ozonesonde climatologies of Kagoshima $\left(32^{\circ} \mathrm{N}, 131^{\circ} \mathrm{E}\right)$ and Tateno $\left(36^{\circ} \mathrm{N}, 140^{\circ} \mathrm{E}\right)$ for September. There is large variability in the aircraft data during this period; however, the aircraft data are generally lower than both sets of sondes throughout the troposphere. The same region is compared for PEM-West-B (Figures $5 \mathrm{~h}$ and $5 \mathrm{i})$, and the sonde data from February for the same two stations are used. Above $8 \mathrm{~km}$ there is large variability in the aircraft data due to sampling both stratospheric and tropospheric air, but the aircraft data is significantly lower than the sondes at these altitudes. Below $6 \mathrm{~km}$ there is much less scatter in the aircraft data during February (PEM-West-B) than September (PEM-West-A) and the agreement overall between aircraft and sonde data is good, except at Kagoshima near the surface.

The instances of large differences between the sonde and aircraft data (e.g., Fiji) imply that those regions of aircraft data may not be appropriate for evaluation of models using climatological meteorology. The aircraft data generally have much higher variability than seen in the sonde climatology. These factors indicate that aircraft data can be used more effectively in the evaluation of models using assimilated winds for the time of the observations.

\subsection{Measurements Obtained on Commercial Aircraft}

Measurements using research-quality instrumentation on commercial aircraft provide a large amount of data along flight corridors in the upper troposphere, as well as profiles on takeoff and landing, and can therefore provide true seasonal averages in these regions. Results from two programs, Nitrogen Oxides and Ozone Measurements Along Air Routes (NOXAR) and Measurement of Ozone and Water Vapor by Airbus In-Service Aircraft (MOZAIC), are presented here. Several other similar programs exist (e.g., CARIBIC [Brenninkmeijer et al., 1999]; Japan Air Lines [Matsueda et al., 1998]). 
a) Samoa/PMT-Fiji

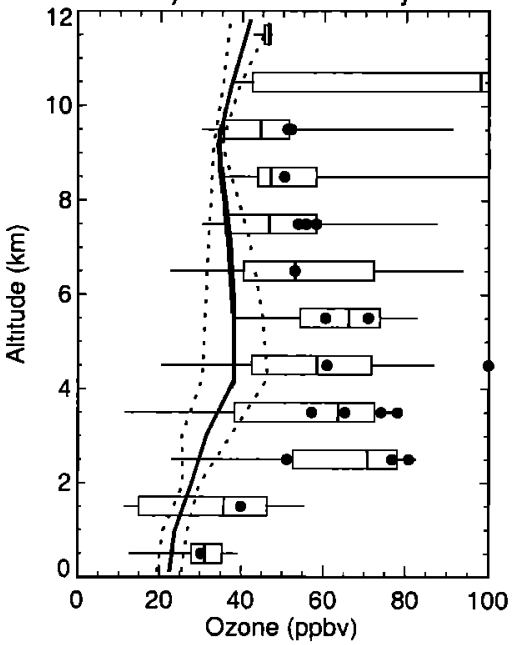

d) Brazzaville/TRA-Africa_S

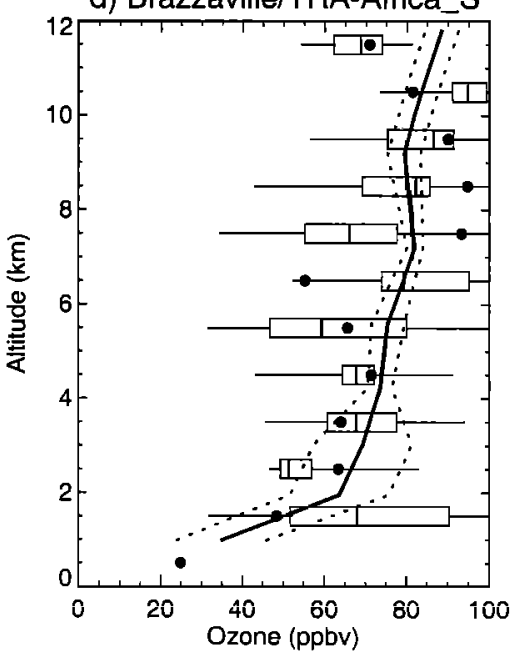

g) Tateno/PWA-Japan

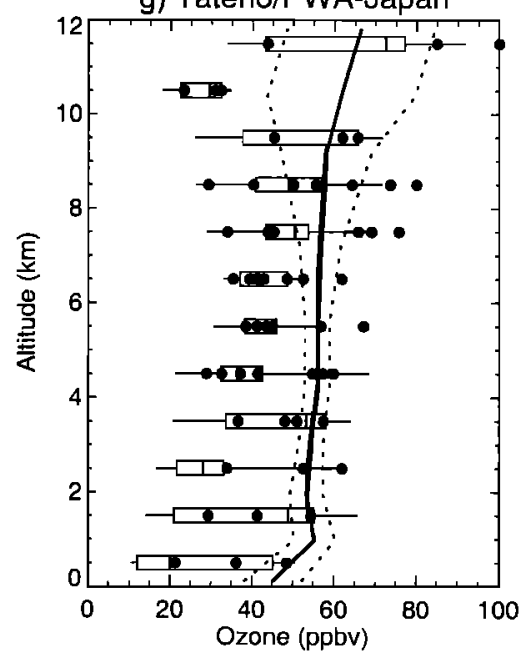

b) Natal/CT3-Natal

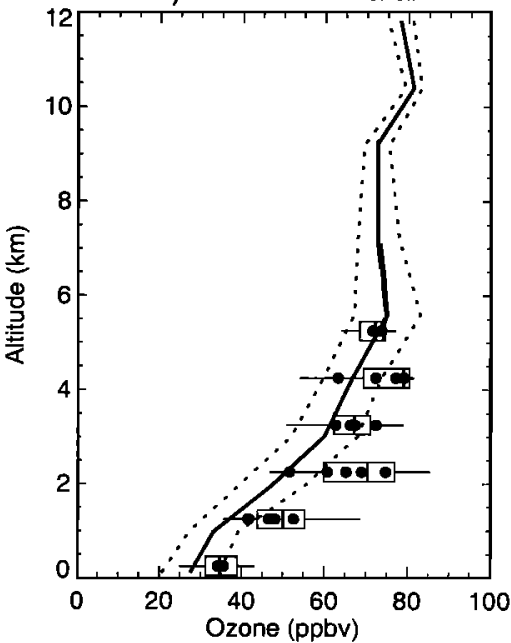

e) Pretoria/TRA-Africa_S

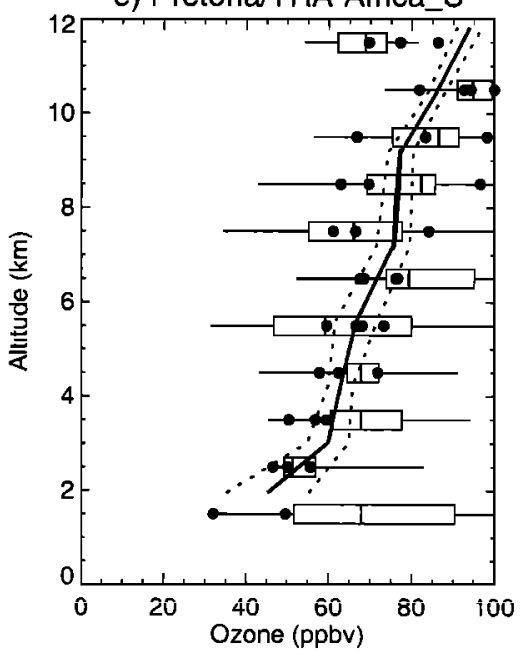

h) Kagoshima/PWB-Japan

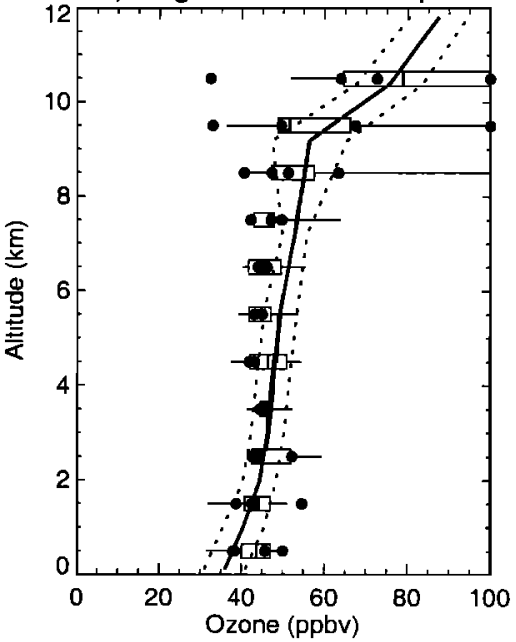

c) Natal/TRA-Brazil E

20,519
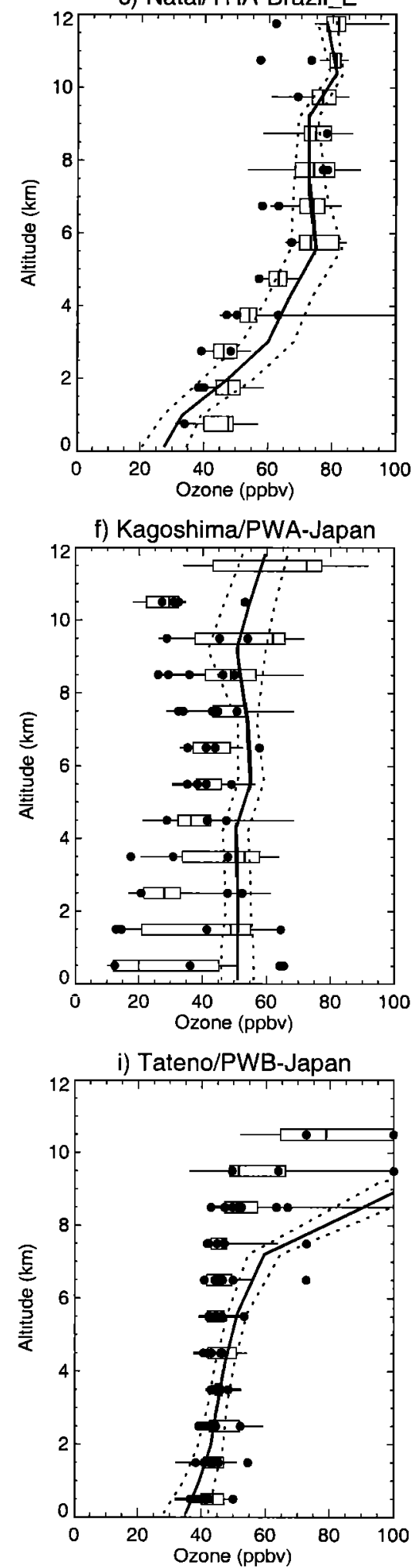

Figure 5. Comparison of profiles and data composites of airborne measurements with ozonesonde climatologies [Logan, 1999]. The means and standard deviations of the sonde data for 1 month are shown by solid and dotted lines, respectively. Aircraft data from the $5^{\circ} \times 5^{\circ}$ climatology within $5^{\circ}$ of the sonde location are shown by circles. Box and whisker plots indicate the range of observations within the specified region, and the median is indicated by a vertical bar (see Figure 1 and Table 3). (a) Samoa sondes (September) versus PMT-Fiji region. (b) Natal sondes (September) versus CT3-Natal regions. (c) Natal sondes (September) versus TRA-Brazil_E regions. (d) Brazzaville sondes (September) versus TRA-Africa_S region. (e) Pretoria sondes (September) versus TRA-Africa_S region. (f) Kagoshima sondes (September) versus PWA-Japan region. (g) Tateno sondes (September) versus PWA-Japan region. (h) Kagoshima sondes (February) versus PWB-Japan region. (i) Tateno sondes (February) versus PWB-Japan region. 
NOXAR sampled $\mathrm{NO}, \mathrm{NO}_{x}$, and $\mathrm{O}_{3}$ from a Swissair Boeing 747 between May 1995 and May 1996 [Brunner et al., 1998; Dias-Lalcaca et al., 1998]. The flights followed three main routes from Zurich, one across the North Atlantic to the eastern United States, and northern and southern routes to east Asia. It should be noted that since these measurements are made along the flight corridors at fixed flight levels some bias in the measurements is introduced, since the measurements are affected more than average by aircraft emissions. When aircraft plumes were excluded from the data (a few thousand of them, with ages of minutes to 10 hours) the average $\mathrm{NO}_{x}$ concentration over mid-latitudes is lowered by 26 pptv, which is $20 \%$ of the annual average (D. Brunner, personal communication, 1999). All of the data, including the plumes, have been binned onto the same grid as the data composites, with averages made over each season. The median value of each grid box is used here, thus reducing the influence of the plumes on the composites.

The MOZAIC program installed ozone analyzers and water vapor sensors on five Airbus A340 passenger aircraft [Marenco et al., 1998], and measurements have been made since 1994. Ozone climatologies developed from the first phase of MOZAIC, September 1994- August 1996, are included here [Thouret et al., 1998]. The largest number of flights are across the North Atlantic, but data were also collected on flight tracks between Europe and western United States, South America, southern Africa, southeast Asia, and Japan. The MOZAIC data were provided for $2.5^{\circ} \times 2.5^{\circ}$ grid cells for flight level 350 in seasonal averages, which have then been averaged into the $5^{\circ} \times 5^{\circ}$ grid of the data composites.

Observations of $\mathrm{O}_{3}$ and $\mathrm{NO}$ at $10-11 \mathrm{~km}$ from all of the research campaigns that are included in the data composites (listed in Table 2), along with NOXAR and MOZAIC, are shown in Plate 5. The commercial aircraft observations at the standard aircraft flight level 350 (approximately $35 \mathrm{kft}$, or $10.6 \mathrm{~km}$ ), which is the altitude where most of the MOZAIC and NOXAR data have been collected, are shown here.

At this altitude most of the data north of about $45^{\circ} \mathrm{N}$ appears to have been obtained in the stratosphere, as evident from the $\mathrm{O}_{3}$ mixing ratios greater than $100 \mathrm{ppbv}$. In previous studies of these data, stratospheric and tropospheric air have been separated, using criteria based on the ozone or water vapor mixing ratios, or on potential vorticity analyses [Thouret et al., 1998; Brunner et al., 1998]. However, for this comparison with the data composites we are using the complete data sets. A comparison of the ozone measurments from NOXAR and MOZAIC for the same flight level and within $30 \mathrm{~min}$ of each other showed excellent agreement [Dıas-Lalcaca et al., 1998].

Primarily the NOXAR and MOZAIC data sets significantly complement the research aircraft measurements in providing data where none was available previously. There are a few places, however, where comparisons can be made between the data composites and commercial aircraft data sets. Examples of several of these comparisions are shown in Figures 6 and 7, with the regions indicated on Plate 5. The comparison of ozone measurements is made in Figure 6, and includes the in situ and DIAL measurements from the research campaigns and the NOXAR and MOZAIC data. Overall, the measurements show general agreement. In the regions across the North Atlantic (Figures 6a-6c) both MOZAIC and NOXAR data are available. In DJF over the western North Atlantic (Figure 6a) the average of the composite data is $100-200$ ppbv higher than NOXAR and MOZAIC, but the ranges all overlap. In JJA, composite in situ data are 50-100 ppbv lower than the NOXAR and MOZAIC data, but the range of DIAL data exceeds that of the commercial air measurements. Over the eastern Atlantic in JJA (Figure 6c), the narrow range of composite data is lower than the lowest values observed by MOZAIC or NOXAR. There are far fewer NOXAR and MOZAIC data in the remaining regions over South America (Figures 6d-6f) and eastern Asia (Figures 6g-6h), however, the agreement with the composite and DIAL data is quite good.

There are only three regions where the NO data from NOXAR overlaps with the data composites (Figure 7), and it is difficult to conclude much from the comparison. Over the western Atlantic during DJF (Figure 7a), NOXAR observations average $60 \mathrm{pptv}$, whereas the composite data average $100 \mathrm{pptv}$, and range from below 10 pptv to 700 pptv. In JJA (Figure 7b) the averages agree well, but the composites include low values not seen in NOXAR. Over the eastern Atlantic in JJA (Figure 7c), the composite data average is about twice that of the NOXAR data. The high variability of the NO distributions makes it difficult to determine if there is much significance in these discrepancies.

\section{Model Evaluation}

Results from two models are compared with the observations as examples of uses of the data composites. Model for Ozone and Related Chemical Tracers (MOZART-1) and Intermediate Model of Global Evolution of Species (IMAGES) are both three-dimensional global chemical transport models (CTMs) for the troposphere. They have similar chemical schemes and calculate the distribution of more than 50 species, including $\mathrm{O}_{3}, \mathrm{HO}_{x}, \mathrm{NO}_{x}$, methane, nonmethane hydrocarbons (NMHC) (ethane, propane, ethylene, propylene, isoprene, $\alpha$-pinene, and n-butane as a surrogate for the other higher hydrocarbons), and their degradation products. The two models differ in their advection, convection and diffusion schemes, meteorology, emissions, and spatial and temporal resolutions. The global emissions used in the models are summarized in Table 4. The following two sections briefly describe the models, and sections 5.3-5.5 present examples of how the data composites can be used to evaluate model results. 
a)
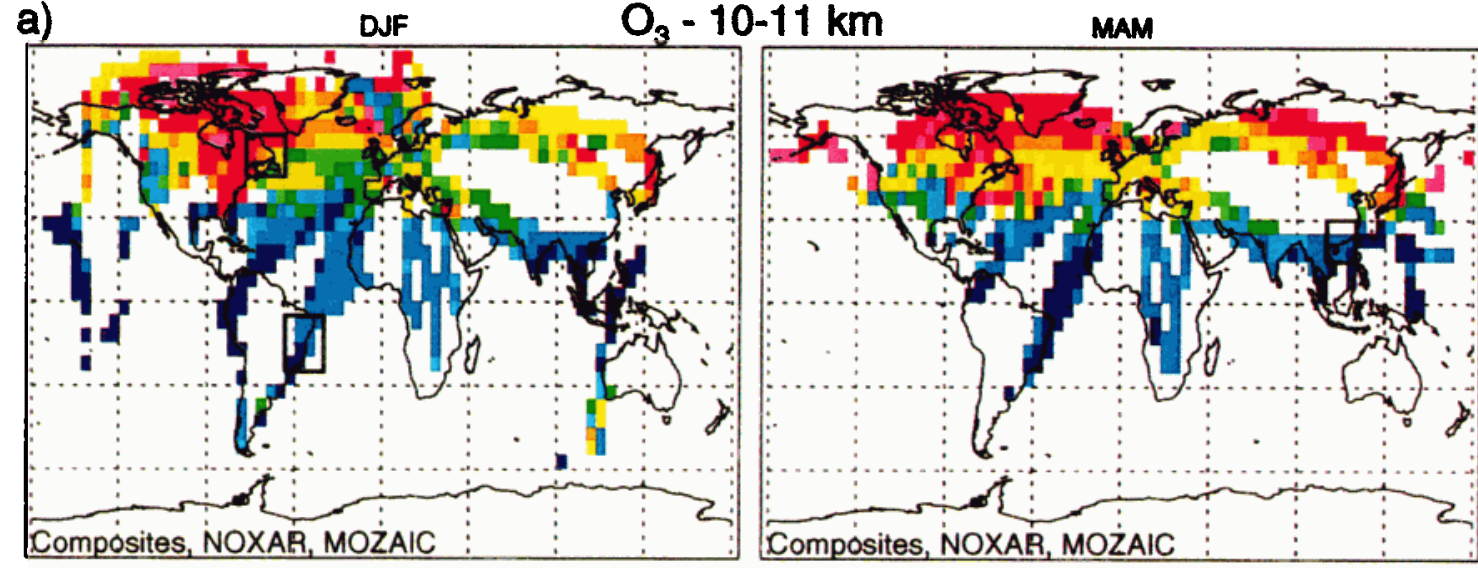

ppbv
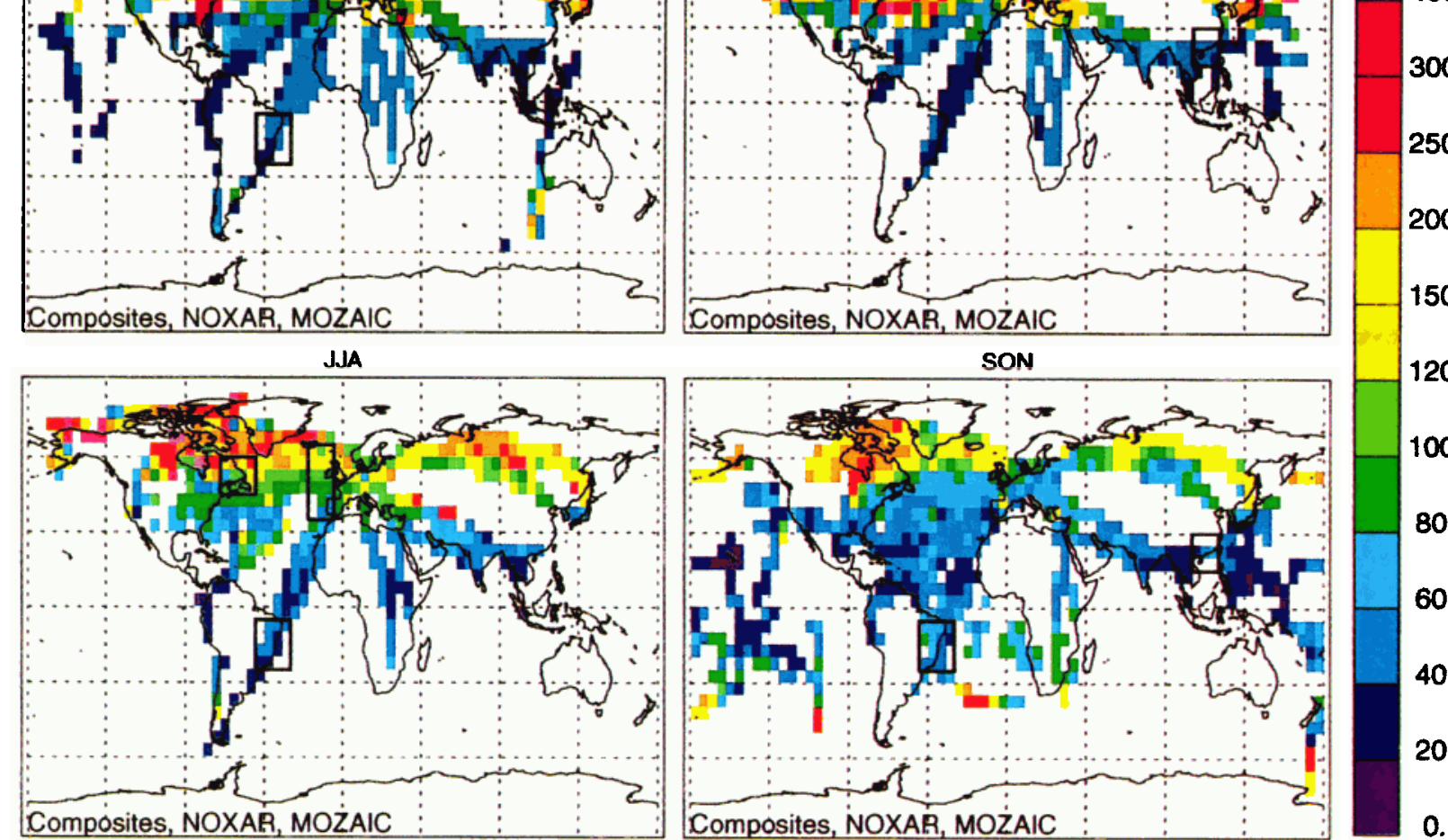

b)

D.F

NO - 10-11 km

MAM
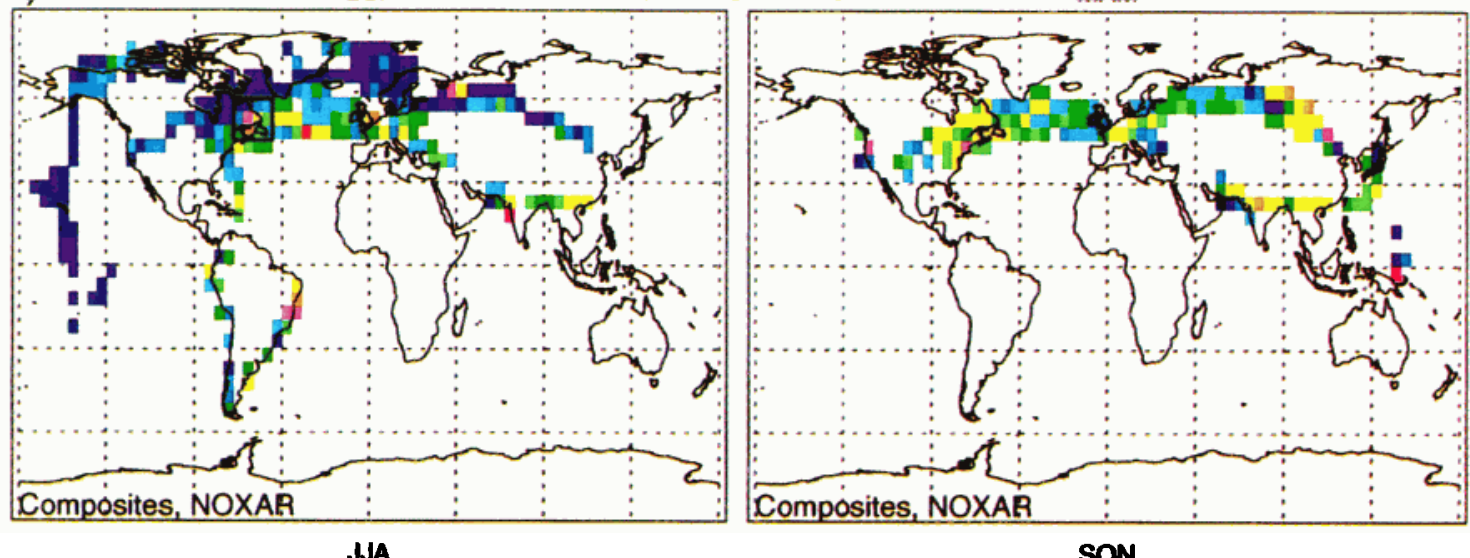

pptv

250.

200.

175.

150.

125.
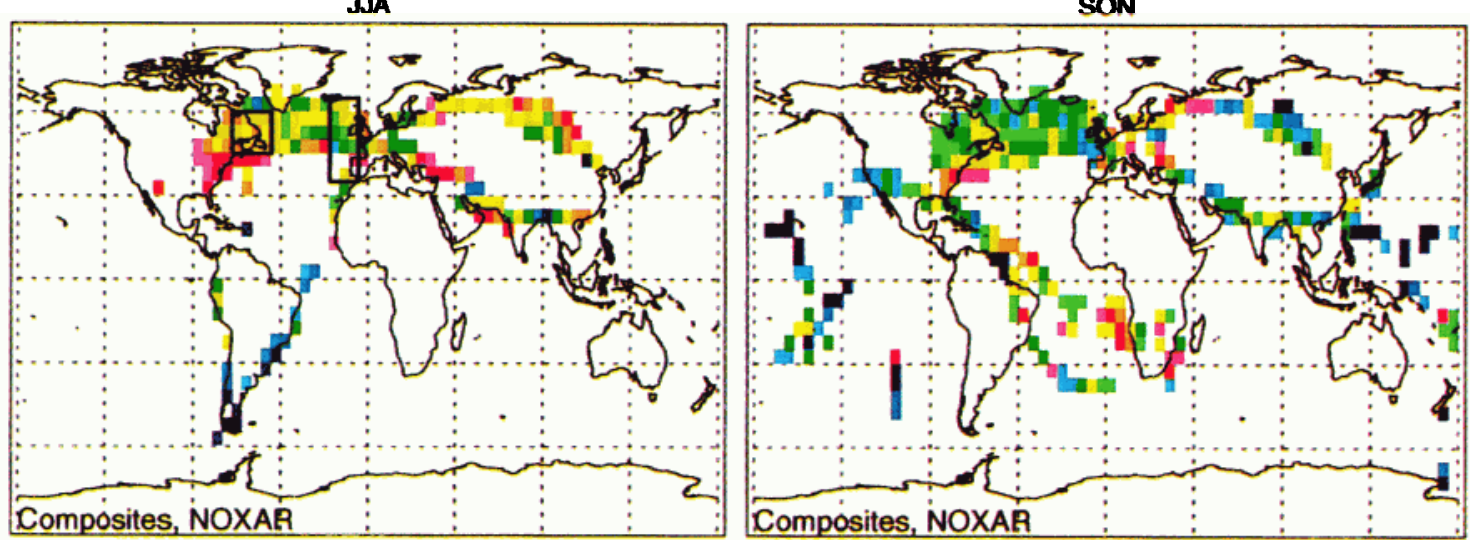

100.

80.

60.

40.

20.

10.

0.

Plate 5. (a) Data composites of $\mathrm{O}_{3}$ for $10-11 \mathrm{~km}$ (i.e., all data in Table 2 available at this altitude) with the NOXAR and MOZAIC data. (b) Data composites of NO $\left(\mathrm{SZA}<90^{\circ}\right.$ ) for $10-11 \mathrm{~km}$ with NOXAR observations. Boxes indicate regions of comparison between composites, NOXAR, and MOZAIC. 

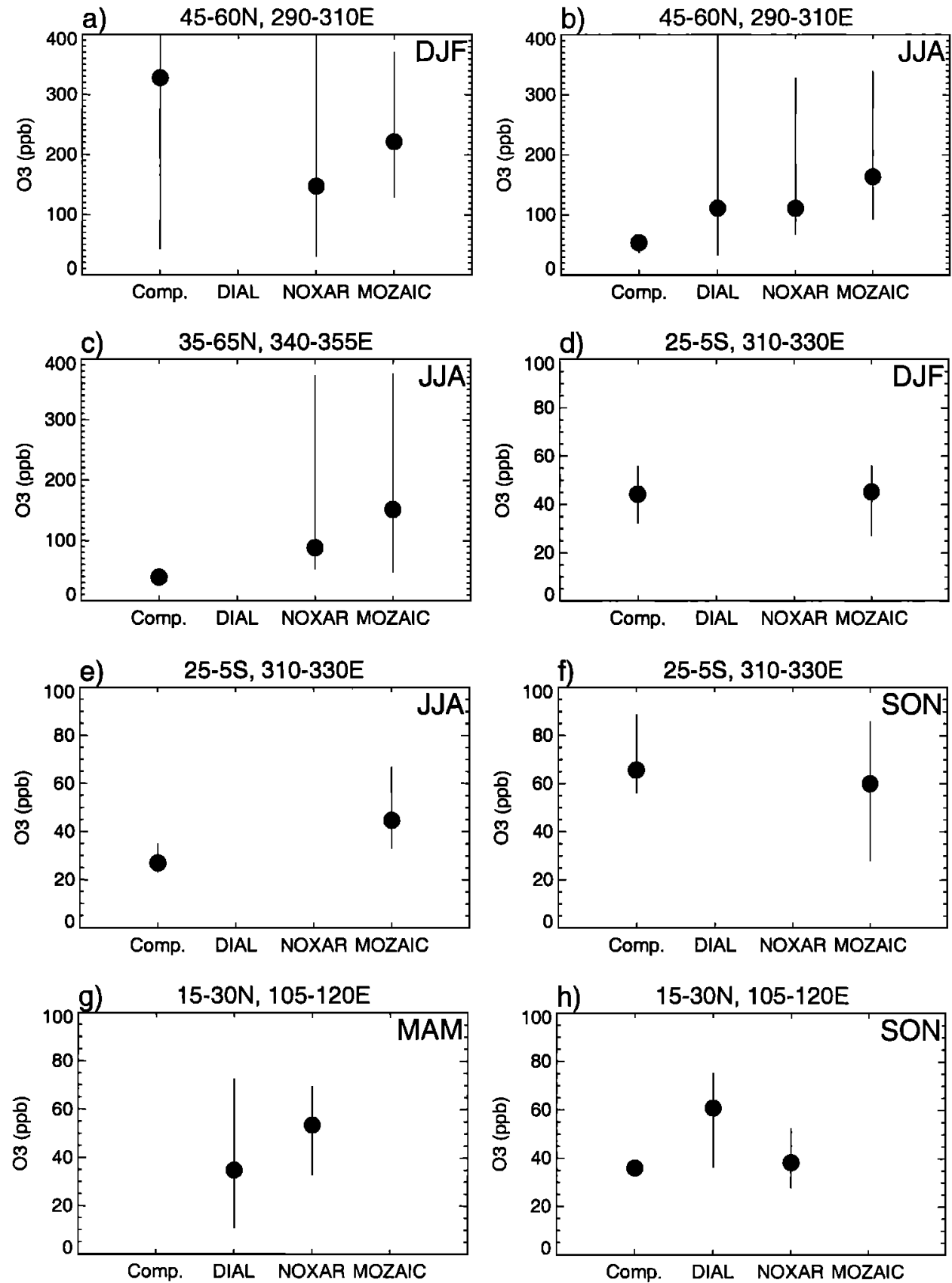

Figure 6. Comparisons of in situ and DIAL $\mathrm{O}_{3}$ data from the data composites with NOXAR and MOZAIC observations for regions shown in Plate 5. Plots were created using the $5^{\circ} \times 5^{\circ}$ gridded data of the composites within each region: circles indicate the weighted average of the medians, and lines show the range of the quartiles.

a) $45-60 \mathrm{~N}, 290-310 \mathrm{E}$

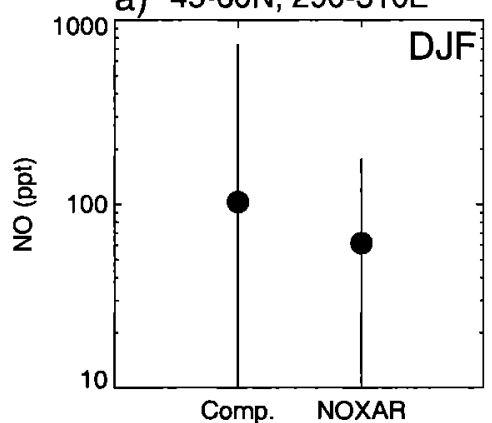

b) $45-60 \mathrm{~N}, 290-310 \mathrm{E}$

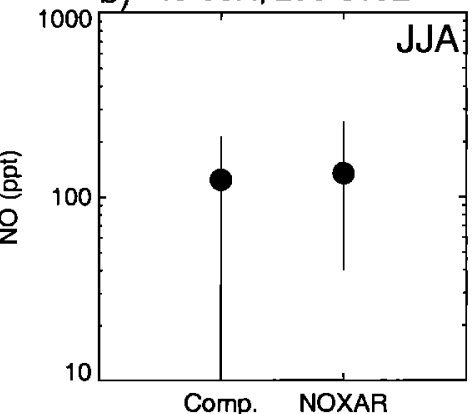

c) $35-65 \mathrm{~N}, 340-355 \mathrm{E}$

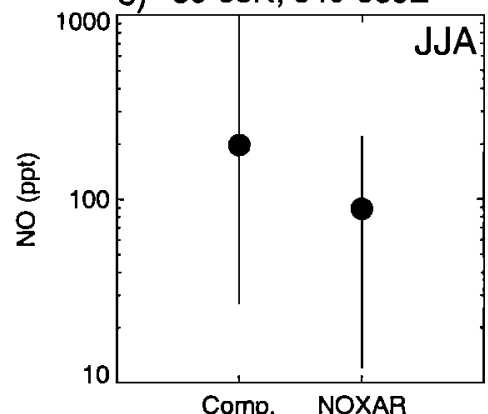

Figure 7. Comparison of NO from composites with NOXAR observations, as in Figure 6. 
Table 4. Global Emissions Used in MOZART and IMAGES

\begin{tabular}{|c|c|c|c|}
\hline Species, Units & Source & MOZART $^{B}$ & IMAGES $^{\mathrm{b}}$ \\
\hline $\mathrm{NO}_{x}, \mathrm{Tg} \mathrm{N} / \mathrm{yr}$ & $\begin{array}{l}\text { industrial } \\
\text { biomass buring } \\
\text { biogenic } \\
\text { aircraft } \\
\text { lightning }\end{array}$ & $\begin{array}{c}21.4 \\
7.5 \\
6.6 \\
0.51 \\
7\end{array}$ & $\begin{array}{c}21.0 \\
7.8 \\
5.5 \\
0.44 \\
3\end{array}$ \\
\hline $\mathrm{CO}, \mathrm{Tg} / \mathrm{yr}_{\mathrm{r}}$ & $\begin{array}{l}\text { industrial } \\
\text { biomass burning } \\
\text { biogenic } \\
\text { ocean }\end{array}$ & $\begin{array}{c}382 \\
662 \\
162 \\
13\end{array}$ & $\begin{array}{c}382 \\
626 \\
162 \\
20\end{array}$ \\
\hline $\mathrm{CH}_{2} \mathrm{O}, \mathrm{Tg} / \mathrm{yr}$ & industrial & 2.3 & 2.3 \\
\hline Acetone, $\mathrm{Tg} / \mathrm{yr}$ & $\begin{array}{l}\text { industrial } \\
\text { biomass burning } \\
\text { biogenic }\end{array}$ & $\begin{array}{l}1.5 \\
14 \\
18\end{array}$ & $\begin{array}{c}1 \\
16 \\
23\end{array}$ \\
\hline $\mathrm{C}_{2} \mathrm{H}_{6}, \mathrm{Tg} \mathrm{C} / \mathrm{yr}$ & $\begin{array}{l}\text { industrial } \\
\text { biomass burning } \\
\text { blogenic } \\
\text { ocean }\end{array}$ & $\begin{array}{l}6.0 \\
4.4 \\
0.8 \\
0.8\end{array}$ & $\begin{array}{l}6.0 \\
4.7 \\
0.8 \\
0.8\end{array}$ \\
\hline $\mathrm{C}_{3} \mathrm{H}_{8}, \mathrm{Tg} \mathrm{C} / \mathrm{yr}$ & $\begin{array}{l}\text { industrial } \\
\text { biomass burning } \\
\text { biogenic } \\
\text { ocean }\end{array}$ & $\begin{array}{l}3.8 \\
2.3 \\
1.6 \\
1.4\end{array}$ & $\begin{array}{l}9.8 \\
1.9 \\
1.6 \\
1.4\end{array}$ \\
\hline $\mathrm{C}_{2} \mathrm{H}_{4}, \mathrm{Tg} \mathrm{C} / \mathrm{yr}$ & $\begin{array}{l}\text { industrial } \\
\text { biomass burning } \\
\text { biogenic } \\
\text { ocean }\end{array}$ & $\begin{array}{c}4.3 \\
13.6 \\
4.3 \\
8.2\end{array}$ & $\begin{array}{c}4.3 \\
14.7 \\
4.3 \\
8.2\end{array}$ \\
\hline $\mathrm{C}_{3} \mathrm{H}_{6}, \mathrm{Tg} \mathrm{C} / \mathrm{yr}$ & $\begin{array}{l}\text { industrial } \\
\text { biomass burning } \\
\text { biogenic } \\
\text { ocean }\end{array}$ & $\begin{array}{l}1.7 \\
6.0 \\
0.8 \\
9.9\end{array}$ & $\begin{array}{l}1.7 \\
6.5 \\
0.8 \\
9.9\end{array}$ \\
\hline $\mathrm{C}_{4} \mathrm{H}_{10}, \mathrm{Tg} \mathrm{C} / \mathrm{yr}$ & $\begin{array}{l}\text { industrial' } \\
\text { biomass burning } \\
\text { biogenic } \\
\text { ocean }\end{array}$ & $\begin{array}{l}63.7 \\
11.3 \\
73.2 \\
58.2\end{array}$ & $\begin{array}{c}63.7 \\
10.3 \\
0 \\
58.2\end{array}$ \\
\hline Isoprene, $\mathrm{Tg} \mathrm{C} / \mathrm{yr}$ & biogenic & 220 & 568 \\
\hline Terpenes, $\mathrm{Tg} \mathrm{C} / \mathrm{yr}$ & biogenic & 130 & 144 \\
\hline
\end{tabular}

a Brasseur et al. [1998].

b See text for references.

\subsection{MOZART}

The version of MOZART used in this study is described in detail by Brasseur et al. [1998], and an evaluation of the model by comparison with observations is provided in a companion paper [Hauglustarne et al., 1998]. The model has a horizontal resolution of about $2.8^{\circ}$ latitude by $2.8^{\circ}$ longitude and 25 hybrid $(\sigma-p)$ levels in the vertical extending from the surface to 3 mbar. The numerical time-step for both transport and chem- istry is 20 minutes. MOZART is driven by global wind, temperature, humidity, and cloud fields provided by the NCAR Community Climate Model (CCM, version 2) [Hack et al., 1993], with dynamical variables (including convective mass fluxes and diffusion parameters) provided every 3 hours from preestablished history tapes.

The model accounts for surface emissions of chemical compounds based on the emission inventories as described by Brasseur et al. [1998], advective transport using the semi-Lagrangian transport scheme of William- 
son and Rasch [1994], convective transport using the formulation of Hack [1994] adopted in CCM2, diffusive exchanges in the boundary layer based on the parameterization of Holstag and Boville [1993], wet deposition using the formulation of Brasseur et al. [1998], and dry surface deposition [Müller, 1992]. The chemical scheme includes 140 chemical and photochemical reactions, as well as washout for 10 soluble species.

\subsection{IMAGES}

The major features of IMAGES have been described by Müller and Brasseur [1995]. Model improvement and updates are described by Pham et al. [1995], Granier et al. [1996], and Müller and Brasseur [1999]. The horizontal resolution of the model is $5^{\circ}$ by $5^{\circ}$. In the vertical, there are 25 sigma layers between the surface and the 50 mbar level. Large-scale transport is driven by monthly averaged winds taken from an analysis of the ECMWF. The impact of wind variability at timescales smaller than one month is taken into account as a diffusion process, with diffusion coefficients estimated from the ECMWF wind variances. The water vapor distribution is also provided by the ECMWF analysis. Vertical mixing in the planetary boundary layer is also represented as diffusion. The effect of deep convection on vertical transport is parameterized following the scheme of Costen et al. [1988]. The distribution of cloud updrafts is parameterized using the cumulo-nimbus distribution estimated by the ISCCP project.

The trace gas emissions used in IMAGES are as in Müller and Brasseur [1995], except for the fossil fuel emissions of $\mathrm{NO}_{x}$ and $\mathrm{SO}_{x}$ [Benkovitz et al., 1996] and for the biogenic continental emissions of NMHC [Guenther et al., 1995] and $\mathrm{NO}_{x}$ [Yienger and Levy, 1995]. The lightning source of NO is distributed following Price et al. [1997] in the horizontal, and following Pickering et al. [1998] in the vertical, scaled to a global source of 3 $\mathrm{TgN} / \mathrm{yr}$. The biomass burning emissions are described in Granier et al. [1996], except that higher $\mathrm{NO}_{x}$ to $\mathrm{CO}_{2}$ emission ratios are used [Müller and Brasseur, 1999].

\subsection{Comparisons by Region}

Comparing modeled and observed ozone and its precursors simultaneously in one region can provide a valuable evaluation of the model results. The results from MOZART and IMAGES are shown with the data in Figures 2-4. The MOZART results are shown as a solid line, which represents the mean over the period of the campaign and the horizontal extent of the region, and dotted lines indicating the standard deviation in time over the period of the campaign. The mean over the region from IMAGES is shown as a dashed line. The standard deviation is not shown because IMAGES uses monthly averaged winds and cannot produce the dayto-day variability seen in MOZART.

In the "Africa_S" region (Figure 2), MOZART underestimates both the in situ and DIAL $\mathrm{O}_{3}$ measurements by $20-40$ ppbv throughout most of the troposphere.
The results from IMAGES also underestimate the observations, but are within 5-10 ppbv of the data in the upper troposphere. However, the IMAGES profile has a minimum at about $4 \mathrm{~km}$ that is not evident in either the MOZART profile or the observations. IMAGES slightly underestimates $\mathrm{NO}_{x}$, perhaps caused by lower biogenic and lightning emissions than MOZART (see Table 4) as well as the "c"-shaped profile used for lightning emissions. However, the total biomass burning emissions are slightly larger in IMAGES than in MOZART and this is a region and time where burning is a significant source. MOZART and IMAGES do not include direct emissions of peroxides in biomass burning, which the profiles of $\mathrm{H}_{2} \mathrm{O}_{2}$ and $\mathrm{CH}_{3} \mathrm{OOH}$, as well as other analyses of the data [Lee et al., 1998], indicate may occur. It is difficult to draw conclusions about the ability of these 3-D models to reproduce the observed PAN $/ \mathrm{NO}_{x}$ and $\mathrm{HNO}_{3} / \mathrm{NO}_{x}$ ratios as there are very few data, and they show a wide range of values. However, comparison of the MOZART and IMAGES ratios indicates the two models have very different partitioning of the $\mathrm{NO}_{y}$ species, with IMAGES having greater $\mathrm{HNO}_{3} / \mathrm{NO}_{x}$ in the lower troposphere and greater $\mathrm{PAN} / \mathrm{NO}_{x}$ in the upper troposphere than MOZART. The higher PAN/NO ratio may be due to the larger isoprene emissions used in IMAGES. The ratio of $\mathrm{C}_{3} \mathrm{H}_{8} / \mathrm{C}_{2} \mathrm{H}_{6}$ in IMAGES increases sharply above $6 \mathrm{~km}$, greatly differing from the data and results from MOZART, and highlighting the increase in $\mathrm{C}_{3} \mathrm{H}_{8}$. This indicates IMAGES has strong convection in this region, consistent with the increase with altitude above $6 \mathrm{~km}$ in $\mathrm{O}_{3}, \mathrm{CO}, \mathrm{PAN}$, and acetone, as well as ethane and propane. The decreases in $\mathrm{HNO}_{3}$ and $\mathrm{H}_{2} \mathrm{O}_{2}$ in the upper troposphere indicate the influence of rain with the convection, however the ratio of $\mathrm{H}_{2} \mathrm{O}_{2} / \mathrm{CH}_{3} \mathrm{OOH}$ indicates that the washout in the models is too high. Acetone is reasonably well reproduced by both models, but formaldehyde is under-estimated at the surface and overestimated in the mid-troposphere. The 3-D model ozone production and loss rates agree fairly well with the box model calculations, particularly above $5 \mathrm{~km}$, where both drop significantly. In the lower troposphere there is a large amount of scatter in the box model calculations and IMAGES has loss rates that are several times higher than those in MOZART, due to its higher values of $\mathrm{O}_{3}$ and lower NO than MOZART.

There are a number of factors affecting both the observations and model results in the "Africa $S$ " region, making it difficult to conclude the true degree of agreement and discrepancy between the data and models. The model results are affected by the location and strength of the biomass burning emissions of a number of species $\left(\mathrm{NO}_{x}, \mathrm{CO}, \mathrm{NMHCs}\right.$, acetone) and the data by the precise location of fires in relation to the observations. The distributions in the middle and upper troposphere are strongly affected by convection, which can be quite variable during any measurement campaign and may not be properly represented in the models.

In Figure 3, the "Japan" region for PEM-West-B, the ozone values from IMAGES are much higher than both 
the observations and the MOZART profile, except for the highest observations at $8-12 \mathrm{~km}$, which were likely influenced by, if not obtained in, the lower stratosphere. As there are not similarly large discrepancies in other species (except perhaps acetone) and the ozone production and loss rates agree, this likely indicates that the rate of transport from the stratosphere is too great in this altitude-region in IMAGES. A similar conclusion was drawn from comparisons with MOZAIC [Law et al., 2000]. Both MOZART and IMAGES produce slightly high values of $\mathrm{NO}$ and $\mathrm{NO}_{x}$ at the surface, but agree well throughout the free troposphere. $\mathrm{CO}$ is reproduced well, however, MOZART underestimates the $\mathrm{C}_{3} \mathrm{H}_{8}$ mixing ratios in the lower troposphere by $30-50 \%$, caused by the lower industrial $\mathrm{C}_{3} \mathrm{H}_{8}$ emissions in MOZART than in IMAGES. Both models have higher values of $\mathrm{HNO}_{3}$ than the observations, perhaps due to rain-out processing of the observed air masses, whereas the PAN from MOZART matches the data well. Again, the $\mathrm{NO}_{y}$ partitioning is quite different in the two models, perhaps caused by the higher NMHC levels in IMAGES than MOZART, leading to production of more PAN. In this region, the models overestimate the peroxides in the lower half of the troposphere, although the ratio $\mathrm{H}_{2} \mathrm{O}_{2} / \mathrm{CH}_{3} \mathrm{OOH}$ agrees with the observed ratio. This agreement may just be fortuitous, but may also indicate that the models overestimate the $\mathrm{HO}_{x}$ concentrations, which would equally affect $\mathrm{H}_{2} \mathrm{O}_{2}$ and $\mathrm{CH}_{3} \mathrm{OOH}$. IMAGES greatly overestimates acetone in the lower and middle troposphere, which must be due to its higher biogenic and biomass burning emissions, although it would be expected that industrial emissions would be more significant in this region. It is interesting to note that the two models calculate the same profile for $\mathrm{HCHO}$ (though there are no data available), probably due to their similar emissions and having similar $\mathrm{HC}$ oxidation schemes. IMAGES calculates much higher $\mathrm{O}_{3}$ production and loss rates, with net production falling slightly below MOZART and the box model calculations, as a result of the higher ozone values in IMAGES.

The comparison of the models with data may be better in the Japan region than the "Africa_S" region due to the observations being farther from source emissions in Asia, and therefore not affected by the precise location of sources. Perhaps, also, the Asian industrial sources are more accurately quantified than the African biomass burning emissions.

The "Tahiti" region from PEM-Tropics-A is shown in Figure 4. The models do not reproduce the ozone peak in the observations at 3-6 km, although IMAGES shows a slight maximum there. The values of observed $\mathrm{NO}_{x}$ seem to be captured by both models, but $\mathrm{NO}$ is generally underestimated, which could be the cause of the underestimation of ozone. Slight peaks, or greater variability, can be seen in the observations of $\mathrm{CO}, \mathrm{C}_{2} \mathrm{H}_{6}$, PAN, and $\mathrm{HNO}_{3}$ between 3 and $6 \mathrm{~km}$, consistent with plumes from biomass burning being encountered by the aircraft [Hoell et al., 1999] that was not reproduced in the models, probably due to insufficient resolution and/or a difference in modeled dynamics from the actual winds. Overall, the models show reasonable agreement with the observations of $\mathrm{CO}$. The observed values of $\mathrm{C}_{2} \mathrm{H}_{6}$ are bracketed by the models throughout the troposphere, with the difference between the models an indication of differences in long-range transport. The models do not show any indication of the observed peak in PAN at $3-7 \mathrm{~km}$, but IMAGES produces a peak in $\mathrm{HNO}_{3}$ there. MOZART results for $\mathrm{HNO}_{3}$ lie within the observed values, but do not drop off in the upper troposphere. $\mathrm{H}_{2} \mathrm{O}_{2}$ and $\mathrm{CH}_{3} \mathrm{OOH}$ in the models reproduce the maximum in the profiles at the top of the boundary layer $(2 \mathrm{~km})$ though slightly underestimate the peak value. Once again, there are very few $\mathrm{PAN} / \mathrm{NO}_{x}$ and $\mathrm{HNO}_{3} / \mathrm{NO}_{x}$ data points, and the models show very different ratios. The underestimation of $\mathrm{PAN} / \mathrm{NO}_{x}$ in the models below $7 \mathrm{~km}$ is due primarily to the underestimation of PAN, coincident with an overestimation of $\mathrm{HNO}_{3} / \mathrm{NO}_{x}$. The global models reproduce the box model calculations of very low rates of $\mathrm{P}\left(\mathrm{O}_{3}\right)$ and $\mathrm{L}\left(\mathrm{O}_{3}\right)$ fairly well.

\subsection{Comparison of One Species in Several Regions}

It is also valuable to compare many regions at one time for each species, which can allow identification of systematic differences between the model results and observations. The comparison of data and models for "Africa_S" (Figure 2) indicated that perhaps biomass burning emissions and/or convection were too low, and we have examined other regions where burning occurs. Figures 8-13 present $\mathrm{O}_{3}, \mathrm{CO}, \mathrm{NO}, \mathrm{PAN}, \mathrm{HNO}_{3} / \mathrm{NO}_{x}$, and acetone for regions that are influenced by emissions from biomass burning. In most of these regions, MOZART, and to a lesser extent IMAGES, underestimate the observations of ozone (Figure 8). However, in general, the observations of CO (Figure 9) are reproduced by both models, although for TRACE-A/"BrazilE" and PEM-Tropics-A/ "Fiji" the models fall short of the observations. Underestimation of ozone often coincides with an underestimation of NO (Figure 10), implying that the $\mathrm{NO}$ emissions are too low, or the formation of reservoirs is too high, as indicated by $\mathrm{HNO}_{3} / \mathrm{NO}_{x}$ being too high. In some cases the models are low by only a few pptv, but this can correspond to a significant fraction of the total NO. As was shown in Figure 5a, the ozone observations in the "Fiji" region were significantly higher than the ozonesonde climatology at Samoa, and so may not be suitable for comparison with these climatological models. The observed values of PAN (Figure 11) cover a wide range of values, both within and among regions. In almost all cases MOZART values are less than IMAGES and are often less than observations, except for ABLE-2B, where both models are high. Both MOZART and IMAGES significantly underestimate the PEM-Tropics-A observations in the middle troposphere, as discussed above in the discussion on "Tahiti" and Figure 4. For $\mathrm{HNO}_{3} / \mathrm{NO}_{x}$, the models are high except for "Africa_S" and "Fiji" (Figure 12). For "Fiji" the 

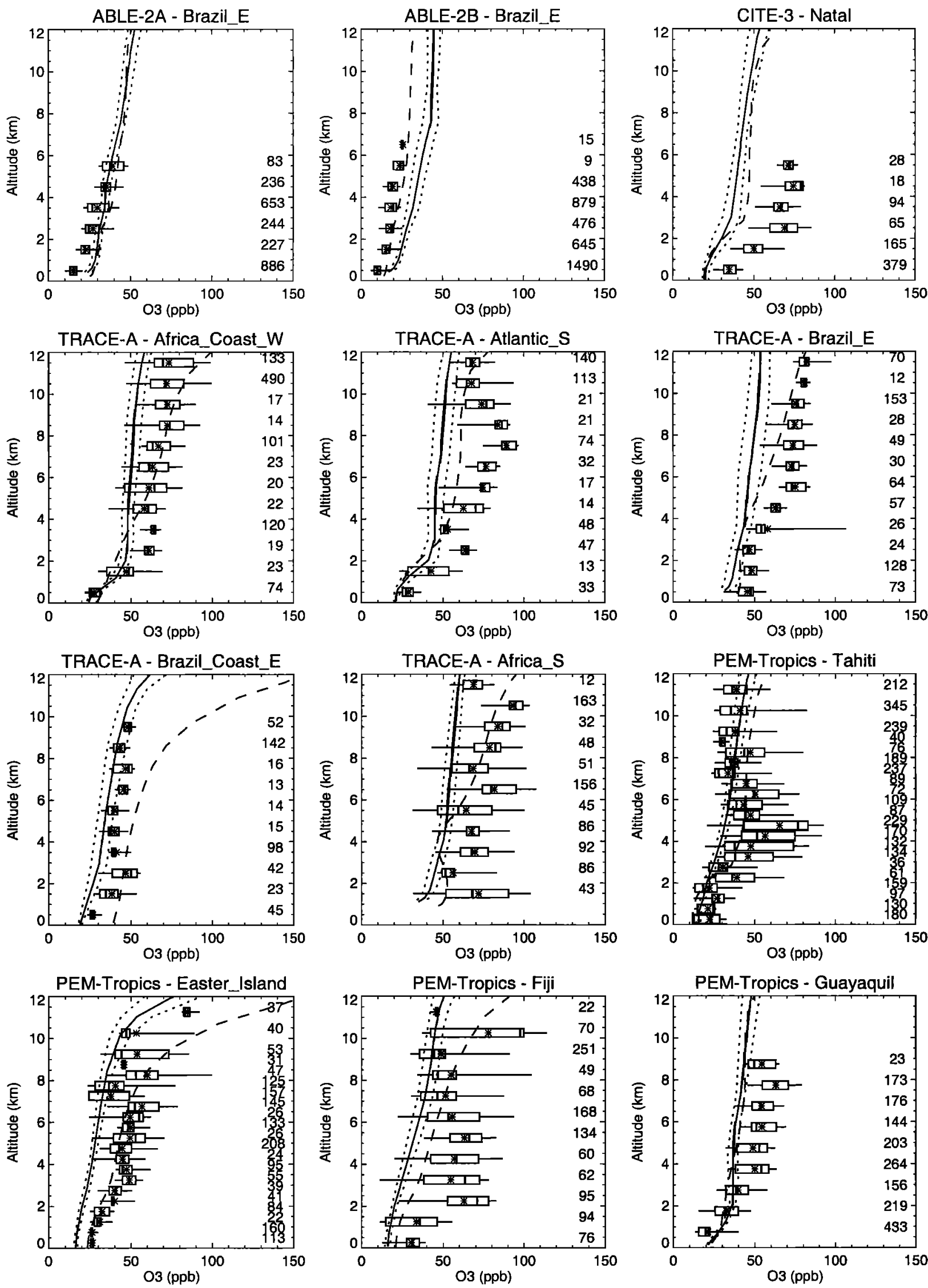

Figure 8. Ozone profiles for regions influenced by biomass burning. 

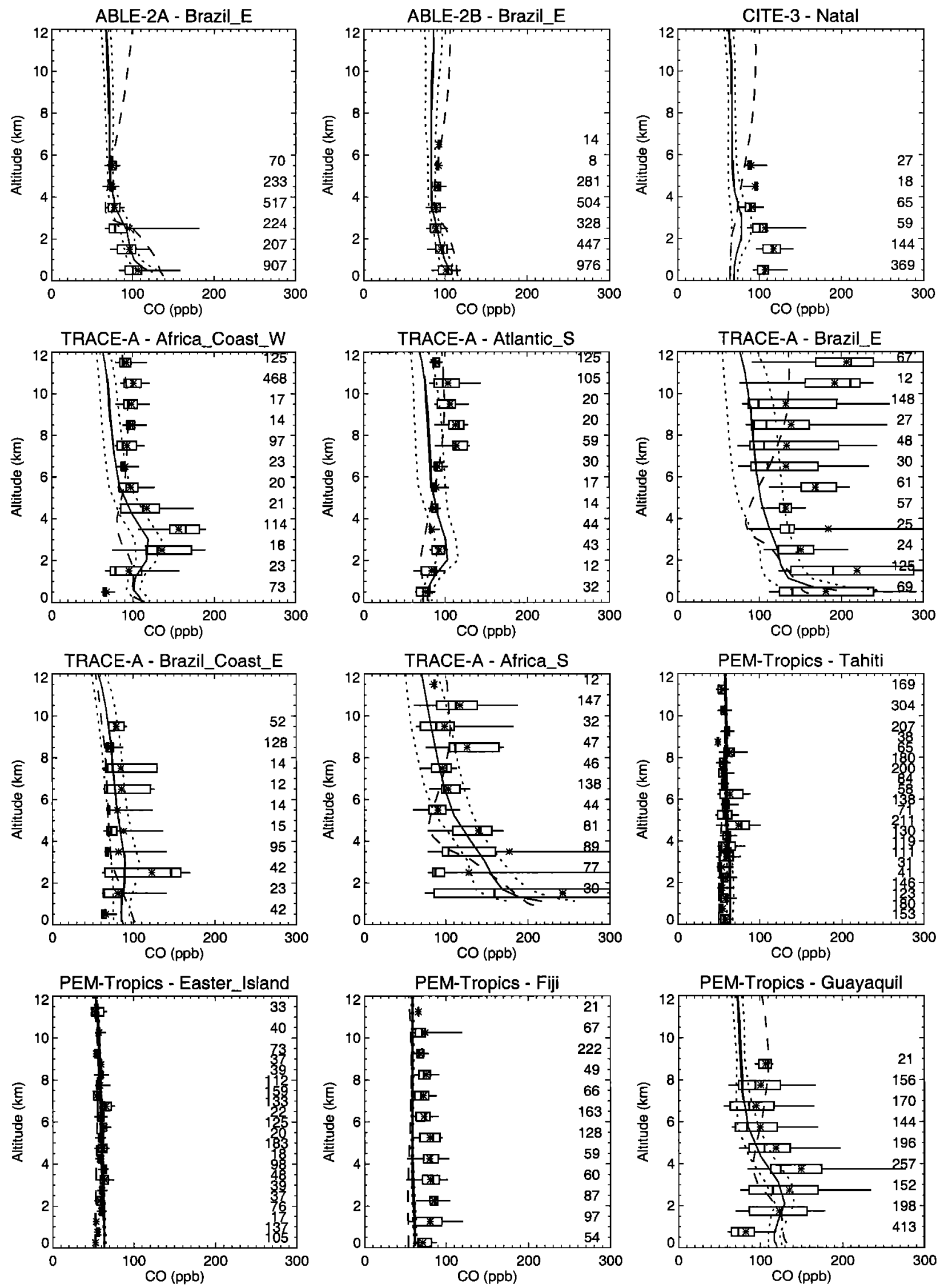

Figure 9. CO profiles for regions influenced by biomass burning. 

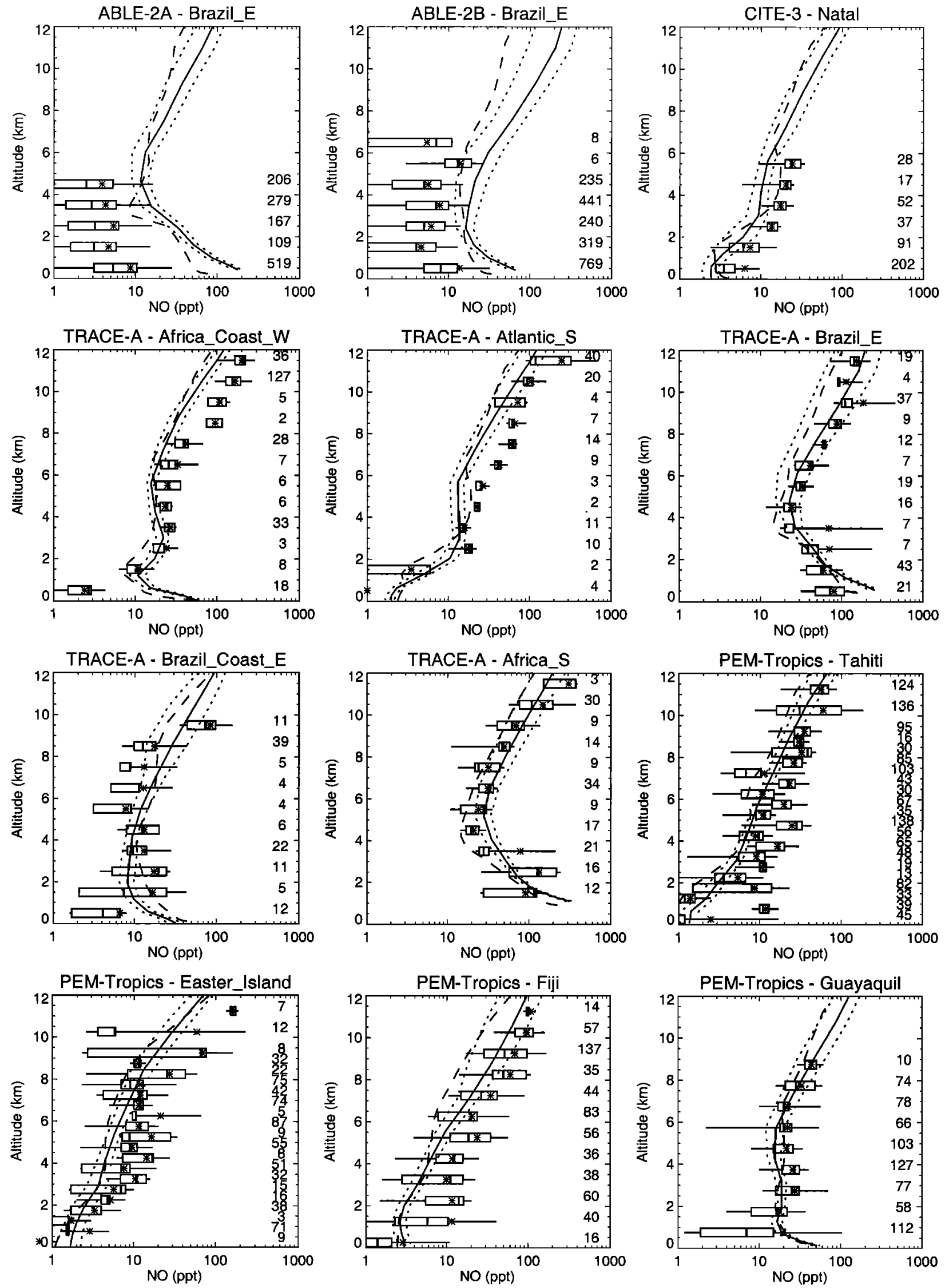

Figure 10. NO profiles for regions influenced by biomass burning. 

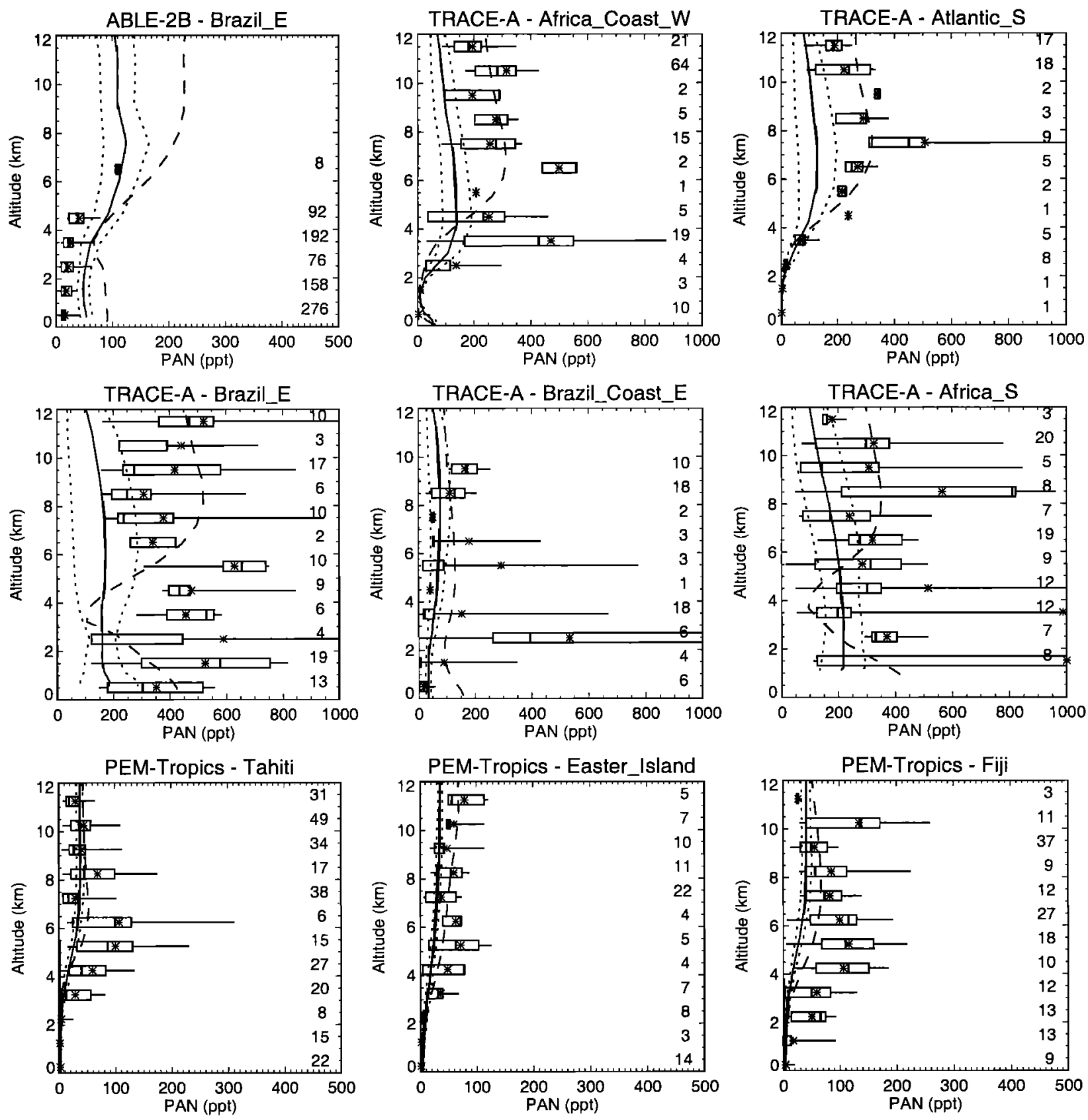

Figure 11. PAN profiles for regions influenced by biomass burning.

MOZART results for $\mathrm{HNO}_{3}$ and $\mathrm{NO}_{x}$ are too low (not shown), and it is only fortuitous that the ratio agrees with the observations. There are few measurements of acetone (Figure 13), but IMAGES matches them well. The MOZART calculations of acetone are too low in the upper troposphere, and lower than IMAGES for all regions, an indication of too low emissions and too weak convection (a known symptom of the Hack scheme). The high mixing ratios of PAN calclated by IMAGES (Figure 11) are consistent with the high acetone levels in the upper troposphere since PAN is produced in the breakdown of acetone [Singh et al., 1995].

The conclusions drawn here about the ability of MOZART to reproduce the tropospheric observations presented here agree, in general, with those presented by Hauglustaine et al. [1998]. However, the limitations of MOZART to reproduce ozone, as well as nitrogen species, in biomass burning regions has been made more evident in these comparisons. The fair agreement between IMAGES and observations shown by Müller and Brasseur [1995], as well as the ability of IMAGES to reproduce acetone measurements [Müller and Brasseur, 1999] are also shown here.

\subsection{Comparison of Variability}

Another measure of the ability of a model to reproduce the actual atmosphere, can be obtained through comparisons of the range of variability produced by the 
model with the range of the observations. IMAGES uses a 1-day time step and monthly averaged meteorology, whereas MOZART has a 20-min time step and uses 6-hour average meteorology. Therefore IMAGES shows much less variability, and only the results from MOZART will be shown.

Figures 14 and 15 show the frequency distributions of model grid points and observations of $\mathrm{CO}$ and $\mathrm{O}_{3}$ for the "Africa_S" and "Japan" regions for 2-km altitude bins. The MOZART distributions are determined from the grid points within the region for 6 days corresponding to the period during which observations were made, and are shown as solid lines. The observations are shown by dotted lines. The MOZART results shown here are based on 24-hour averages (due to storage space limitations), although the model time step is $20 \mathrm{~min}$, so the actual model variability is likely to be underestimated by this representation. The mixing ratio bins are $5 \mathrm{ppbv}$ for $\mathrm{O}_{3}$ and $10 \mathrm{ppbv}$ for $\mathrm{CO}$, and the probability distributions have been normalized by the total number of points in each altitude bin.

In the "Africa_S" region (Figure 14) the observed variability of $\mathrm{O}_{3}$ (left panels) is greater than in the model results, implying that the model does not reproduce small-scale plumes of high $\mathrm{O}_{3}$ produced from fire and lightning emissions, that the aircraft sampled [Fishman et al., 1996]. In the models, high emissions from a relatively small source (e.g., a fire or thunderstorm)
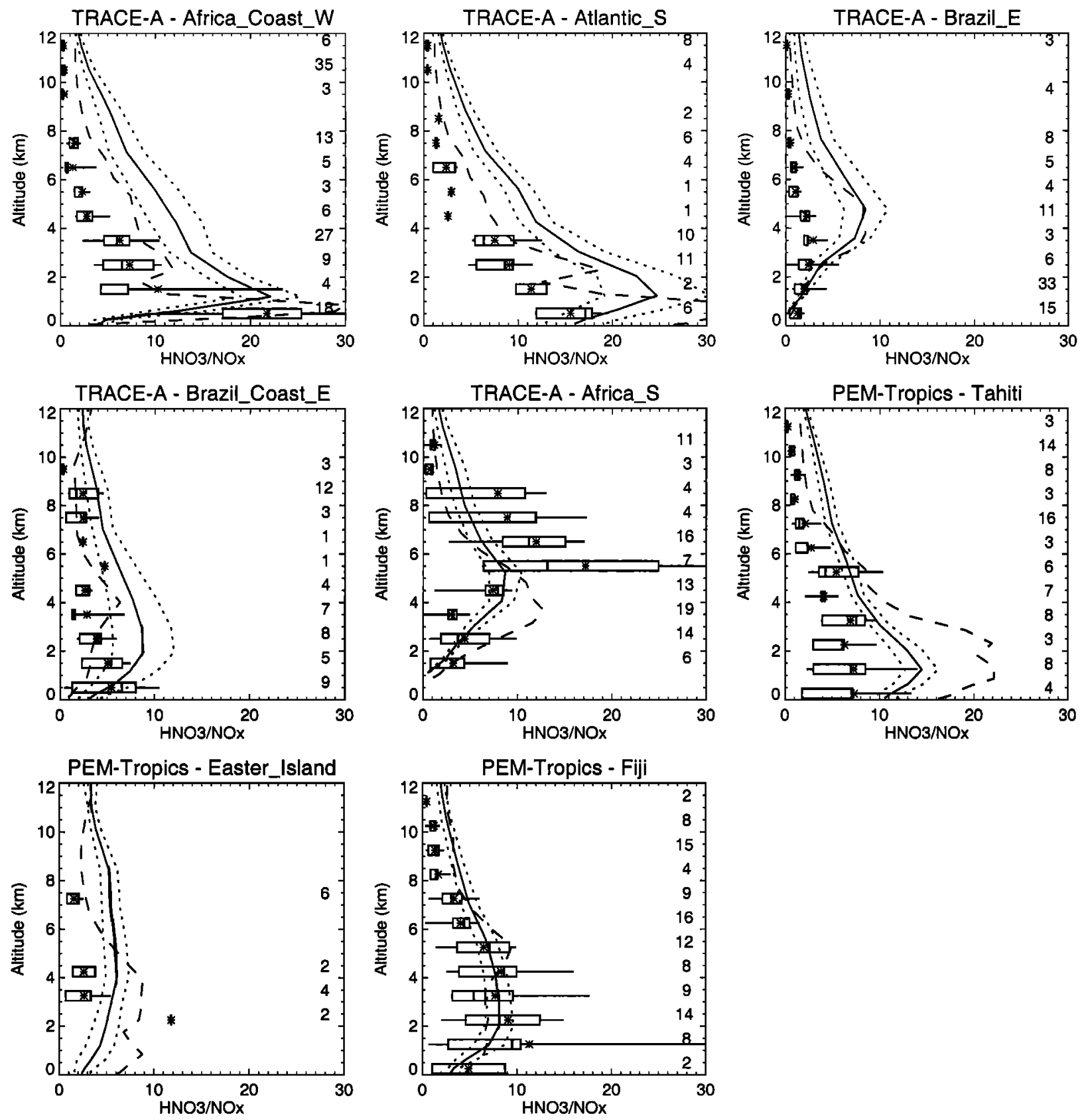

Figure 12. $\mathrm{HNO}_{3} / \mathrm{NO}_{x}$ profiles for regions influenced by biomass burning. 

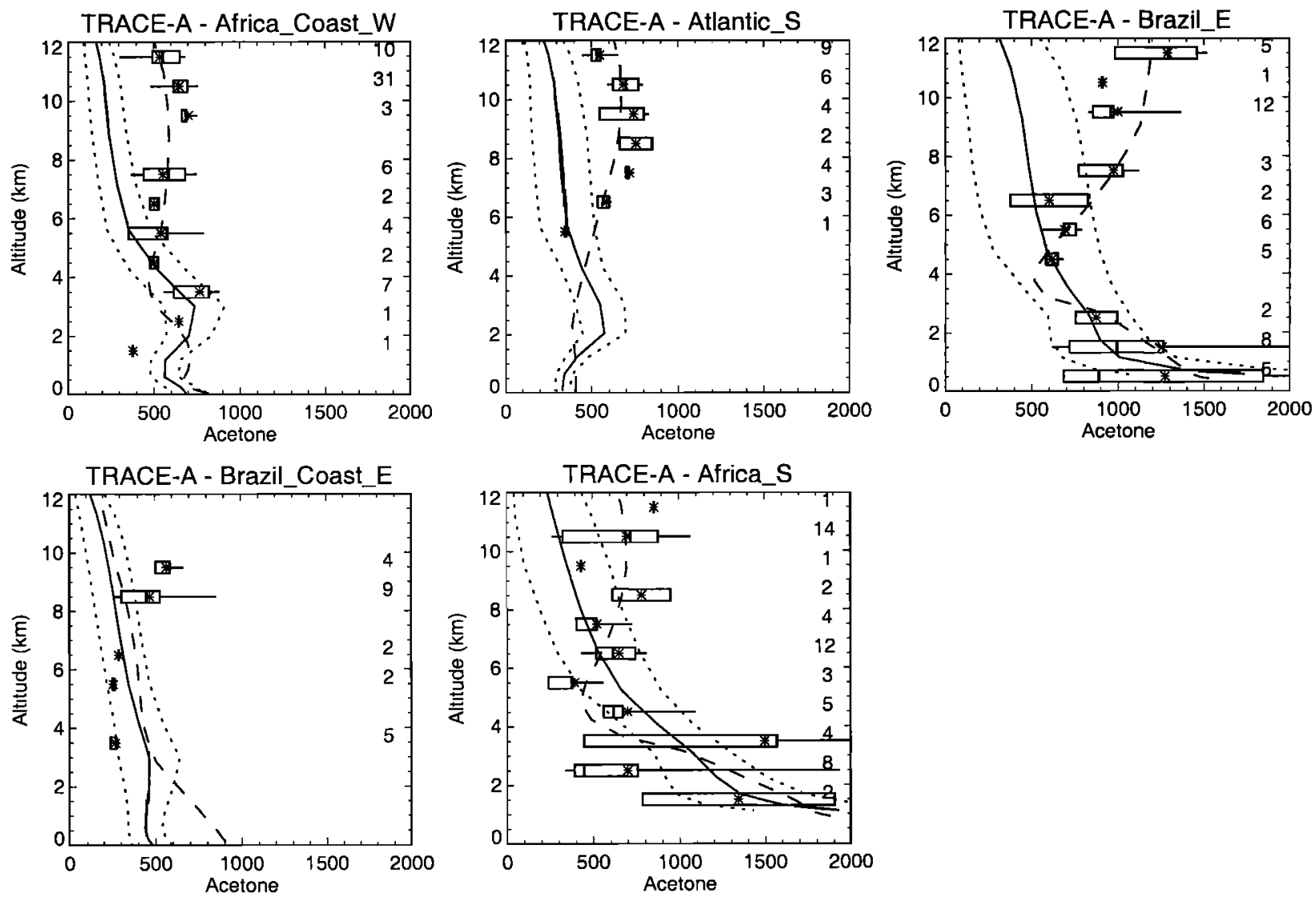

Figure 13. Acetone profiles for regions influenced by biomass burning.

must be represented as an average value for the grid box in which it occurs, effectively diluting the source emission. The emissions are also set as monthly averages, which results in further dilution. The peaks in the MOZART distributions are significantly less than the observations, particularly at low altitudes. The frequency distributions of the $\mathrm{CO}$ observations and calculations (right panels) are similar, except in the upper troposphere, where high values ( 300 to $>500 \mathrm{ppbv}$ ) were observed but not reproduced. This could be due to insufficient convection of biomass burning emissions, or the inability to reproduce small-scale plumes.

In the "Japan" region (Figure 15) the frequency distributions of $\mathrm{O}_{3}$ and $\mathrm{CO}$ are very similar for model and data. The MOZART results generally reproduce the observed values, especially in the middle troposphere. Although $\mathrm{O}_{3}$ is underestimated and $\mathrm{CO}$ overestimated in the lower troposphere, the width of the distributions are similar. As in Figure 14, MOZART underestimates $\mathrm{CO}$ in the upper troposphere, which could again indicate insufficient convection in the model. Although there are some discrepancies, it appears that the results from MOZART are, in general, capable of reproducing variations comparable to true atmospheric variability.

\section{Summary}

In this paper, we have presented data composites created from aircraft measurements of ozone and its pre- cursors. Data from each measurement campaign have been gridded to $5^{\circ}$ by $5^{\circ}$ by $1 \mathrm{~km}$ boxes. In addition, vertical profiles have been created for selected regions. The gridded data plotted on maps for given altitudes help provide an overall view of the available measurements, while the vertical profiles are particularly useful for model evaluation.

There clearly remain significant gaps in our knowledge of the distribution of ozone and its precursors in the troposphere. Although intensive aircraft campaigns have greatly added to our understanding of species' distributions in a number of regions during one or two seasons (the western Pacific, South Pacific, and South Atlantic basin, for example) we are still far from having sufficient data to determine climatologies of these tropospheric species from observations alone. The data composites shown here are a means of summarizing a major part of our current knowledge of atmospheric distributions based on selected field campaigns, and provide a framework for the addition of future measurements.

Improved measurement capabilities would also greatly improve our ability to evaluate global models. Significant questions remain about our ability to accurately measure $\mathrm{HNO}_{3}$ and $\mathrm{NO}_{y}$, which are two observations that can provide significant information regarding photochemical processes in the troposphere. More measurements of acetone and formaldehyde, as well as direct measurements of $\mathrm{HO}_{x}$ in the upper troposphere 
are needed to address questions about the $\mathrm{HO}_{x}$ budget. Many of the measurement techniques currently used on research aircraft require continuous attention for successful operation. If more automated techniques were developed, these instruments could be used on commercial aircraft, such as in the MOZAIC and NOXAR programs, and would provide valuable long-term measurements.
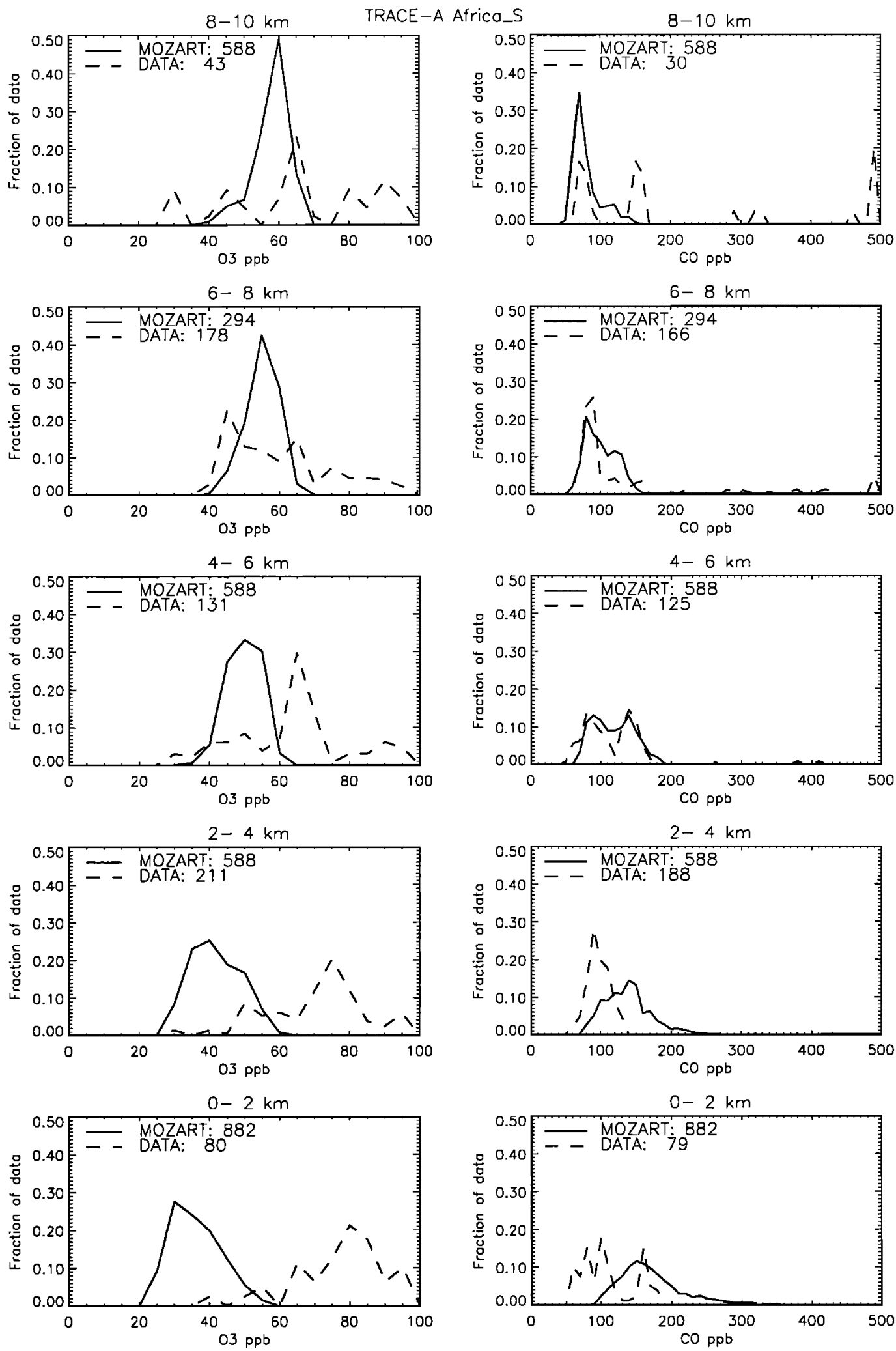

Figure 14. Comparison of frequency distributions in 2-km altitude bins of modeled (for October 3-8) and observed $\mathrm{O}_{3}$ and $\mathrm{CO}$ for the TRACE-A "Africas" region. Mixing ratio bins are $5 \mathrm{ppbv}$ for $\mathrm{O}_{3}$ and $10 \mathrm{ppbv}$ for $\mathrm{CO}$. 

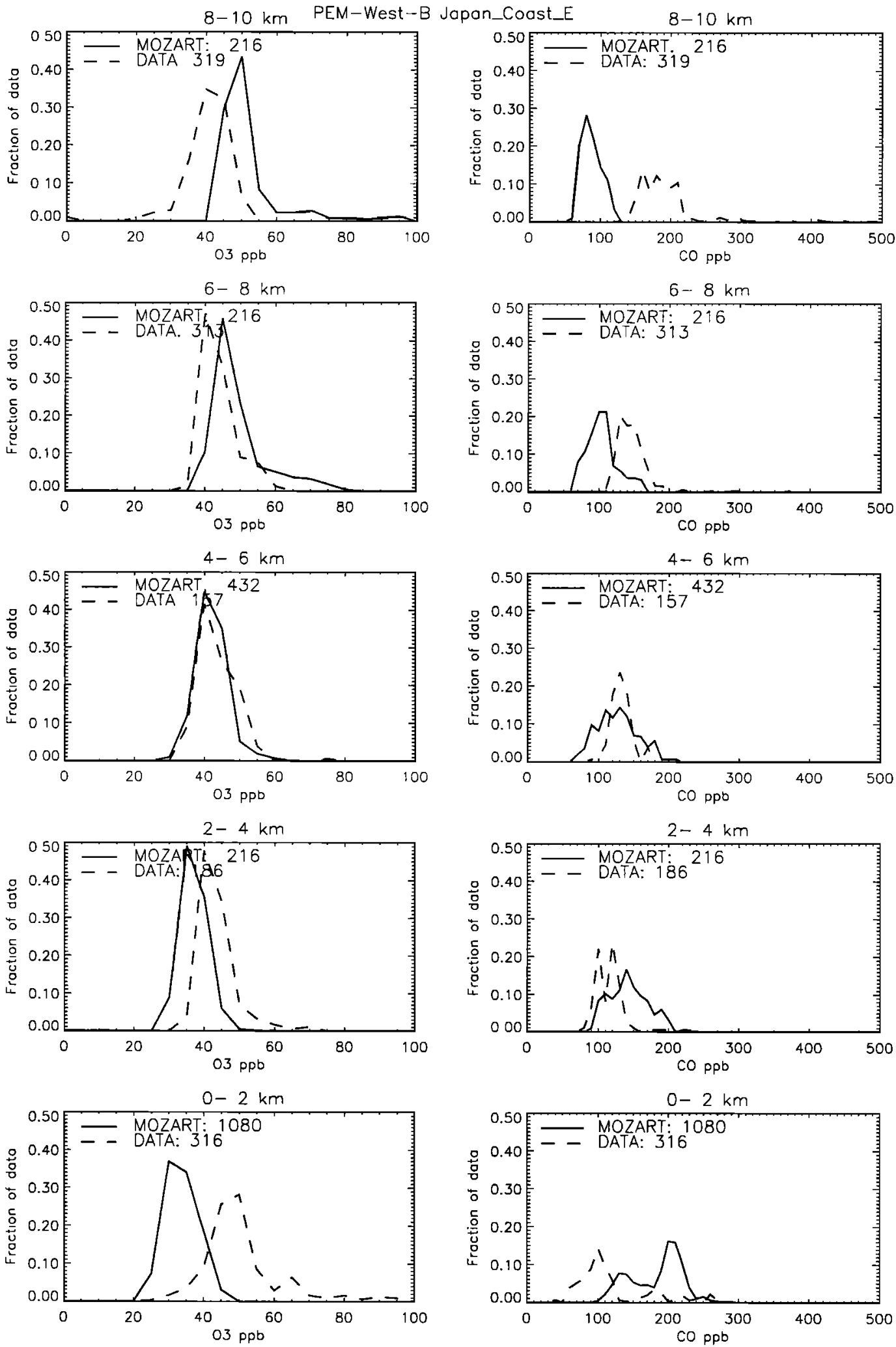

Figure 15. As in Figure 14, for the PEM-West-B "Japan_CoastE" region, March 7-12.

Several examples of how these data composites can be used to evaluate global models have been shown and compared with two global CTMs, MOZART, and IMAGES. Comparisons were made for a number of species in three regions, as well as for single species in sev- eral regions. Frequency distributions were also shown as a way to evaluate model results. From the results of PEM-Tropics-A and TRACE-A it is evident that biomass burning has a strong influence on the atmospheric composition of the Southern Hemisphere during 
the dry season. The comparisons for southern Africa and other biomass burning regions indicate that the magnitude, and perhaps location, of burning is not completely understood or correctly modeled. Additional measurements in South America, Africa, and Southeast Asia during both $\mathrm{NH}$ and $\mathrm{SH}$ burning seasons of directly emitted species $\left(\mathrm{CO}, \mathrm{NO}_{z} . \mathrm{N} \mathrm{NHHCs}\right)$ as well as their photochemical products $\left(\mathrm{PAN} . \mathrm{HNO}_{3}, \mathrm{O}_{3}\right.$ ) would greatly improve our understanding of the influence of biomass burning on the troposphere. Comparisons of observations with models using analyzed winds for the specific year of observations would reduce a possible source of disagreement and allow a better determination of errors in the modeled chemistry.

Many questions remain about the accuracy of modeled convection and the quantity and vertical distribution of $\mathrm{NO}_{x}$ produced by lightning. Additional measurements of $\mathrm{NO}_{x}$ and surface-emitted tracers around thunderstorms could greatly improve our understanding of the degree of transport between the surface and the upper troposphere.

The anthropogenic influences in the Northern Hemisphere have far-reaching effects. Continued measurements in the western Pacific will be needed to assess the impact of increasing emissions in Asia on the downwind regions of the Pacific basin and North America [Jacob et al.. 1999; Berntsen et al., 1999]. Also, additional measurements are needed to determine the effect of North American emissions on Europe and European emissions on Asia. Understanding these influences is critical in determining the requirements for restrictions on emissions in order to preserve air quality and mitigate climate change.

The data composites presented here will continue to be expanded as new data sets become available. Additional species (e.g., $\mathrm{H}_{2} \mathrm{O}, \mathrm{CH}_{4}$, other $\mathrm{NMHCs}$, including isoprene, sulfur, and halogen compounds), as well as aerosol concentrations and composition will also be added. These data sets will continue to be used in the evaluation of models under development and in comparison with satellite measurements.

Acknowledgments. Many thanks to all of the investigators who have made all of the observations presented here and made them available. The merged data files generated by Scott Sandholm at Georgia Tech were gratefully used. Thanks to J. Crawford and M. Schultz for providing box model calculations. For $\mathrm{ACE}-1$ data, $\mathrm{O}_{3}$ and $\mathrm{CO}$ were made available by G. Kok, A. Prévôt, and R. Schillawski; NMHCs wre from D. Blake; peroxides were from G. Kok; ozonesondes were from J. Johnson; all through the UCAR/CODIAC server The many helpful comments from $D$. Kinnison, L. Horowitz, B. Ridley, and J. Logan are gratefully acknowledged. The careful reading and suggestions from $M$. Lawrence and two anonymous reviewers are much appreciated. This work was funded by NASA Subsonic Assessment project (grant NAG 5-3168) and NASA Atmospheric Chemistry Modeling and Analysis Program (grant L-9301), as well as a grant of the Belgian Office for Scientific. Technological and Cultural Affars (OSTC). The National Center for
Atmospheric Research is operated by the University Corporation for Atmospheric Research and sponsored by the National Science Foundation.

\section{References}

Anderson, B.E., G.L. Gregory, J.D.W. Barrick, J.E. Collins Jr., G.W. Sachse, D. Bagwell, M.C. Shipham, J.D. Bradshaw, and S.T. Sandholm, The impact of L.S. continental outflow on ozone and aerosol distributions over the western Atlantıc, J. Geophys. Res., 98, 23,477-23,489, 1993a.

Anderson, B.E. G.L. Gregory, J.D.W. Barrick, J.E. Collins, G.W. Sachse, C.H. Hudgins, J.D. Bradshaw, and S.T. Sandholm, Factors influencing dry season ozone distributions over the tropical South Atlantic, J. Geophys. Res., 98, 23,491-23,500, 1993b.

Anderson, B.E.. J.E. Collins Jr., G.W. Sachse. G.W. Whiting, D.R. Blake, and F.S. Rowland, AASE-II in-situ tracer correlations of methane, nitrous oxide, and ozone as observed aboard the DC-8, Geophys. Res. Lett., 20, 25392542, 1993c

Anderson, B.E., G.L. Gregory, J.D. Barrick, J.E. Collins Jr., G.W. Sachse, M.C. Shipham, and C.H. Hudgins. Summertime tropospheric ozone distributions over central and eastern Canada, J. Geophys. Res., 99, 1781-1792, 1994.

Anderson, J.G., and O.B. Toon, Airborne Arctic Stratospheric Expedition II: An overview, Geophys. Res. Lett., 20, 2499-2502, 1993.

Arlander, D.W., D. Brüning, U. Schmidt. and D.H. Ehhalt, The tropospheric distribution of formaldehyde during TROPOZ II, J. Atmos. Chem., 22, 251-268, 1995.

Atlas, E.L., and B.A. Ridley, The Mauna Loa Observatory Photochemistry Experiment: Introduction, J. Geophys. Res., 101, 14.531-14,541, 1996.

Bachmeier, A.S., and H.E. Fuelberg, A meteorological overview of the TRACE-A period, J. Geophys. Res., 101, 23,881-23,888, 1996.

Bachmeier, A.S., R.E. Newell, M.C. Shipman, Y. Zhu, D.R. Blake, and E.V. Browell, PEM-West A: Meteorological overview, J. Geophys. Res., 101, 1655-1677, 1996.

Bates, T.S., B.J. Huebert, J.L. Gras, F.B. Griffiths, and P.A. Durkee, International Global Atmospheric Chemistry (IGAC) Project's First Aerosol Characterization Experiment (ACE 1): Overview, J. Geophys. Res., 103, $16.297-16,318,1998$.

Beck, S.M., et al., Operational overview of NASA GTE/CITE-1 airborne instrument intercomparisons: Carbon monoxide, nitric oxide, and hydroxyl instrumentation, J. Geophys. Res., 92, 1977-1985, 1987.

Benkovitz, C.M., J. Dignon, J. Pacyna. T. Scholtz, L. Tarrason, E. Voldner, and T.E. Graedel, Global inventories of anthropogenic emissions of $\mathrm{SO}_{2}$ and $\mathrm{NO}_{x}, J$. Geophys. Res.; 101, 29,239-29,253, 1996.

Berntsen, T.K.. S. Karlsdottir, and D.A. Jaffe, Influence of Asian emissions on the composition of air reaching the northwestern United States, Geophys. Res. Lett., 26, 2171-2174, 1999.

Blake, D.R., D. Hurst, T. Smith Jr., W. Whipple, T.-Y. Chen, N. Blake, and F.S. Rowland, Summertime measurements of selected nonmethane hydrocarbons in the Arctic and Subarctic during the 1988 Arctic Boundary Layer Expedition (ABLE 3A), J. Geophys. Res., 97, 16,559-16,588, 1992.

Blake, D.R., T. Smith Jr., T.-Y. Chen, W. Whipple, and F.S. Rowland, Effects of biomass burning on summertime nonmethane hydrocarbon concentrations in the Canadian wetlands, J. Geophys. Res., 99, 1699-1719, 1994.

Boissard, C., B. Bonsang, M. Kanakidou, and G. Lambert, 
TROPOZ II: Global distributions and budgets of methane and light hydrocarbons, J. Atmos. Chem., 25. 115-148, 1996.

Bradshaw, J., S. Sandholm, and R. Talbot, An update on reactive odd-nitrogen measurements made during recent NASA Global Tropospheric Experiment programs, J. Geophys. Res., 103, 19,129-19,148, 1998.

Bradshaw, J., et al., Photofragmentation two-photon laserinduced fluorescence detection of $\mathrm{NO}_{2}$ and $\mathrm{NO}$ : Comparison of measurements with model results based on airborne observations during PEM-Tropics A. Geophys. Res. Lett., 26, 471-474. 1999.

Bradshaw, J.D., et al., Observed distributions of nitrogen oxides in the remote free troposphere from the NASA Global Tropospheric Experiment programs, Rev. Geophys., 38, 61-116. 2000.

Brasseur, G.P., D.A. Hauglustaine, S. Waiters, P.J. Rasch, J.-F. Müller. C. Granier, and X.-X. Tie, MOZART: A global chemical transport model for ozone and related chemical tracers, 1, Model description, J. Geophys. Res., 103, 28,265-28,289, 1998.

Brenninkmeijer, C., et al., CARIBIC - Civil aircraft for global measurement of trace gases and aerosols in the tropopause region, J. Atmos. Oceanıc Technol, , 16, 1373$1383,1999$.

Browell, E.V., C.F. Butler, S.A. Kooi, M.A. Fenn, R.C. Harriss, and G.L. Gregory, Large-scale variability of ozone and aerosols in the summertime Arctic and subarctic troposphere, J. Geophys. Res., 97, 16,433-16.450, 1992.

Browell, E.V.. M.A. Fenn, C.F. Butler, W.B. Grant, R.C. Harriss, and M.C. Shipham, Ozone and aerosol distributions in the summertime troposphere over Canada, $J$. Geophys. Res., 99, 1739-1755, 1994.

Brunner, D., J. Staehelin, and D. Jeker, Large-scale nitrogen oxide plumes in the tropopause region and implications for ozone, Science, 282, 1305-1309, 1998.

Campos, T.L., et al., Measurement of $\mathrm{NO}$ and $\mathrm{NO}_{y}$ emission indices during SUCCESS, Geophys. Res. Lett., 25, 1713$1716,1998$.

Costen, R.C., G.M. Tennille, and J.S. Levine, Cloud pumping in a one-dimensional model, J. Geophys. Res., 93, $15,941-15,954,1988$

Crawford, J., et al., Photostationary state analysis of the $\mathrm{NO}_{2}$-NO system based on airborne observations from the western and central North Pacific, J. Geophys. Res., 101, 2053-2072, 1996.

Crawford, J., et al., An assessment of ozone photochemistry in the extratropical western North Pacific: Impact of continental outflow during the late winter/early spring, $J$. Geophys. Res., 102, 28,469-28,487, 1997.

Crosley, D.R., Issues in the measurement of reactive nitrogen compounds in the atmosphere, SRI Int. Rep. MP 94-035, SRI Int., Menlo Park, Calif., 1994.

Crosley, D.R., $\mathrm{NO}_{y}$ blue ribbon panel, J. Geophys. Res., 101, 2049-2052, 1996.

Crutzen, P.J., M.G. Lawrence, and U. Poschl, On the background photochemistry of tropospheric ozone, Tellus, Ser. $A-B, 51,123-146,1999$.

Davis, D D., et al., Photostationary state analysis of the $\mathrm{NO}_{2}$-NO system based on airborne observations from the subtropical/tropical North and South Atlantic, J. Geophys. Res., 98, 23,501-23,523, 1993.

Dias-Lalcaca, P., D. Brunner, W. Imfeld, W Moser, and J. Staehelin, An automated system for the measurement of nitrogen oxides and ozone concentrations from a passenger aircraft - instrumentation and first results of the NOXAR project, Environ. Scr. Technol., 32, 3228-3236, 1998.

Drummond, J.W, D.H. Ehhalt, and A. Volz, Measurements of nitric oxide between $0-12 \mathrm{~km}$ altitude and $67^{\circ} \mathrm{N}$ to $60^{\circ} \mathrm{S}$ latitude obtained during STRATOZ III, J. Geophys. Res., 93, 15,831-15,849, 1988.

Ehhalt, D.H., F. Rohrer, and A. Wahner, Sources and distribution of $\mathrm{NO}_{x}$ in the upper troposphere at northern midlatitudes, J. Geophys. Res., 97, 3725-3738, 1992.

Emmons, L.K., et al., Climatologies of $\mathrm{NO}_{x}$ and $\mathrm{NO}_{y}: \mathrm{A}$ comparison of data and models, Atmos. Environ., 31, 1851-1903, 1997.

Emmons, L.K., D.A. Hauglustaine, M.J. Newchurch, T. Takao, K. Matsubara, and G.P. Brasseur, Evidence of transport across the Indian Ocean of ozone produced from biomass burning and lightning, Eos Trans. AGU, 79(45), Fall Meet. Suppl., F111, 1998.

Fehsenfeld, F.C., L.G. Huey, D.T. Sueper, R.B. Norton, E.J. Williams, F.L. Eisele, R.L. Mauldin III, and D.J. Tanner, Ground-based intercomparison of nitric acid measurement techniques, J. Geophys. Res., 103, 3343-3353, 1998.

Fishman, J., and V. Brackett, The climatological distrubution of tropospheric ozone derived from satellite measurements using version 7 Total Ozone Mapping Spectrometer and Stratospheric Aerosol and Gas Experiment data sets, J. Geophys. Res., 102, 19,275-19,278, 1997.

Fishman, J, J.M. Hoell Jr, R.D. Bendura, R.J. McNeal Jr., and V.W.J.H. Kirchoff, The NASA GTE TRACE-A experiment (September-October, 1992): Overview, J. Geophys. Res., 101, 23,865-23,880, 1996.

Fuelberg, H.E., et al., A meteorological overview of the $\mathrm{Pa}$ cific Exploratory Mission (PEM) Tropics period, J. Geophys. Res., 104, 5585-5622, 1999.

Gerbig, C, D. Kley, A. Volz-Thomas, J. Kent, K. Dewey, and D.S. McKenna, Fast response resonance fluorescence $\mathrm{CO}$ measurements aboard the C-130. Instrument characterization and measurements made during North Atlantic Regional Experiment 1993, J. Geophys. Res., 101, 29,22929,238, 1996.

Gouget, H., J-P. Cammas, A. Marenco, R. Rosset, and I. Jonquières, Ozone peaks associated with a subtropical tropopause fold and with the trade wind inversion: A case study from the airborne campaign TROPOZ II over the Carıbean in winter, J. Geophys. Res., 101, 25,97925,993, 1996.

Granier, C., W. M. Hao, G. Brasseur, and J.-F Müller, Land use practices and biomass burning: Impact on the chemical composition of the atmosphere, in Bromass Burning and Global Change, edited by J. S. Levine, pp. 140-148, MIT Press, Cambridge, Mass, 1996.

Greenberg, J.P., D. Helmig, and P.R. Zimmerman, Seasonal measurements of nonmethane hydrocarbons and carbon monoxide at the Mauna Loa Observatory during the Mauna Loa Observatory Photochemistry Experiment 2, J. Geophys. Res., 101, 14,581-14,598, 1996.

Gregory, G.L., E.V. Browell, and L.S. Warren, Boundary layer ozone: An airborne survey above the Amazon Basin, J. Geophys. Res., 93, 1452-1468, 1988.

Gregory, G.L., J.M. Hoell Jr., A.L. Torres, M.A. Carroll, B.A. Ridley, M.O. Rodgers, J. Bradshaw, S. Sandholm, and D.D. Davis, An intercomparison of airborne nitric oxide measurements: A second opportunity, J. Geophys. Res., 95, 10,129-10,138, 1990a.

Gregory, G.L., et al., An intercomparison of airborne nitrogen dioxide instruments, $J$. Geophys. Res., 95, 10,10310,127, 1990b.

Gregory, G.L., J.M. Hoell Jr., B.A. Ridley, H.B. Singh, B. Gandrud, L.J. Salas, and J. Shetter, An intercomparison of airborne PAN measurements, J. Geophys. Res., 95, 10,077-10,087, 1990c

Gregory, G.L., et al., An intercomparison of airborne nitric acid measurements, J. Geophys. Res., 95, 10,089-10,102, 1990d. 
Gregory, G.L., E.V. Browell, L.S. Warren, and C.H. Hudgins, Amazon Basin ozone and aerosol: Wet season observations, J. Geophys. Res., 95, 16,903-16,912, 1990e.

Gregory, G.L., B.E. Anderson, L.S. Warren, E.V. Browell, D.R. Bagwell, and C.H. Hudgins, Tropospheric ozone and aerosol observations: The Alaskan Arctic, J. Geophys. Res., 97, 16,451-16,471, 1992.

Gregory, G.L., H.E. Fuelberg, S.P. Longmore, B.E. Anderson, J.E. Collins, and D.R. Blake, Chemical characteristics of tropospheric air over the tropical South Atlantic Ocean: Relationship to trajectory history, J. Geophys. Res., 101, 23,957-23,972, 1996.

Guenther, A., et al., A global model of natural volatile organic compound emissions, J. Geophys. Res., 100, 88738892, 1995.

Hack, J.J., Parameterization of moist convection in the NCAR community climate model (CCM2), J. Geophys. Res., 99, 5551-5568, 1994.

Hack, J.J., B.A. Boville, B.P. Briegleb, J.T. Kiehl, P.J. Rasch, and D.L. Williamson, Description of the NCAR Community Climate Model (CCM2), NCAR Tech. Note $N C A R / T N-382+S T R$, Natl. Cent. for Atmos. Res., Boulder, Colo., 1993.

Harriss, R.C., et al., The Amazon Boundary Layer Experiment (ABLE 2A): Dry season 1985, J. Geophys. Res., 93, 1351-1360, 1988

Harriss, R.C., et al., The Amazon Boundary Layer Experiment: Wet season 1987, J. Geophys. Res., 95, 16,721$16,736,1990 \mathrm{a}$.

Harriss, R.C., G.W. Sachse, G.F. Hill, L.O. Wade, and G.L. Gregory, Carbon monoxide over the Amazon Basin during the wet season, J. Geophys. Res., 95, 16,927-16,932, $1990 \mathrm{~b}$.

Harriss, R.C., et al., The Arctic Boundary Layer Expedition (ABLE 3A): July-August 1988, J. Geophys. Res., $97,16,383-16,394,1992 \mathrm{a}$.

Harriss, R.C., G.W. Sachse, G.F. Hill, L. Wade, K.B. Bartlett, J.E Collins, L.P Steele, and P.C. Novelli, Carbon monoxide and methane in the North American Arcitic and subarctic troposphere: July-August 1988, J. Geophys. Res., 97, 16,589-16,599, 1992b.

Harriss, R.C., S C. Wofsy, J.M. Hoell Jr, R.J. Bendura, J.W. Drewry, R.J. McNeal, D. Pierce, V. Rabine, and R.L. Snell, The Arctic Boundary Layer Expedition (ABLE 3B): July-August 1990, J. Geophys. Res., 99, 1635-1644, $1994 \mathrm{a}$.

Harriss, R.C., G.W. Sachse, J.E. Collins Jr., L. Wade, K B. Bartlett, R.B Talbot, E.V. Browell, L.A. Barrie, G.F. Hill, and L.G. Burney, Carbon monoxide and methane over Canada: July-August 1990, J. Geophys. Res., 99, 1659-1669, 1994b.

Hauglustaine, D.A., G.P. Brasseur, S. Walters, P.J. Rasch, J.-F. Müller, L.K. Emmons, and M.A. Carroll, MOZART: A global chemical transport model for ozone and related chemical tracers, 2, Model results and evaluation, J. Geophys. Res., 103, 28,291-28,335, 1998.

Hauglustaine, D.A., S. Madronich, B.A. Ridley, S.J. Flocke, C.A. Cantrell, F.L. Eisele, R.E. Shetter, D.J. Tanner, P. Ginoux, and E.L. Atlas, Photochemistry and budget of ozone during the Mauna Loa Observatory Photochemistry Experiment (MLOPEX 2), J. Geophys. Res., 104, 30,27530,307, 1999.

Heikes, B., M. Lee, D. Jacob, R. Talbot, J. Bradshaw, H. Singh, D. Blake, B. Anderson, H. Fuelberg, and A.M. Thompson, Ozone, hydroperoxides, oxides of nitrogen, and hydrocarbon budgets in the marine boundary layer over the South Atlantic, J. Geophys. Res., 101, 24,22124,234, 1996.

Hoell, J.M., Jr., G.L. Gregory, D.S. McDougal, A.L. Tor- res, D.D. Davis, J. Bradshaw, M.O. Rodgers, B.A. Ridley, and M.A. Carroll, Airborne intercomparison of nitric oxide measurement techniques, J. Geophys. Res., 92, 1995-2008, 1987a.

Hoell, J.M., Jr., G.L. Gregory, D.S. McDougal, G.W. Sachse, G.F. Hill, E.P. Condon, and R.A. Rasmussen, Airborne intercomparison of carbon monoxide measurement techniques, J. Geophys. Res., 92, 2009-2019, 1987b.

Hoell, J.M., Jr., D.L. Albritton, G.L. Gregory, R.J. McNeal, S.M. Beck, R.J. Bendura, and J.W. Drewry, Operational overview of NASA GTE/CITE-2 airborne instrument intercomparisons: Nitrogen dioxide, nitric acid, and peroxyacetyl nitrate, J. Geophys. Res., 95, 10,047-10,054, 1990.

Hoell, J.M., Jr., et al., Operational overview of NASA GTE/CITE-3 airborne instrument intercomparisons for sulfur dioxide, hydrogen sulfide, carbonyl sulfide, dimethyl sulfide, and carbon disulfide, J. Geophys. Res., 98, 23,291-23,304, 1993.

Hoell, J.M., D.D. Davis, S.C. Liu, R. Newell, M. Shipham, H. Akimoto, R.J. McNeal, R.J. Bendura, and J.W. Drewry, Pacific Exploratory Mission-West A (PEM-West A): September-October 1991, J. Geophys. Res., 101, 1641-1653, 1996.

Hoell, J.M., D.D. Davis, S.C. Liu, R.E. Newell, H. Akimoto, R.J. McNeal, and R.J. Bendura, Pacific Exploratory Mission-West Phase B: February-March, 1994, J. Geophys. Res., 102, 28,223-28,239, 1997.

Hoell, J.M., D.D. Davis, D.J. Jacob, M.O. Rodgers, R.E. Newell, H.E. Fuelberg, R.J. McNeal, J.L. Raper, and R.J. Bendura, The Pacific Exploratory Mission in the tropical Pacific: PEM-Tropics A, August-September, 1996, J. Geophys. Res., 104, 5567-5583, 1999.

Holtslag, A, and B. Boville, Local versus nonlocal boundary-layer diffusion in a global climate model, $J$. Clim., 6, 1825-1842, 1993.

Hudson, R.D., and A.M. Thompson, Tropical tropospheric ozone from total ozone mapping spectrometer by a modified residual method, J. Geophys. Res., 103, 22,129$22,145,1998$

Jacob, D.J., et al., Origin of ozone and $\mathrm{NO}_{x}$ in the tropical troposphere: A photochemical analysis of aircraft observations over the South Atlantic basin, J. Geophys. Res., $101,24,235-24,250,1996$.

Jacob, D.J., J.A. Logan, and P.P. Murti, Effect of rising Asian emissions on surface ozone in the United States, Geophys. Res. Lett., 26, 2175-2178, 1999.

Jaeglé, L., D.J. Jacob, Y. Wang, A.J. Weinheimer, B.A. Ridley, T.L. Campos, G.W. Sachse, and D.E. Hagen, Sources and chemistry of $\mathrm{NO}_{x}$ in the upper troposphere over the United States, Geophys. Res. Lett., 25, 1705-1708, 1998.

Japan Meteorological Agency, Antarctic meteorological data obtained by the Japanese Antarctic Research Expedition, vol. 6, Summary of metorological observations at Syowa, Mizuho, and Asuka Stations 1961-1993, Tokyo, 1995.

Jonquières, I., and A. Marenco, Redistribution by deep convection and long-range transport of $\mathrm{CO}$ and $\mathrm{CH}_{4}$ emissions from the Amazon basin, as observed by the airborne campaign TROPOZ II during the wet season, J. Geophys. Res., 103, 19,075-19,091, 1998.

Jonquières, I., A. Marenco, A. Maalej, and F. Rohrer, Study of ozone formation and transatlantic transport from biomass burning emissions over West Africa during the airborne Tropospheric Ozone Campaigns TROPOZ I and TROPOZ II, J. Geophys. Res., 103, 19,059-19,073, 1998.

Kok, G.L., A.S.H. Prévôt, and R.D. Schillawski, Carbon monoxide measurements from $76^{\circ} \mathrm{N}$ to $59^{\circ} \mathrm{S}$ and over the South Tasman Sea, J. Geophys. Res., 103, 16,731-16,736, 1998.

Kondo Y., T. Kitada, M. Koike, S. Kawakami, and Y. 
Makino, Nitric oxide and ozone in the free troposphere over the western Pacific Ocean, J. Geophys. Res., 98, 20,527-20,535, 1993.

Law, K.S., P.-H. Plantevin, V. Thouret, A. Marenco, W.A.H. Asman, M. Lawrence, P.J. Crutzen, J.-F. Muller, D. Hauglustaine, and M. Kanakidou, Comparison between global chemistry transport model results and Measurement of Ozone and Water Vapor by Airbus In-Service Aircraft (MOZAIC) data, J. Geophys. Res., 105, 1503$1525,2000$.

Lee, M., B.G. Heikes, and D.J. Jacob, Enhancements of hydroperoxides and formaldehyde in biomass burning impacted air and their effect on atmospheric oxidant cycles, J. Geophys. Res., 103, 13,201-13,212, 1998.

Logan, J.A., An analysis of ozonesonde data for the troposphere: Recommendations for testing 3-D models, and development of a gridded climatology for tropospheric ozone, J. Geophys. Res., 104, 16,115-16,149, 1999.

Marenco, A., and F. Said, Meridional and vertical ozone distribution in the background troposphere $\left(70^{\circ} \mathrm{N}-60^{\circ} \mathrm{S}\right.$; 0-12 km altitude) from scientific aircraft measurements during the STRATOZ III experiment (June 1984), Atmos. Environ., 23, 201-214, 1989.

Marenco, A., M. Macaigne, and S. Prieur, Meridional and vertical $\mathrm{CO}$ and $\mathrm{CH}_{4}$ distributions in the background troposphere $\left(70^{\circ} \mathrm{N}-60^{\circ} \mathrm{S} ; 0-12 \mathrm{~km}\right.$ altitude) from scientific aircraft measurements during the STRATOZ III experiment (June 1984), Atmos. Environ., 23, 185-200, 1989.

Marenco, A., C. Medale and S. Prieur, Study of tropospheric ozone in the tropical belt (Africa, America) from STRATOZ and TROPOZ campaigns, Atmos. Environ., Part A, 24, 2823-2834, 1990.

Marenco, A., I. Jonquières, H. Gouget, and P. Nédélec, Experimental determinations of meridional distribution and long term evolution of tropospheric ozone - Consequences on radiative forcing, in Atmospheric Ozone as a Climate Gas, edited by W C. Wang and I S.A Isaksen, pp. 305319 , Springer, New York, 1995.

Marenco, A., et al., Measurement of ozone and water vapor by Airbus in-service aircraft: The MOZAIC airborne program, An overview, J. Geophys. Res., 103, 25,631-25,642, 1998.

Matsubara, K., M. Doi, T. Uekubo, K. Okada, S. Aoki, and $\mathrm{S}$. Kawaguchi, Results of ozone observation from the equatorial region to Antarctica in 1987, Proc. NIPR Symp. Polar Meteorol. Glaciol., 4, 1-11, 1991.

Matsueda, H., H. Inoue, Y. Sawa, and Y. Tsutsumi, Carbon monoxide in the upper troposphere over the western Pacific between 1993 and 1996, J. Geophys. Res., 103, 19,093-19,110, 1998.

Merrill, J.T., R.E. Newell, and A.S. Bachmeier, A climatological overview for the Pacific Exploratory Mission-West Phase B, J. Geophys. Res., 102, 28,241-28,253, 1997.

Müller, J.-F., Geographical distribution and seasonal variation of surface emissions and deposition velocities of atmospheric trace gases, J. Geophys. Res., 97, 3787-3804, 1992 .

Müller, J.-F., and G. Brasseur, IMAGES: A threedimensional chemical transport model of the global troposphere, J. Geophys. Res., 100, 16,445-16,490, 1995.

Müller, J.-F., and G. Brasseur, Sources of upper tropospheric $\mathrm{HO}_{x}$ : A three-dimensional study, J. Geophys. Res., 104, 1705-1715, 1999.

O'Sullivan, D.W., B.G. Heikes, M. Lee, W. Chang, G.L. Gregory, D.R. Blake, and G.W. Sachse, The distribution of hydrogen peroxide and methylhydroperoxide over the Pacific and South Atlantic Oceans, J. Geophys. Res., 104, 5635-5646, 1999.

Penkett, S.A., and K.A. Brice, The spring maximum in photo-oxidants in the northern hemisphere troposphere, Nature, 319, 655-657, 1986.

Perros, P.E., Large-scale distribution of hydrogen peroxide from aircraft measurements during the TROPOZ II experiment, Atmos. Environ., Part A, 27, 1695-1708, 1993.

Perros, P.E., Large-scale distribution of peroxyacetylnitrate from aircraft measurements during the TROPOZ II experiment, J. Geophys. Res., 99, 8269-8279, 1994.

Pham, M., J.-F. Müller, G. Brasseur, C. Granier, and G. Megie, A three-dimensional study of the tropospheric sulfur cycle, J. Geophys. Res., 100, 26,061-26,092, 1995.

Pickering, K.E., Y. Wang, W.-K. Tao, C. Price, and J.-F. Müller, Vertical distributions of lightning $\mathrm{NO}_{x}$ for use in regional and global chemical transport models, J. Geophys. Res., 103, 31,203-31,216, 1998.

Price, C., J. Penner, and M. Prather, $\mathrm{NO}_{x}$ from lightning, 1 , Global distribution based on lightning physics, J. Geophys. Res., 102, 5929-5941, 1997

Ridley, B A, M.A. Carroll, and G L. Gregory, Measurements of nitric oxide in the boundary layer and free troposphere over the Pacific Ocean, J. Geophys. Res., 92, 2025-2047, 1987.

Ridley, B.A., M.A. Carroll, G.L. Gregory, and G.W. Sachse, $\mathrm{NO}$ and $\mathrm{NO}_{2}$ in the troposphere: Technique and measurements in regions of a folded tropopause, J. Geophys. Res., 93, 15,813-15,830, 1988.

Ridley, B.A., et al., Ratios of peroxyacetyl nitrate to active nitrogen observed during aircraft flights over the eastern Pacific Ocean and continental United States, J. Geophys. Res., 95, 10,179-10,192, 1990.

Ridley, B.A., J G. Walega, J.E. Dye, and F.E. Grahek, Distributions of $\mathrm{NO}, \mathrm{NO}_{x}, \mathrm{NO}_{y}$, and $\mathrm{O}_{3}$ to $12 \mathrm{~km}$ altitude during the summer monsoon season over New Mexico, $J$. Geophys. Res., 99, 25,519-25,534, 1994.

Ridley, B A, E L. Atlas, J.G. Walega, G L Kok, T.A Staffelbach, J.P. Greenberg, F.E. Grahek, P.G. Hess, and D.D. Montzka, Aircraft measurements made during the spring maximum of ozone over Hawaii: Peroxides, CO, $\mathrm{O}_{3}, \mathrm{NO}_{y}$, condensation nuclei, selected hydrocarbons, halocarbons, and alkyl nitrates between 0.5 and $9 \mathrm{~km}$ altitude, J. Geophys. Res., 102, 18,935-18,961, 1997.

Rohrer, F., D. Brüning, and D.H. Ehhalt, Tropospheric mixing ratios of NO obtained during TROPOZ II in the latitude region $67^{\circ} \mathrm{N}-56^{\circ} \mathrm{S}, J$. Geophys. Res., 102, 25,42925,449, 1997.

Ruggaber, A., R. Dlugi, and T. Nakajima, Modelling radiation quantities and photolysis frequencies in the troposphere, J. Atmos. Chem., 18, 171-210, 1994.

Sachse, G.W., R.C. Harriss, J. Fishman, G.F. Hill, and D.R. Cahoon, Carbon monoxide over the Amazon Basin during the 1985 dry season, J. Geophys. Res., 93, 1422-1430, 1988.

Sandholm, S., et al., Summertime tropospheric observations related to $\mathrm{N}_{x} \mathrm{O}_{y}$ distributions and partitioning over Alaska: Arctic Boundary Layer Expedition 3A, J. Geophys. Res., 97, 16,481-16,509, 1992.

Sandholm, S., et al., Summertime partitioning and budget of $\mathrm{NO}_{y}$ compounds in the troposphere over Alaska and Canada: ABLE 3B, J. Geophys. Res., 99, 1837-1861, 1994.

Schultz, M., et al., On the origin of tropospheric ozone and $\mathrm{NO}_{x}$ over the tropical South Pacific, J. Geophys. Res., $104,5829-5843,1999$.

Shipham, M.C., A.S. Bachmeier, D.R. Cahoon Jr., and E.V. Browell, Meteorological overview of the Arctic Boundary Layer Expedition (ABLE 3A) flight series, J. Geophys. Res., 97, 16,395-16,419, 1992.

Shipham, M.C., A.S. Bachmeier, D.R. Cahoon Jr, G.L. Gregory., B.E. Anderson, and E.V. Browell, A meteorological 
interpretation of the Arctic Boundary Layer Expedition (ABLE) 3B flight series, J. Geophys. Res., 99, 1645-1657, 1994 .

Singh, H.B., D. Herlth, D. O'Hara, L. Salas, A.L. Torres, G.L. Gregory, G.W. Sachse, and J.F. Kasting, Atmospheric peroxyacetyl nitrate measurements over the Brazilian Amazon Basin during the wet season: Relationships with nitrogen oxides and ozone, J. Geophys. Res., 95, 16,945-16,954, 1990a.

Singh, H.B., et al., Peroxyacetyl nitrate measurements during CITE 2: Atmospheric distribution and precursor relationships, J. Geophys. Res., 95, 10,163-10,178, $1990 \mathrm{~b}$.

Singh, H.B., et al., Atmospheric measurements of peroxyacetyl nitrate and other organic nitrates at high latitudes: Possible sources and sinks, J. Geophys. Res., 97, 16,511$16,522,1992$

Singh, H.B., et al., Summertime distribution of PAN and other reactive nitrogen species in the northern highlatitude atmosphere of eastern Canada, J. Geophys. Res., 99, 1821-1835, 1994a.

Singh, H.B., D. O'Hara, D. Herlth, G.W. Sachse, D.R. Blake, J.D. Bradshaw, M. Kanakidou, and P.J. Crutzen, Acetone in the atmosphere: Distribution, sources, and sinks, J. Geophys. Res., 99, 1805-1819, 1994b.

Singh, H.B., M. Kanakidou, P.J. Crutzen, and D.J. Jacob, High concentrations and photochemical fate of oxygenated hydrocarbons in the global troposphere, Nature, 378, 50-54, 1995.

Singh, H.B., et al., Latitudinal distribution of reactive nitrogen in the free troposphere over the Pacific Ocean in late winter/early spring, J. Geophys. Res., 103, 28,237-28,246, 1998.

Smyth, S.B., et al., Factors influencing the upper free tropospheric distribution of reactive nitrogen over the South Atlantic during the TRACE-A experiment, J. Geophys. Res., 101, 24,165-24,186, 1996.

Staffelbach, T.A., G.L. Kok, B.G. Heikes, B. McCully, G.I. Mackay, D.R. Karecki, and H.I. Schiff, Comparison of hydroperoxide measurements made during the Mauna Loa Observatory Photochemistry Experiment 2, J. Geophys. Res., 101, 14,729-14,739, 1996.

Talbot, R.W., et al., Summertime distribution and relations of reactive odd nitrogen species and $\mathrm{NO}_{y}$ in the troposphere over Canada, J. Geophys. Res., 99, 1863-1885, 1994.

Thakur, A.N., H.B. Singh, P. Mariani, Y. Chen, Y. Wang, D.J. Jacob, G. Brasseur, J.-F. Müller, and M. Lawrence, Distribution of reactive nitrogen species in the remote free troposphere: Data and model comparisons, Atmos. Environ., 33, 1403-1422, 1999.

Thouret, V., A. Marenco, P. Nédélec, and C. Grouhel, Climatologies at 9-12 km altitude as seen by the MOZAIC airborne program between September 1994 and August 1996, J. Geophys. Res., 103, 25,653-25,679, 1998.

Toon, O. B., and R. C. Miake-Lye, Subsonic Aircraft: Contrail and Cloud Effects Special Study (SUCCESS), Geophys. Res. Lett., 25, 1109-1112, 1998.

Torres, A.L., and H. Buchan, Tropospheric nitric oxide measurements over the Amazon Basin, J. Geophys. Res., 93, 1396-1406, 1988.
Turco, R., A. Plumb, and E. Condon, The Airborne Arctic Stratospheric Expedition: Prologue, Geophys. Res. Lett., 17, 313-316, 1990.

Wang, Y., J.A. Logan, and D.J. Jacob, Global simulation of tropospheric $\mathrm{O}_{3}-\mathrm{NO}_{x}$-hydrocarbon chemistry, 2, Model evaluation and global ozone budget, J. Geophys. Res. $103,10,727-10,755,1998$

Weinheimer, A.J., J.G. Walega, B.A. Ridley, G.W. Sachse B.E. Anderson, and J.E. Collins Jr., Stratospheric $\mathrm{NO}_{y}$ measurements on the NASA DC-8 during AASE II, Geophys. Res. Lett., 20, 2563-2566, 1993.

Wennberg, P.O., et al., Hydrogen radicals, nitrogen radicals, and the production of $\mathrm{O}_{3}$ in the upper troposphere, Science, 279, 49-53, 1998.

Williamson, D.L., and P. Rasch, Water vapor transport in the NCAR CCM2, Tellus, 46, 34-51, 1994.

Wofsy, S.C., R.C. Cohen, and A.L. Schmeltekopf, Overview: The Stratospheric Photochemistry Aerosols and Dynamics Expedition (SPADE) and Airborne Arctic Stratospheric Expedition II (AASE-II), Geophys. Res. Lett., 21, 2535-2538, 1994.

Yienger, J.J., and H. Levy II, Empirical model of global soilbiogenic $\mathrm{NO}_{x}$ emissions, J. Geophys. Res., 100, 11,447$11,464,1995$.

Yienger, J.J., A.A. Klonecki, H. Levy II, W.J. Moxim, and G.R. Carmichael, An evaluation of chemistry's role in the winter-spring ozone maximum found in the northern midlatitude free troposphere, J. Geophys. Res., 104, 36553667, 1999.

Ziemke, J.R., S. Chandra, and P.K. Bhartia, Two new methods for deriving tropospheric column ozone from TOMS measurements: Assimilated UARS MLS/HALOE and convective-cloud differential techniques, J. Geophys. Res., 103, 22,115-22,127, 1998.

G. Brasseur, Max Planck Institute for Meteorology, Bundestrasse, 55, 20146 Hamburg, Germany. (brasseur@dkrz.de)

D. Brunner and J. Staehelin, Institute for Atmospheric Science, Swiss Federal Institute of Technology, ETH Hoenggerberg HPP, CH-8093 Zurich, Switzerland.

M. A. Carroll, Department of Atmospheric, Oceanic and Space Sciences, University of Michigan, 2455 Hayward, Ann Arbor, MI 48109-2143. (mcarroll@umich.edu)

L. Emmons, Atmospheric Chemistry Division, National Center for Atmospheric Research, P.O. Box 3000, Boulder, CO 80307. (emmons@ucar.edu)

D. Hauglustaine, CNRS Service d'Aéronomie, Université de Paris 6, Tour 15 Couloir 15-14, 4 Place Jussieu, F-75252 Paris Cedex 05, France. (dh@aero.jussieu.fr)

J.-F. Müller, Belgian Institute for Space Aeronomy, B1180 Brussels, Belgium. (jfm@oma.be)

A. Marenco and V. Thouret, Laboratoire d'Aérologie, UMR CNRS/UPS 5560, O.M.P., 14 Avenue Edouard Belin, 31400 Toulouse, France.

(Received November 19, 1999; revised April 5, 2000; accepted April 12, 2000.) 